\title{
Nature as Inspiration for Space Optimization and Products Multifunctionality
}

\author{
Nikola Gerasimovski
}

Faculty of Mechanical Engineering, Industrial Design, Ss. "Cyril and Methodius University" of Skopje, Skopje, Republic of Macedonia

\begin{abstract}
Citation: Gerasimovski N. [Nature as Inspiration for Archit Des. 2018 Jun 20; 10036. [MSc] [Macedonian] http://dx.doi.org/10.3889/seejad.2018.10036

Keywords: Multufunctionality; Space optimization; ature; Bionic; Backpakt; Ergonomy

"Correspondence: Nikola Gerasimovski. Faculty of (Cyril and Methodius University" of Skopje, Skopje, Republic of Macedonia. E-mail: gerasimovskinikola@yahoo.com

Received: 06-Aug-2018; Revised: 11-Aug-2018; 2018; Published: 22-Aug-2018

Copyright: ๑ 2018 Nikola Gerasimovski. This is an openaccess article distributed under the terms of the Creative use, distribution, and reproduction in any medium, provided the original author and source are credited.

Competing Interests: The author has declared that no competing interests exist
\end{abstract}

\section{Abstract}

The main goal in this master thesis is to find efficient ways for providing multi-functionality and space optimization of products by exploring and applying modern bionic and design principles. The specific design issue that needed to be addressed was - design of a multifunctional mountain hiking backpack that allows optimal use of space and maximal comfort when being used. An ideal solution to this stated problem was accomplished by following several phases in the process: study of available literature in the areas of multifunctionality, adaptability and product optimization; analysis of bionic phenomena which were the basic inspiration for creating a modular and compact design; detailed analysis of ergonomic aspects and anthropometric measures; analysis of the target group and the market; analysis of materials; development of design solutions and selection of the most suitable concept according to its strongest fulfilment of the given design requirements; elaboration of the final concept and its evaluation. 
Универзитет Свети Кирил и Методиј

Машински фракултет - Скопје

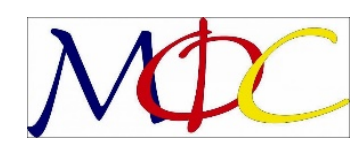

\title{
ПРИРОДАТА КАКО ИНСПИРАЦИЈА ЗА ОПТИМИЗАЦИЈА НА ПРОСТОРОТ И МУЛТИФУНКЦИОНАЛНОСТ НА ПРОИЗВОДИТЕ
}

\author{
Магистерска работа \\ Изработил: Никола Герасимовски \\ Ментор: Профр. д-р Софрија Сидоренко
}

Постдипломски студии - Индустриски дизајн и маркетиниг

Скопје 2018 
Ментор:

Членови на комисијата:

Дата на одбрана:

Дата на промоција:
Профр.д-р Софрија Сидоренко

Машински фракултет - Скопје

Профр.д-р Софија Сидоренко

Машински фракултет - Скопје

Проф.д-р Татјана Кандикјан

Машински фракултет - Скопје

Проф.д-р Јасмина Чалоска

Машински фракултет - Скопје 
Никола Герасимовски

\title{
ПРИРОДАТА КАКО ИНСПИРАЦИЈА ЗА ОПТИМИЗАЦИЈА НА ПРОСТОРОТ И МУЛТИФУНКЦИОНАЛНОСТ НА ПРОИЗВОДИТЕ
}

\begin{abstract}
Апстракт
Главна цел на овој магистерски труд е преку истражување и примена на современите бионички методи и принципи на дизајнирање да се изнајдат ефикасни начини за обезбедување мултифункционалност и оптимизација на просторот кај производите. Конкретниот дизајнерски проблем за кој беше потребна анализа на споменатите принципи е креацијата на мултифункционален ранец за планинарење, кој овозможува оптимално искористување на просторот и максимална удобност при негова употреба. Добивање идеално решение на овој проблем беше постигнато низ неколку фрази: проучување на расположлива литература од областите на мултифункционалност, адаптибилност и оптимизација на просторот кај производите; анализа на бионички феномени кои беа основна инспирација за креирање модуларен и компактен дизајн; детална анализа на ергономските аспекти и антропометриски мерки; анализа на целната група и пазарот; анализа на материјали; разработка на идејни решенија и избор на најсоодветен концепт според најсилно задоволување на зададените дизајнерски барања; разработка на финалниот концепт и негова евалуација.
\end{abstract}

Клучни зборови: мултифункционалност, оптимизација на простор, бионика, ранец, ергономија 


\title{
Nikola Gerasimovski
}

\section{NATURE AS INSPIRATION FOR SPACE OPTIMIZATION AND PRODUCTS MULTIFUNCTIONALITY}

\begin{abstract}
The main goal in this master thesis is to find efficient ways for providing multi-functionality and space optimization of products by exploring and applying modern bionic and design principles. The specific design issue that needed to be addressed was - design of a multifunctional mountain hiking backpack that allows optimal use of space and maximal comfort when being used. An ideal solution to this stated problem was accomplished by following several phases in the process: study of available literature in the areas of multifunctionality, adaptability and product optimization; analysis of bionic phenomena which were the basic inspiration for creating a modular and compact design; detailed analysis of ergonomic aspects and anthropometric measures; analysis of the target group and the market; analysis of materials; development of design solutions and selection of the most suitable concept according to its strongest fulfillment of the given design requirements; elaboration of the final concept and its evaluation.
\end{abstract}

Key words: multufunctionality, space optimisation, nature, bionic, backpakt, ergonomy 


\section{СОДРЖИНА}

1. Вовед

2. Истражување на научни достигнувања од областа на мултифункционалноста и оптимизација на просторот во дизајнот на производи

3. Потрага по примери од природата за кои се карактеристични мултифункционалноста и оптимизација на просторот

3.1 Усвојување на бионичка стратегија

3.1.1 Дизајн брифинг и дефинирање на проблемот 5

3.1.2 Реформулирање на проблемот 6

3.1.3 Избор на решенија 6

$\begin{array}{ll}3.1 .4 & \text { Анализа на решенијата } \\ \end{array}$

3.1.4.1 Поголем простор за складирање, заштеда на простор и мала тежина 7

3.1.4.2 Потреба од енергија 9

3.1.4.3 Помошни механизми за движење и носење на товар (ЕГЗОСКЕЛЕТ) 9

3.1.4.4 Трансформирање на телото за добивање на дополнителна функција 10

3.1.4.5 Менување на големината 11

3.1.4.6 Заштита од атмосферски влијанија $\quad 12$

3.2 Заклучоци од извршените бионички истражувања и поставување на хипотези 12

4. Дефинирање на дизајнерски проблем - мултифункционален ранец за планинарење 14

4.1 Постоечки производи за носење планинарска опрема - РАНЦИ

5. Ергономски истражувања поврзани со носење ранци 21

5.1 Ергономски правила во врска со носење на ранец 21

5.2 Избор на соодветна големина на ранец 21

5.2.1 Начин на пакување и распоредување на товарот 22

5.2.2 Неправилно пакување 23

5.2.3 Дизајн на заден дел на ранец 23

6. Нови технологии кои можат да дадат придонес во решавање на зададените дизајнерски цели 25

6.1 ИНОВАЦИЈА ЕXOSKELET 26

6.2 МАТЕРИЈАЛИ 27

6.2.1 ПОЛИЕТИЛЕН 29

6.2.2 ПЛАТНО 31

6.2.3 CURV 33

6.2.4 Соларни ќелии 34

6.2.5 Термоформирање 35

7. АНАЛИЗА НА ПАЗАРОТ 36

7.1 АНАЛИЗА НА ПОСТОЕЧКИ ПРОИЗВОДИ НА ПАЗАРОТ 36

7.2 Некомерцијална употреба 36 
$\begin{array}{lll}\text { 7.2.1 } & \text { EXO HIKER } & 36\end{array}$

$\begin{array}{lll}\text { 7.2.2 } & \text { ERGONOMY PACKS } & 38\end{array}$

7.2.3 ELECTRICITY GENERATING BACKPACK 39

7.3 КОМЕРЦИЈАЛНА УПОТРЕБА

7.3.1 HMG 2400 \& 3400 Southwest $\quad 40$

$\begin{array}{lll}\text { 7.3.2 } & \text { Gossamer Gear Gorilla } 40 & 40\end{array}$

7.3.3 ZPacks Arc Blast $\quad 41$

$\begin{array}{lll}\text { 7.3.4 DEUTER } & 41\end{array}$

7.4 АНАЛИЗА НА КУПУВАЧИТЕ

7.4.1 АНАЛИЗА НА КОРИСНИЧКИТЕ ПОТРЕБИ

8. ГЕНЕРИРАЊЕ НА КОНЦЕПТИ

8.1 КОНЦЕПТ 1245

8.2 КОНЦЕПТ $2 \quad 45$

8.3 КОНЦЕПТ $3 \quad 46$

8.4 ОПИС НА ПРОИЗВОДОТ

8.5 ЕРГОНОМИЈА И АНТРОПОМЕТРИЈА

8.6 ИЗРАБОТКА

9. ЗАКЛУЧОК 60

ПРИЛОГ А

ПРИЛОГ Б 


\section{1. ВОВЕД}

Современите методи и пристапи во дизајнот овозможуваат креирање на иновативни дизајнерски решенија на најразлични производи со кои се олеснува и унапредува човековиот живот во сите сфрери на современото живеење. Проучувањето на универзалните принципи во дизајнот, ергономските и бионичките методи, како и најновите дизајнерски стратегии го унапредуваат процесот на дизајнирање.

Главна цел на овој магистерски труд е да се проучат современите методи и принципи на дизајнирање за да се изнајдат соодветни ефикасни начини за обезбедување мултифункционалност и оптимизација на просторот кај производите.

Истражувањето во овој магистерски труд се одвиваше во неколку фази. Првата фаза беше посветена на теоретска анализа, т.е. проучување на расположливата литература и научни трудови од области на мултифункционалност, адаптибилност и оптимизација на просторот кај производите.

Во втората фраза беше извршено бионичко истражување. Со примена на бионичката методологија беше направена анализа на постоечки примери од природата кои обезбедија доволно аргументи за поставување на неколку хипотези, посветени на постапките кои можат да обезбедат решавање на поставените цели мултифункционалност и оптимизација на просторот кај производите.

За експериментална потврда на поставените хипотези, во оваа фаза беше зададен конкретен дизајнерски проблем - дизајн на мултифункционален ранец за планинарење, кој треба да овозможи оптимално искористување на просторот и сместување на сите неопходни парчиња опрема за планинарење.

Во третата фраза е извршено истражување на пазарот и издвоени се неколку карактеристични производители на ранци и планинарска опрема.Извршена е споредба помеѓу најдобрите производи од оваа категорија и нивните карактеристики, извлечени се корисни заклучоци. Извршена е анализа и разгледување на веќе реализирани анкети за овој тип на производи и коментари од реални корисници на социјалните мрежи и форуми, со цел да се утврди што е најпотребно. Преку квантитивни и квалитативни анализи на засегната таргет група (планинари) извлечени се важни заклучоци и прецизни барања во врска со поставената дизајнерска цел.

Четвртата фраза беше посветена на дополнителни истражувања неопходни за што подобар пристап во решавањето на поставената задача. 
Беше извршена анализа на научни трудови од областа на ергономијата на користење ранци, поточно носење товари на грб, ограничувања во зависност од физичката структура на корисникот итн. Овие истражувања имаа за цел да се обезбедат сите неопходни информации за правилно утврдување на димензиите на производот и обезбедување поголема удобност на р'бетот. Во истата фаза беа проучени најнови сознанија и достигнувања во областа на материјалите, алтернативни извори на енергија итн.

Во петтата фраза е извршено точно дефинирање на барањата во врска со поставениот дизајнерски проблем. Врз база на истражување на бионичките форми, примери од природата, беше обезбедена инспирација за максимално искористување и организирање на просторот, модуларните карактеристики на одредени вградени компоненти во ранецот, а истовремено адаптибилност и мултифунционалност. Како резултат на извршените бионички проучувања произлегоа неколку концепти - можни решенија. Избор на најдобриот концепт е извршен преку оценување во однос степенот на исполнување на неколку важни и пресудни критериуми: ергономија, дизајн, модуларност, едноставност, волумен, тежина, адаптибилност. Избраниот концепт беше детално разработен преку компјутерски 3D модел со задавање материјали, детална визуелизација, анимација, заклучно со реален модел.

На крајот од ова истражување извршена е евалуација на резултатите, при што е заклучено дека поставените хипотези се потврдени. Со нивна примена е реализиран цел еден процес на дизајнирање во кој се постигнати поставените цели. Уште повеќе, постапките и чекорите применети во овој процесот на дизајнирање можат да бидат понатаму применети како насоки при дизајнирањето производи кај кои мултифункционалноста и оптимизацијата на просторот е од пресудно значење. 


\section{2. ИСТРАЖУВАЊЕ НА НАУЧНИ ДОСТИГНУВАҢА ОД ОБЛАСТА НА МУЛТИФУНКЦИОНАЛНОСТА И ОПТИМИЗАЦИЈА НА ПРОСТОРОТ ВО ДИЗАЈНОТ НА ПРОИЗВОДИ}

Дизајнерските методологии се есенцијална алатка во процесот на дизајн кои обезбедуваат насоки, цели и техничка подршка за развој на нови производи. Исто така го скратуваат времето и ги намалуваат ризиците од процесот на развој на производи. Ако се користат дизајн методите за развој на нов производ тоа не гарантира успех, бидејќи влијаат огромен број на фактори, вклучувајќи ги техничките екпертизи и креативноста. Тие служат само како помош на дизајнерот да има се под контрола и полесно да донесе одлука како ќе продолжи понатаму. Неопходно е да се прецизираат целите, барањата и ограничувањата за процесот на дизајнирање, како и да се проучат и дефинираат сите можни насоки со цел да се откријат навреме евентуалните причини за неуспех. Насочувањето на корисниците кон исполнување на барањата и соодветно решение на проблемот е цел на секој дизајнерски метод, вклучувајќи го и дизајнерскиот метод со бионички карактер. Планирањето и развојот на производи мора да обезбедат итеративна природа на процесот со константна проценка на процесот на дизајн. Затоа, методите за развој на производи треба да дозволат постојано прилагодување и надградување.

\section{1 Оптимизација на просторот}

Оптимизацијата е процес на обезбедување на најдобар дизајн според зададени критериуми. Оптимизацијата може да се однесува на најмала цена на чинење, најмала потрошувачка на енергија, најмала загуба на енергија, најголем учинок во работата, најдобра искористеност на просторот итн. Често инженерската оптимизација се врши имплицитно. Користејќи комбинација од проценка, искуство, моделирање, мислењата на другите итн. инженерот донесува одлуки за дизајнирање кои тој се надева дека ќе доведат до оптимален дизајн. Меѓутоа, ако постојат многу варијабли кои треба да се прилагодат со неколку спротивставени цели и ограничувања, оптимизацијата базирана на искуства може да не успее да го идентификува оптималниот дизајн. Интеракциите се премногу сложени и варијабилите премногу бројни за интуитивно да го одредат оптималниот дизајн.[1]

Целта на оптимизацијата е да се одредат вредностите на променливите на дизајнот за да се добие екстремна објективна функција која ќе ги задоволува зададените ограничувања. 
Ова се однесува на големината на структурната оптимизација, форма и топологија. Оптимизацијата на големина одредува оптимални особини на секциите, како дебелина или дијаметар. Целта на оптимизацијата на обликот е да се одреди формата на системот, во кој променливите на дизајнот ја претставуваат формата, додека во тополгијата на оптимизацијата, треба да се избере топологија на системот.

Шмит [2] предложил општ пристап кон структурната оптимизација користејќи анализа на 9-тиот елемент и нелинеарно математичко програмирање во 1960 година. Проблемите со големината се само рутина [3; 4]. Франкавила и др. [5] формулирале пристап со кој преку оптимизација на обликот и на фрормата се минимизира концентрацијата на силите врз основа на дискретизирани фоорми. Теоријата на чувствителност на обликот на дизајн анализата сега е добро утврдена од страна на Сеа [6], Zolesio [7], Reousselet [8] и Haug et al. [9].

Мауте и Рамм [10] предложиле оптимизација на адаптивна топологија користејќи интегриран модел. Тие вршеле оптимизација на обликот и оптимизација на топологијата одделно и ги мапирале резултатите одделно за секој од нив со користење на "позадинска мрежа". Тие го промениле дизајнерската шаблон за оптимизација на топологијата користејќи адаптивна мрежна стратегија за редукција. Овој метод предлага повторна употреба за да се откријат нејасните граници на доменот. Структурниот распоред може да се подобри со оваа помалку или повеќе ад хок методологија. Повторна употреба се прави со цел да се минимизира објективната функција, бидејќ индицираната повторна реализација не дава никаква информација за ефективната реакција на целта или ограничувачките функции.

Има многу пристапи за оптимизација, но како најкористен е пристапот со оптимизација на просторот кој има за цел да се оптимизираат функцијата на дизајнот во однос на топологијата, како и вообичаените дизајн варијабли за обликот и големината. Со цел да се промени функцијата на дизајнот, бројот на променливите во дизајнот постепено се зголемува, а тоа одговара на еволуцијата на дизајн просторот од едноставна до софистицирана состојба. Способноста за проширување на дизајн доменот е значајно подобрување во однос на методите за конвенционална топологија, каде што тоа е невозможно. Овој метод обезбедува e-client алатка врз основа на аналитичка анализа на сензитивност користејќи го концептот на просторен дизајн. Новата фрормулација се применува на две категории на структурни оптимизациски проблеми: топологија, оптимизација и проблеми со дистрибуција според дебелина на плоча [11] . 


\section{2 Модуларност на производите}

Денешниот пазар има сѐ поголеми барања, компаниите се принудени да се фокусираат на помали и специфични пазарни сегменти на производи ориентирани кон корисниците. Главниот услов производот да биде прилагодлив е да ја задржи својата чувствителност на промена на најниско можно ниво. Сега во моментот актуелна е ерата на „масовно прилагодување“ (слика 2.1) . Колку повеќе се намалува чувствителноста, толку повеќе се зголемува фрлексибилноста [12] . Затоа, се користат флексибилни дизајн архитектури, со цел да се направат производите лесни, со ниски трошоци за изработка и со можност за брзи промени. Модуларноста е таков тип на архитектура и се смета за најефиксано средство за постигнување на овие барања.

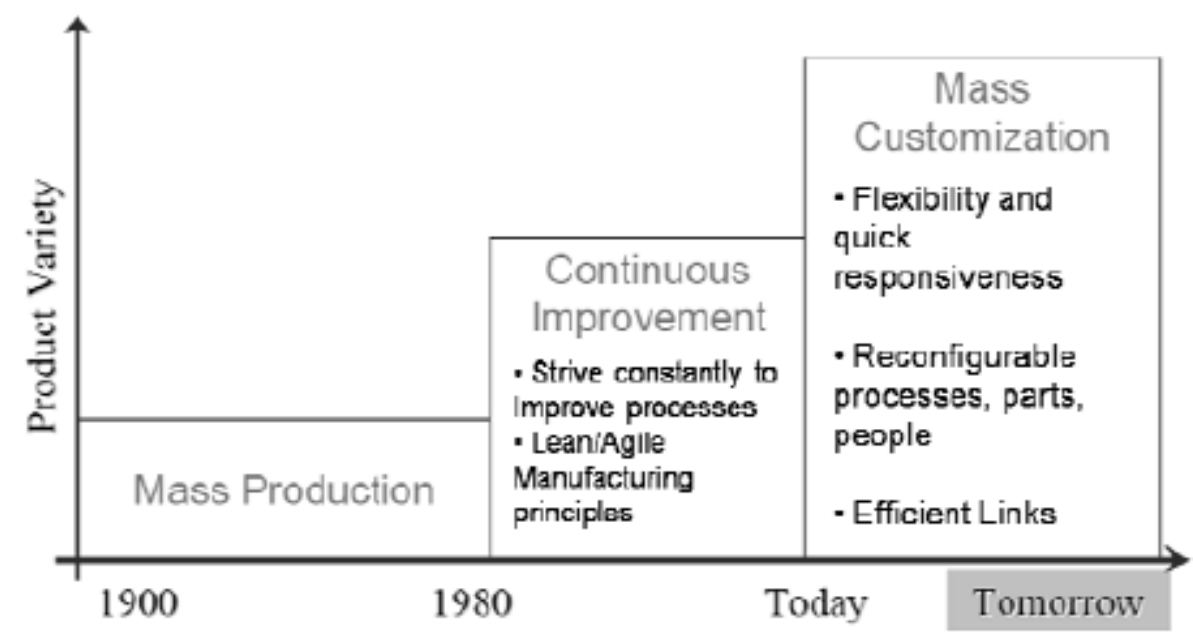

Слика 2.1 Од ера на масовно производство до ера на масовни прилагодувања

Истражувањата користат десиниција на модуларноста базирана не само на обликовната и функционалната структура на еден производ, туку, исто така, и на процесите на животниот циклус, како што се производство, монтажа, сервис и рециклирање. Индустријата прави напори да ги модуларизира производите за да бидат фллексибилни за потребите на крајните корисници.

Улрих [13] прв истакнал две главни архитектури во дизајнот на производи: интегрална и модуларна (табела 2.1). Кај интегралната архитектура, компонентите на производот се дизајнирани за повеќе од една функција и интерфејсите меѓу нив се споени. Во модуларната архитектура, постои поврзување помеѓу функциите и деловите (модулите), а специфираните интерфејси се раздвоени. Сепак, во последните години, модуларноста или интегралноста повеќе не се сметаат за бинарна карактеристика. Затоа, производите може да припаѓаат на една или на друга архитектура во различен степен [14]. 


\begin{tabular}{|c|c|}
\hline \multicolumn{2}{|c|}{ СПОРЕДБА ПОМЕЃУ ИНТЕГРАЛНА И МОДУЛАРНА ДИЗАЛН АРХИТЕКТУРА } \\
\hline ИНТЕГРАЛНА & МОДУЛАРНА \\
\hline Високи системски перформанси & Редуцирани перформанси \\
\hline Ниска цена за голема количина & Ниска цена за мала количина \\
\hline Цврсто поврзани дизајн тимови & Лабава врска помеѓу дизајн тимови \\
\hline Скапи алати, класично производства & Флексибилно производство \\
\hline Тешки можности за промена на & Променливи производи \\
\hline производот & \\
\hline
\end{tabular}

Табела 2.1 Споредба помеѓу интегрална и модуларна дизајн архитектура

Модуларност за животен циклус подразбира поддржување на независноста помеѓу компонентите и сите процеси на животниот циклус во различни модули, поттикнување сличност во сите компоненти и процеси во модулите, како и поддржување заменливост на модулите. Се смета дека модуларната архитектура е најефикасно средство за постигнување на овие барања. Придобивките од модуларноста вклучуваат:

- намалување на цената на чинење по единица производ,

- олеснување на ажурирањето на дизајнот на производите,

- зголемена разновидност на производите,

- намалување на времето на достава,

- олеснување во тестирањето на дизајнот.

Во текот на изминатите години се понудени голем број на методи и алатки за развој на модуларен дизајн. Методите кои најмногу се користат од дизајнерите и инженерите се опишани подолу.

Структурната дизајн матрица (DSM) [15] се користи за подобро претставување на структурата на елементите на системот. Преку визуелизација на објектите, дизајнерот има подобра контрола на модуларноста на производот, со преглед на сложеноста на интерфејсот. Овие матрици се обично бинарни, квадратни и ги содржат елементите на системот.

Теоријата на аксиоматски дизајн (ADT), развиена од Сух [16], е метод кој ги трансформира корисничките атрибути (CAs) во функционални барања (FRs) и потоа до параметрите на дизајнот (DP) и променливи процеси (PVs). Дизајнот станува интеракција помеѓу функционалниот (FR домен) и физичкиот домен (DP домен). 
Функција на модуларно распоредување (Modular Function Deployment MFD) [17] ce разликува од други методи за градба на производите со обезбедување на сеопфатен пристап кој ги зема во предвид барањата на сите засегнати страни во врска со развојот на производот. MFD се состои од пет главни чекори:

1. Дефинирање на барањата на клиентот. Во овој почетен чекор, се дефинираат карактеристиките на производот, врз основа на анализа на конкуренцијата и барањата на купувачите.

2. Избирање на технички решенија. Во овој чекор се врши специфицирање на функциите кои ги исполнуваат горенаведените барања, кои подоцна се трансформираат во технички решенија.

3. Генерирање на концепти. Ова е основниот чекор на MFD, каде што се креираат модулите на производот, по анализата на техничките решенија. Анализата е изведена како критериум од дванаесет двигатели на модуларноста (пренос, технолошка еволуција, планирани дизајн промени, спецификации, стил, заедничка единица итн.).

4. Оценка на концептите. Во овој чекор, се одредува односот помеѓу интерфејсот на модулите.

5. Подобрување на секој модул. Последниот чекор на методот вклучува дефинирање на спецификациите на модулите (технички информации, цени итн.). Врз основа на овие спецификации, може да се добие деталниот дизајн и оптимизацијата на секој модул.

MFD, исто така, укажува на идеалниот број на модули во производот, како квадратен корен од бројот на збирот на операции во просечниот производ. Покрај тоа, дизајнот кој се однесува на интерфејсот ги зема во предвид параметрите како бројот на контакт интерфејси, размена на информации помеѓу модулите (проток на материјал, енергија, сигнали итн.). Иако постојат неколку дизајн методи што доведуваат до модуларна архитектура, како што покажале Холта и Салонен [18], секој од нив дава различни резултати со истиот идентичен влез. Ова се случува, поради различните перцепции и полиња на примена на секој метод.

Со цел да се изврши прилагодување на производ за да се добие пониска цена, висок квалитет и во исто време голема количина за на испорака, треба да се исполнат две основни барања. Прво, потребни се технологии способни за вршење на прилагодување, обратно инженерство, напредни CAD техники, информатичка технологија, неконвенционалните методи на производство се некои од овие технологии. 
Во исто време, сложеноста на дизајнот на производот треба да се зачува на минимално ниво. Ова се постигнува со изработка на модуларен дизајн, распоредување на фрункциите и структурирање на интерфејсите. Веќе постојат голем број на модуларни производи кои покриваат широк спектар на индустриски сектори, од софтвер за автомобили и компјутери, играчки, чевли и многу други.

\section{3 Мултифункционалност на производите}

Истражувањето во дизајнот за развој на мултифункционални производи мора да се фокусира на специфични пазарни сегменти, со цел да се задоволат желбите и потребите на потрошувачите, со што треба да се развиваат концепти да ги задоволат тие барања.

Затоа не е доволно да се состави традиционално трендовско истражување и едноставна пазарна и потрошувачка анкета. Во овој приод кон диференцијација на производи е нивната способност за мултифункционалност. Дизајнерското истражување, исто така, мора да се посвети на новите материјали и технологии што можат да придонесат за развој на мултифункционални производи.

Производите, кои и да се, се замислени да се користат, ракуваат и употребуваат од страна на потрошувачите. Во оваа смисла, важно е да се разгледа удобноста, психолошката и естетската „удобност“, како и чувствителноста, термофризиолошката и ергономската удобност.

Од аспект на овие барања кои се од големо значење треба совршено да се разбере она што го прави потрошувачот "да се чувствува добро" и како тој го прави тоа да влијае на неговата психо-естетска „удобност“.[19]

Фактот дека производот е развиен само за специјално одреден пазарен сегмент (како што е лица со одредена стапка на инвалидитет, слепи или постари лица) не гарантира успех. Вистината е дека овие лица имаат тенденција да не им се допаѓаат производите што ги "стигматизираат". Во случај на некои производи, како што е ранецотза планинарење, потребно е развојните концепти да најдат начини да се прилагодат со цел да се направат соодветни за што поголем број корисници, барајќи инклузивен дизајн за производот. Ранецот за планинарење има најмалку две главни функции, особено во современите општества, функција за пренос на опрема и заштитна функција. Главната цел на ранецот за планинарење е да собере што поголема количина на опрема, храна и останати предмети за да може човекот секогаш да ги носи со себе. 
Во последната деценија се забележува значително зголемување на побарувачката за високодиференцирани производи со значителна додадена вредност, кои во исто време треба да се лесни за употреба, удобни, флексибилни за носење и со модерен изглед. Во оваа група на производи се и ранците за планинарење. Со цел да се развијат мултифункционални производи, постои значителен број на клучни елементи кои треба да се земат предвид во процесот на дизајнирање, како што се:

- Текстилните материјали и технологии, особено новите материјали и технологии кои можат да придонесат за развиените производи да се навистина мултифункционални;

- чувство на целосна удобност;

• дизајн истражување

- тестирање и евалуација на концепти

- Пристап за инклузивен дизајн

Вкупната удобност,т.е. "пријатна состојба, фризиолошка, психолошка и фризичка хармонија помеѓу човечко суштество и животната средина "[20], како универзален основен услов за човекот, во областа на дизајнот на ранци игра голема улога. Многу истражувачи испитувале удобност во текот на изминатите години, но до сега, нема јасна дефиниција за неа, бидејќи оваа субјективна перцепција се разликува од личност до личност.

Fourt и Hollies велат дека ффизички удобноста може да биде под големо влијание на тактилни (сензорни удобности) и топлинска сензација (Thermophysiological Comfort), што произлегува од контакт помеѓу кожата и непосредната состојба од животната средина [21], но не можеме да го занемариме психоестестичниот аспект, како и ергономскиот аспект на удобност. 


\section{3. ПРИНЦИПИ СО КОИ СЕ ПОСТИГНУВА ОПТИМИЗАЦИЈА НА ПРОСТОРОТ ИНСПИРИРАНИ ОД ПРИРОДАТА}

Биониката е релативно нова интердисциплинарна наука која се занимава со појави, структури, механизми и фрорми кои се среќаваат во природата, чие препознавање и проучување може да помогне во решавање на дизајнерски и инженерски проблеми. Бионичкиот дизајн е алатка која обезбедува фрункционални принципи и форми од природата како инспирација при генерирање концепти и развој на производи. Тој ги поврзува дизајнот и научните дисциплини од разни области во обезбедување релевантни факти и информации кои се важни аспекти во дизајнот и развојот на производи.

Бионичките методи во процесот на дизајн на производи се применуваат со два вообичаени пристапи:

- пристап каде процесот е воден од бионичко решение до можно решавање на дизајнерски проблеми

- $\quad$ пристап каде процесот е воден од зададен дизајнерски проблем до потрага по решение во биолошките системи

Многу истражувачи работеле на развивање на стратегии и методи за практикување на биолошки инспириран дизајн. Версос и Коељо [22] го предлагаат двонасочниот метод на бионички дизајн кој сугерира низа чекори во процесот на дизајнирање кои би можеле да се практикуваат во било која од двете алтернативни ориентации на процесот на бионички дизајн. Чекорите во двете насоки на анализа се состојат од истите активности, содржат ист опис и се применливи за двете ориентации. Хелмс, Ватам и Гоел [23] предлагаат организациска рамка за практикување на биолошки инспириран дизајн, кој може да се примени во процес воден од зададен проблем, исто како и во процесот управуван од препознаени решенија од природата.

Според Хелмс (2009) [23], со цел да се најдат решенија аналогни на биологијата, дизајнерите мораат да ги редефинираат и реструктурираат проблемите и функциите и да ги прилагодат на соодветни проблеми кои ги има во природата и како тие таму се решаваат. Секогаш се поставува прашањето „како природата го прави или не го прави тоа“. 


\section{1 Потрага по бионички решенија за максимално искористување на просторот}

Стратегијата на дво-насочниот бионички метод на Версос и Коељо [22] е усвоена за понатамошна примена со цел да се проучат бионички примери за да се дојде до сознанија кои можат да дадат одговори на поставените цели - мултифункционалност и оптимизација на просторот. Дво-насочниот бионички метод се состои од следните чекори:

$>$ Дефинирање на проблемот

$>$ Реформулирање на проблемот

$>$ Избор на решенија

$>$ Анализа на решенија

$>$ Генерирање на концепти

$>$ Избор на концепти

$>$ Детална разработка

Најпрво е потребно да се идентификуваат и разложат структурите, компонентите, процесите и функции на биолошкото решение, поврзано со проблемот. Разбирањето на различните аспекти на биолошките карактеристики на решението може да помогне да се задоволат повеќе барања, вклучувајќи ги и ефективноста, структурните, функционалните и организациските нивоа.

Функционалната декомпозиција извршена во чекорот на дефинирање на проблемот може да биде корисна со цел да се поврзе секоја функција или под-функција и барање на проблемот со функции и карактеристики на биолошкото решение. Решението кое е најрелевантно и изводливо за посебните предизвици на проектот може да се идентификува и извлече во фрорма на алтернатива, која бара максимално намалување на структурните и еколошките услови и ограничувања на природата.

По екстракција на принципите на биолошкото решение и според изводливоста за имплементација и потребите на поставениот дизајнерски проблем, дизајнерите можат да развијат идеи и концепти врз основа на природни модели, следејќ ги упатствата и принципите добиени во чекорите за анализа на биолошкото решение и дефинирањето на проблемот. 


\subsection{1. Дефинирање на проблемот}

Според усвоената стратегија на дво-насочниот бионички метод на Версос и Коељо [22] процесот започнува со дефинирање на проблемот. Во овој случај, поточно во конкретниот магистерски труд, се работи за препознавање принципи инспирирани од природата со кои се постигнува оптимизација на просторот, со други зборови „како да се обезбеди максимално искористување на просторот“.

\subsection{2 Реформулирање на проблемот}

Следниот чекор е редефинирање и реструктурирање на проблемите заради прилагодување на соодветни проблеми кои ги има во природата. Тие треба да бидат одговор на прашањето „како природата го прави или не го прави тоа“.

Во левата колона на табелата 3.1 се сместуваат сите можни изрази со кои може да се опише дефинираниот дизајнерски проблем. Во десната колона се сместени соодветните реформулирани изрази кои одговараат на прашањето „Како природата го прави тоа“.

\begin{tabular}{|c|l|}
\hline $\begin{array}{c}\text { Декомпозиција на дизајнерскиот } \\
\text { проблем }\end{array}$ & \multicolumn{1}{|c|}{ Како природата го прави тоа } \\
\hline $\begin{array}{l}\text { трансформација на фрормата } \\
\text { нромена на форма, промена }\end{array}$ & $\begin{array}{l}\text { Како природата обезбедува трансформација на } \\
\text { формата на телото кај живите суштества }\end{array}$ \\
\hline $\begin{array}{l}\text { модуларен распоред на } \\
\text { сегменти }\end{array}$ & $\begin{array}{l}\text { Како природата обезбедува најефикасно } \\
\text { распоредување на сегментите кај живите } \\
\text { суштества }\end{array}$ \\
\hline компактна фрорма & $\begin{array}{l}\text { Како природата обезбедува компактност на } \\
\text { формата на телото кај живите суштества }\end{array}$ \\
\hline мултифунционалност & $\begin{array}{l}\text { Како природата обезбедува мултифунционалност } \\
\text { кај живите суштества }\end{array}$ \\
\hline
\end{tabular}

Табела 3.1 : Реформулирање на проблемот 


\subsection{3 Пребарување на реформулираните принципи низ богатата ризница на природните системи}

По реформулирањето на барањата, функциите и карактеристиките присутни во Природата, преку преглед на литература и теренски набљудувања, откриени се биолошки решенија кои најдобро ги решаваат дефинираните проблеми.

\subsubsection{1 Модуларен распоред на сегменти}

Најголемиот број од живите суштества имаат сложена градба. Многу од нив имаат градба во вид на структури составени од сегменти. Начинот на нивното разместување најчесто е правилен во вид на матрици или спирали.

Спирални структури се забележани кај многу растенија. На пример, шестоаголните сегменти од плодот на ананас (слика 3 и слика 4) се само еден пример во семејството на растенија во кои се забележани спирални структури. Бројот на спирали е во склад со броевите на низата на Фибоначи. Цветовите на сончогледот обично имаат 55, 89 или 144 ливчиња, а спиралните обрасци се евидентни во распоредот на нивните семиња(Слика 3.1 и слика 3.2).

Семето на сончогледот е наредено на начин кој ефикасно го користи расположливиот простор, давајќи максимален простор за секое семе да процвета и минимизирање на трошењето на просторот. Како што никнува новото семе на врвот на растението, природно има тенденција да расте таму каде што има најмногу отворен простор. Секое семе се поместува во однос на претходното со златниот агол.

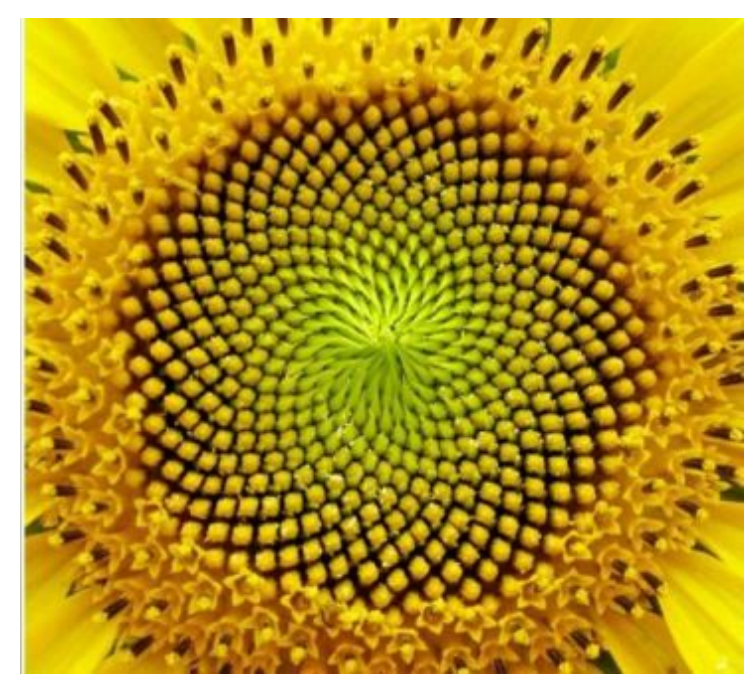

Слика 3.1 Семе од сончоглед

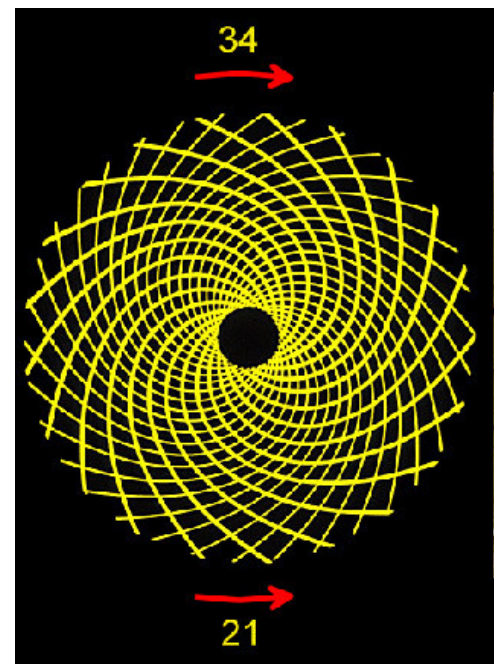

Слика 3.2 Распоред на семето од сончоглед 


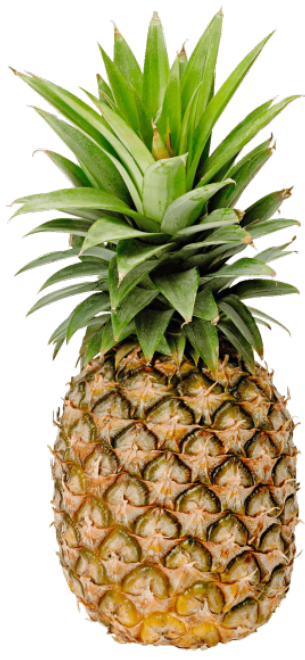

Слика 3.3 Ананас

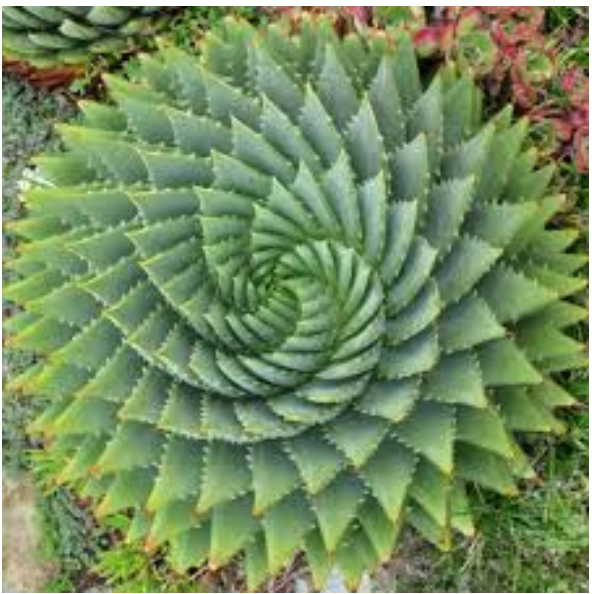

Слика 3.5 Спирална структура на Алое

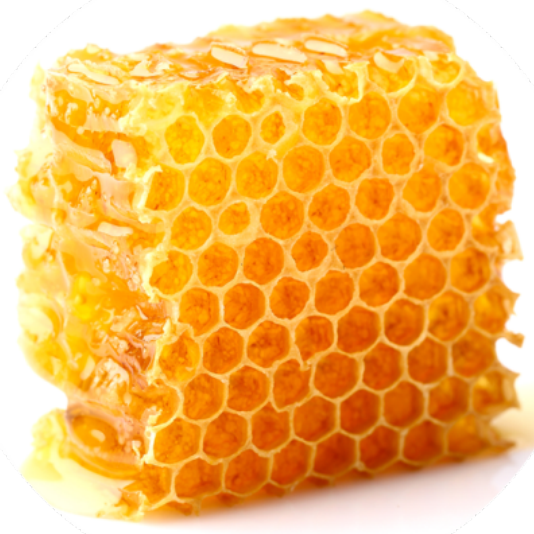

Слика 3.7 Восочна структура од пчелно легло

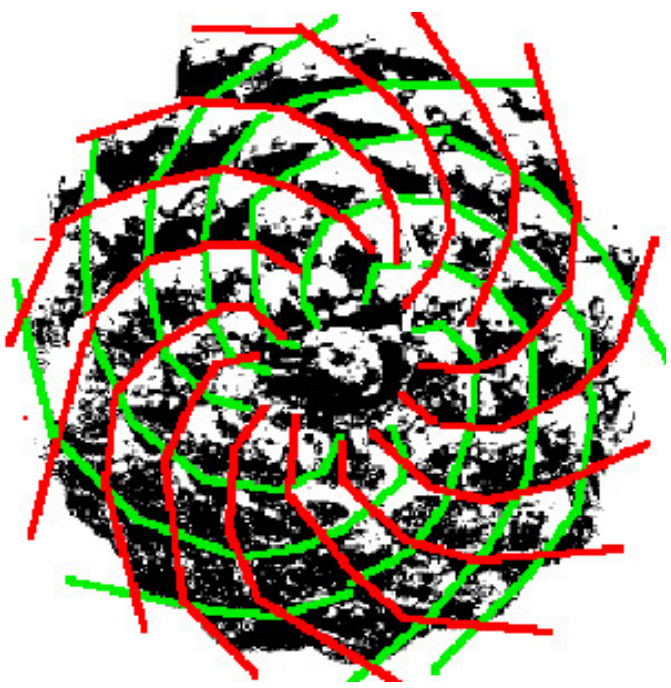

Слика 3.4 Спирална структура на ананас

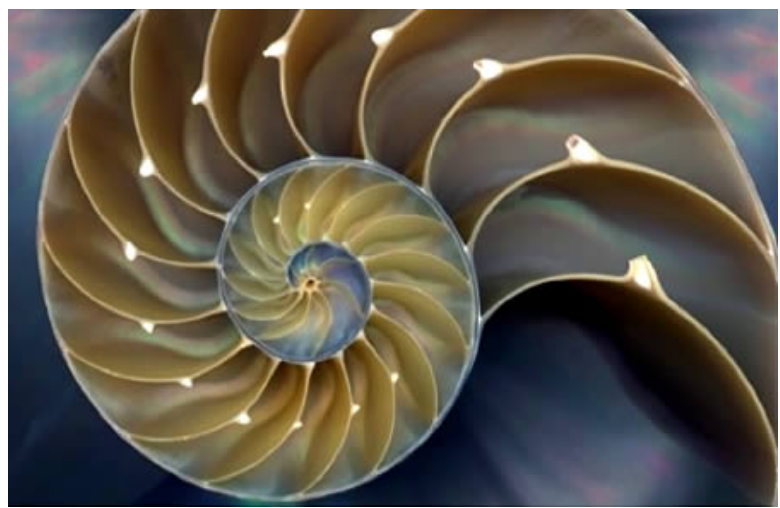

Слика 3.6 Спирална структура на полжав

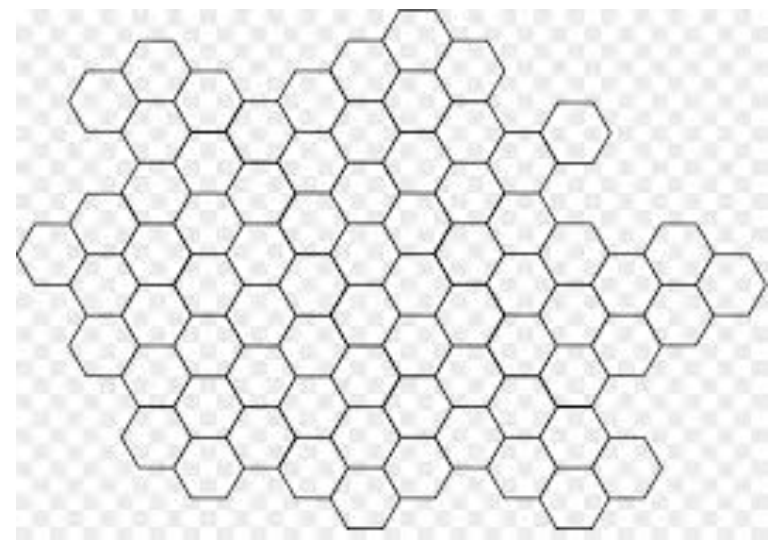

Слика 3.8 Хексагонален распоред на восочна структура 


\subsubsection{2 Трансформација на формата}

Трансформација на формата е многу битна способност која ја поседуваат многу суштества и им служи за одбрана. Најчесто се случува со промена на формата во вид на сорера. Таков е примерот со армадилото и панголинот (Слика 3.9, Слика 3.10, Слика 3.11 и Слика 3.12). Сите ранливи и витални органи како и екстремитетите се свиткуваат далеку во внатрешноста на заштитната обвивка.

Природата обезбедила различни принципи на трансформација на фрормата на живите суштества. Иако примарна цел на овие трансформации е заштита од предатори, фактот дека целото тело се трансфоррмирало во помал волумен, најчесто во облик на топка, значи дека просторот во топката е максимално искористен за сместување на телото.

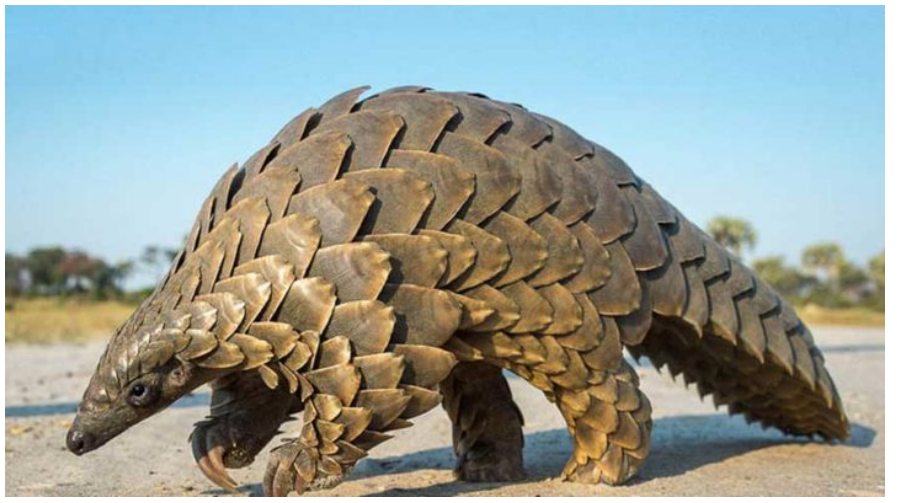

Слика 3.9 Панголин

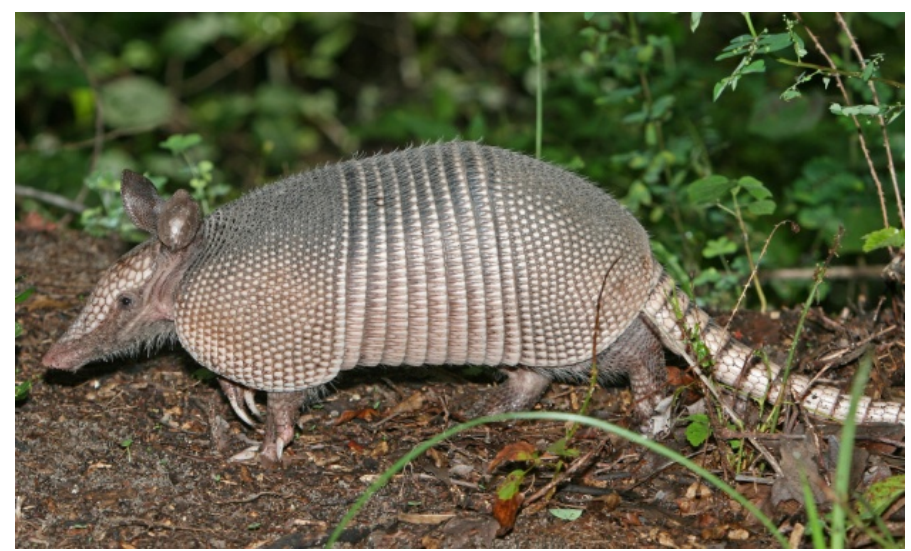

Слика 3.11 Армадило

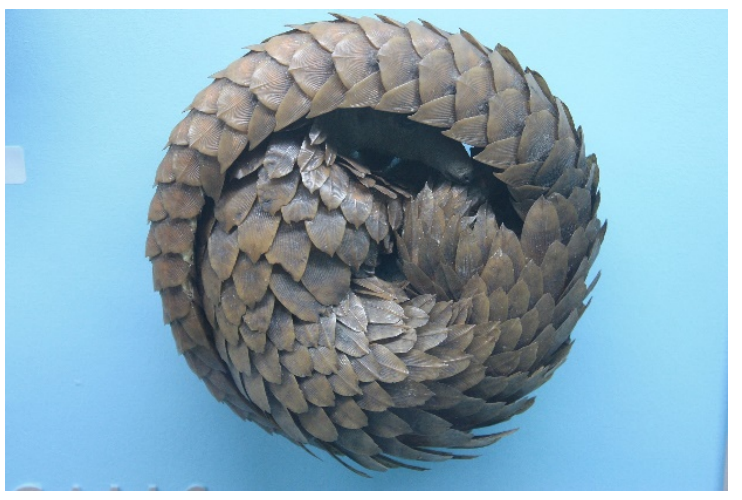

Слика 3.10 Панголин во одбранбена положба

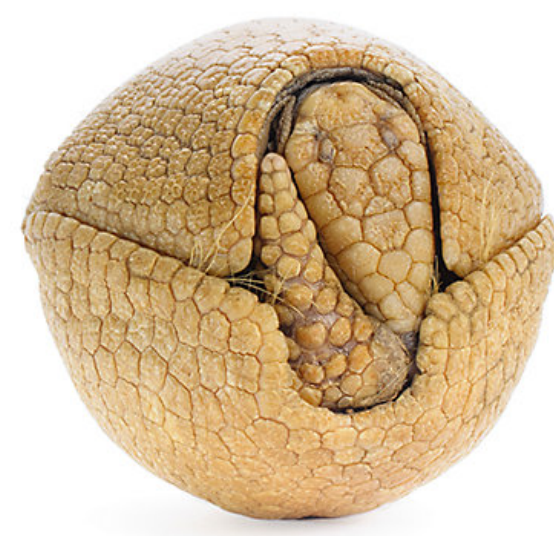

Слика 3.12 Армадило во одбранбена положба 


\subsubsection{3 Мултифункционалност}

Во природата се среќаваат голем број примери на мултифунционалност. Таков е примерот со некои видови инсекти (лебарки, бумбари, скакулци и др.) чија надворешен оклоп е единствениот скелет на кој се прицврстени другите органи (сл.3.13), кој истовремено е и единствената заштита од надворешни влијанија. Сличен е случајот и кај некои морски безрбетни суштества, како што е ракот (сл.3.14). Мултифунционалноста обезбедува заштеда на ресурси, материјали и простор.

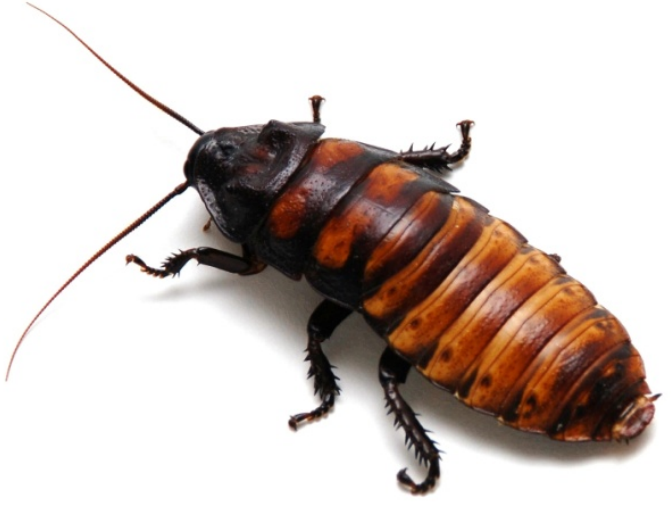

Слика 3.13 Лебарка

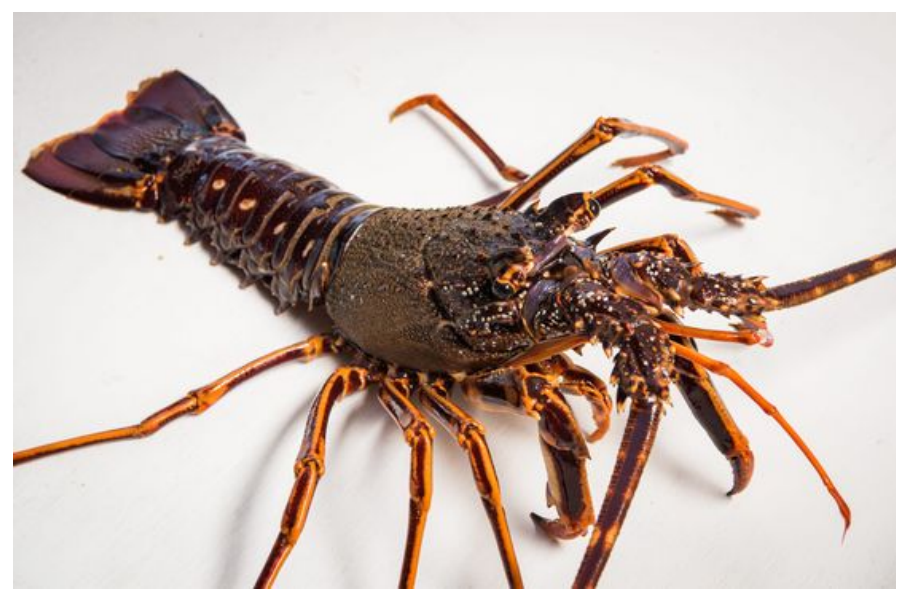

Слика 3.14 Морски рак

\section{2 Заклучоци од извршените бионички истражувања и поставување на}

\section{хипотези}

Врз основа на извршените бионички истражувања поставени се неколку претпоставки, хипотези, кои се однесуваат на оптимизација на простор и обезбедување мултифункционалност во дизајнот на производи:

- Геометриски форми базирани на правилни многуаголници обезбедуваат подобра оптимизација на просторот отколку органските форми.

- Примената на модуларниот пристап обезбедува подобра оптимизација на просторот.

- Структури од модули подредени ортогонално обезбедуваат максимално искористување на просторот.

- Структури од модули подредени со примена на принципот на златен агол формираат спирали и обезбедуваат максимално искористување на просторот.

- Еден производ со повеќе функции ќе обезбеди поголем корисен простор и намалување на димензиите на производот. 


\section{4. ДЕФИНИРАЊЕ НА ДИЗАЈНЕРСКИ ПРОБЛЕМ - МУЛТИФУНКЦИОНАЛЕН РАНЕЦ ЗА ПЛАНИНАРЕЊЕ}

Со цел да се потврдат и докажат поставените хипотези беше избран конкретен дизајнерски проблем - компактен ранец за пакување и пренос на опрема за планинарење.

Акцентот ќе се стави секако на удобноста и можноста за прилагодување кон секаква возраст и фризички карактеристики на корисниците. Покрај удобноста ќе се разработи и идејата за вградување на самата опрема во ранецот која ќе зафаќа помалку волумен, а со мала трансформација ќе ги исполни нејзините задачи.

Планинарењето како спорт во денешно време се смета за најздрава фризичка дисциплина. Терминот планинарство е поширок поим за бројни активности како: излети, совладување на лесно пристапни терени, високогорство, спелеологија, спасувачки служби, скијање и алпинизам. Сите овие погоре споменати активности се изведуваат во разни временски услови, непредвидливи моменти, различни терени, далеку од цивилизацијата, во еден друг свет. Во зависност од релациите и временскиот интервал за престој потребна е соодветна опрема која треба да ја има секој планинар со себе, неопходна за носење со себе, а под услов екстремитетите да останат слободни. Сето ова придонело за развој на производ кој бил наречен ранец (backpack) или во превод значи нешто што се носи на рамена.

Главно барање кај овој тип на производ е пренос на што поголема количина неопходни предмети за преживување во планински услови за период од најмалку 48ч заради обезбедување поголеми удобности за корисникот - планинар (хигиена, исхрана, одмор, заштита, конекција). Почетните барања за производот беа фокусирани на:

- отпорност на секакви временски услови,

- прилагодливост за различна категорија на корисници,

- поголем капацитет за сместување на опрема,

- адаптибилност,

- ергономска градба,

- добро организиран и прегледен,

- едноставен за употреба,

- лесен 


\section{1 Постоечки производи за носење планинарска опрема - РАНЦИ}

Ранците служат за мобилност на што поголема количина опрема со себе. Постојат многу видови на ранци за секакви потреби: училишни, модни, тактички, планинарски, деловни. Од сите овие најголеми се планинарските, затоа што е потребно да се смести многу опрема со една цел - да може човекот лесно да се движи и да биде слободен. Основна опрема која треба да се смести во еден планинарски ранец е: резервна облека, храна, течности, шатор, вреќа за спиење, планинарски алатки, помошни алати, прибор за јадење, електронски уреди и слично. Сето ова на едно место зафаќа голем волумен и создава голема тежина која паѓа на товар на р'бетот. Поради овие причини најважни при дизајнирање на ранец за планинарење се ергономијата и изборот на материјали за изработка.

Ранци најчесто користат туристите и учениците, а често се претпочитаат за носење тешки товари или носење каква било опрема, поради ограничениот капацитет за носење предмети подолго време во рацете.

Големи ранци, кои се користат да носат товар поголем од 10 килограми, како и помали спортски ранци (на пример, за трчање, возење велосипед, пешачење), обично оптоваруваат околу $90 \%$ од колковите. Примена на потпора за колковите го подобрува потенцијалот за носење тешки товари, бидејќи колковите се посилни од рамената, а исто така ја зголемува агилноста и рамнотежата, бидејќи товарот се носи поблиску до сопственото тежиште на масата на човекот.

Постојат 4 категории на ранци: без рамка, надворешна рамка, внатрешна рамка и телесни.

Кај ранците кои имаат рамка, таа служи за поддршка и соодветна дистрибуција на тежината на неговата содржина преку телото, пренесувајќи поголем дел од тежината на колковите и нозете. Затоа, поголемиот дел од тежината се отстранува од рамената, намалувајќи ги шансите за повреда од притисокот на прерамката на рамото. Повеќето ранци можат да бидат затворени со механизам, со патент и со класична трака.Телесен ранец е опремен со еден или повеќе џебови кои се поврзани на градите на носителот и се натоварени на таков начин што товарот во предниот дел и оптоварувањето во грбот се блиску до еднакви. Поголемиот дел од оптоварувањето го носат колковите. Идеалниот систем за носење на товарот не треба да го наруши природното држење на телото, балансот и маневрирањето. Товарот мора подеднакво да се расфрла на скелетната конструкција, и не треба да произведува неурамнотежени сили на телото. 
Наједноставниот дизајн на ранец е торба прикачена со ремени на рамо (слика 4.1). Tие се користат за општ транспорт на стоки и имаат променлив капацитет. Наједноставните дизајни се состојат од еден главен џеб. Пософистицираните модели имаат дополнителни џебови, ремени за градите, обложени ремени, подлошки, а понекогаш и рефлективни материјали за дополнителна безбедност во текот на ноќта. Овие ранци генерално се поефтини за изработка.

Тоа се дневни ранци со мал капацитет од десет до триесет литри. Ранците за треккинг и планинарење обично се најголеми и најтешки, честопати со капацитет триесет и пет до шеесет и пет литри.

\section{* РАНЦИ СО НАДВОРЕРШНА РАМКА}

Ранците со надворешни рамки (слика 4.2) се дизајнирани да носат тешки товари (> 20 кг ), давајќи им на корисниците повеќе поддршка и заштита и подобра дистрибуција на тежината од едноставна торба без рамка. Ранци со дрвени рамки се користеле со векови низ целиот свет. Таквите ранци се вообичаени за воени и планинарски цели, металните верзии првпат се појавиле во средината на 20 век.

Надворешната рамка обично е изработена од алуминиум или друга лесна метална легура, а од неодамна се применуваат засилени синтетички полимери или пластика.

Таа е опремена со систем на ремени и издолжена мрежа која спречува контакт помеѓу металната рамка и корисникот. Во прилог на удобноста, оваа мрежа обезбедува дополнителна корист -циркулација на воздухот помеѓу рамката и грбот на носителот. Поради оваа причина, ранците со надворешни рамки генерално се сметаат за "поладна верзија" отколку внатрешните конструкции на рамки. Ранците со надворешни рамки имаат дел од ткаенина, кој обично е помал од оној на внатрешните рамки, но има изложени делови над и под вреќата за да обезбедат приврзување на поголеми предмети. Покрај тоа, ткаенината често може да се отстрани целосно, дозволувајќи му на корисникот да ја прилагоди конфигурацијата на нивниот товар, или да пренесе неконвенционален товар, како што е уловен дивеч. Воените ранци често се дизајнирани како надворешни рамки поради нивната способност да носат товар од различни форми, големини и тежини.

Друг тип на надворешна рамка која неодамна беше предложена е изработена од композитна пластика, која не е флексибилна, а исто така е еден вид материјал кој може да се обликува како кривина според човечкиот 'рбет. Во овој тип на ранец, оптоварувањето директно се пренесува на рамениците преку не-флексибилни ремени. 
Оваа не-фрлексибилна структура го намалува притисокот на лумбалниот дел од грбот. Заоблувањето на ременот е обликувано во близина на кривината на 'рбетот и има две флексибилни прицврстувачи за да се спречи движењето на ранецот во попречна рамнина. Ремените од овој ранец се доволно широки за да го дистрибуираат притисокот врз рамената, а во внатрешниот дел од нив се додава и слој од бела стаклена волна за да се апсорбираат динамичните сили, кои може да се создадат преку одење. Овој вид на ранец е експериментален примерок за кој се потребни дополнителни опции за да се подготви за употреба. Една од придобивките на ранецот со надворешна рамка е спречување на 'рбетот да се придвижи нанапред за време на одењето.

\section{* РАНЕЦ СО ВНАТРЕШНИ РАМКИ}

Ранецот со внатрешна рамка (слика 4.3) е неодамнешна иновација. Пакетот за внатрешна рамка има голем дел од ткаенина околу внатрешната рамка составена од ленти од алуминиум, титан или пластика, понекогаш со дополнителни метални остатоци за зајакнување на рамката. Сложена серија на ремени работи во комбинација со рамката за да се дистрибуира тежината и да се одржи во место.

Внатрешната рамка овозможува пакетот тесно да се вклопи во грбот на корисникот и да го минимизира пренасочувањето на товарот, што е пожелно кога учествува во активности кои вклучуваат движење на горниот дел од телото, како што се одење преку карпести површини и скијање. Сепак, цврстото затворање ја намалува вентилацијата, па така овие пакети имаат тенденција да бидат повеќе испотени отколку кајранците со надворешни рамки. Внатрешната конструкција, исто така, овозможува голем простор за складирање. Бидејќи рамката е целосно интегрирана, тешко е да се прицврстат поголеми и потешки предмети кои не се вклопуваат во внатрешноста на одделот однадвор од пакетот. Пакетите за внатрешна рамка имаат помал капацитет и помалку удобно се прилагодуваат на грбот на корисникот за време на постојано одење, но поновите модели се подобриле во голема мера во овој поглед.

\section{* РАНЦИ ЗА СЕКОЈДНЕВНО КОРИСТЕЊЕ}

Еднодневните ранци се помали, без рамка, може да собере доволно опрема неопходна за еден ден. Тие не се доволно големи за да соберат вреќи за спиење и спакувани шатори.

Во многу земји, ранците се силно идентификувани со учениците и се основно средство за транспорт на едукативни материјали до и од училиште (слика 4.4). Во овој контекст тие понекогаш се познати како ташни. Купувањето на соодветно модерен, атрактивен и корисен ранец е клучен за учениците кои пешачат до училиште. 
Вообичаено училишните ранци немаат цврста рамка од надворешна страна и имаат само неколку џебови во предниот дел, покрај главниот простор за складирање.

Додека традиционално се многу едноставни во дизајнот, училишните ранци често се направени со дополнително зајакнување за да се сместат голем број на тешки учебници, како и безбедносни карактеристики како што се рефлексивни панели за да ги направат носителите на ранецот забележливи ноќе.

Ранци понекогаш се носат како модни додатоци, при што ја извршуваат истата функција како чанта. Некои такви ранци, дизајнирани специјално за жени, не се поголеми од една типична чанта и обично им одговарат на помлади жени.

\section{* РАНЦИ ЗА ПРОФЕСИОНАЛНА УПОТРЕБА}

Ранци се стандарден дел од опремата за носење на војници, особено пешадија, во повеќето земји, а ранците во воен стил редовно се достапни за цивили во воените продавници (слика 4.6). Таквите ранци честопати, но не секогаш се ранци со надворешни рамки. Просторот за скалдирање, пакет, е прицврстен или закачен на метална или пластична носечка рамка. За единици кои влегуваат во борбени ситуации, ранците може да тежат повеќе од 45кг.. Секој војник може да носи дополнително оружје, муниција, оброци, медицински материјали, шатори или друг материјал и дополнителна облека.

Неодамна, еден бренд за производство на ранцилансира на пазарот специјално дизајниран ранец за професионални готвачи и кулинарски студенти. Овој вид ранец е наменет за безбедно носење ножеви, алатки за готвење и друга разновидна опрема, како што се тетратки, крпи и униформи.

Специјалните ранци се користат од страна на противпожарни служби за борба против шумски пожари, како и од спасувачките служби за пребарување и спасување.

Овие ранци обично се модуларни, овозможувајќи му на пакетот да се реконфигурира според желбите на корисниците и да биде дизајниран да ги оптоварува колковите за носење.

\section{* РАНЦИ ЗА СПЕЦИЈАЛНИ НАМЕНИ}

Некои ранци се специјално дизајнирани да носат одредени предмети. Вообичаените примери вклучуваат ранци за мали вредни предмети, како што се лаптопи и камери; ранци дизајнирани за одржување на лап-топ компјутери (слика 4.7).

Тие вообичаено имаат преграда за држење на компјутерот и средните џебови и капаци за да се сместат додатоци, како што се кабли за полнење и периферни уреди . 
Со цел да ги снабдуваат овие уреди со електрична енергија, постојат ранци опремени со соларни панели.

Ролинг ранци се ранци со тркала на дното и рачка која се истегнува. Поради нивниот дизајн, тркалачките ранци го намалуваат притисокот врз корисникот, иако рачните ремени може да се користат за носење на ранецот за кратки растојанија кога теренот не е погоден за тркала.

\section{* ПЛАНИНАРСКИ РАНЦИ}

Планинарските ранци се изработуваат од полиамид и полиестер (слика 4.8 и слика 4.9). Ги има во различни големини и форми, а воглавно се делат на едноставни, дводневни и транспортни т.е. движечки ( трекинг, хајкинг) и алпинистички. Тие главно се разликуваат според положбата на појасите. Транспортните ранци поголемиот дел од тежината ја пренесуваат на колковите.

Ранецот не смее да биде многу поширок од грбот (треба да се избегнуваат странични џепови) за да нема проблеми кога се поминува низ тесни пролази.

Нарамениците на ранецот во кој се планира да се носи поголема тежина треба да бидат широки и поставени со мек материјал. Најважен елемент на ефикасна употреба на ваков ранец е начинот на сложување на опремата што се носи во ранецот.

Најпрво треба да се посвети внимание на потребите при престојот во планина. Опремата која може да му биде потребна на корисникот треба да биде достапна. Комплетот за прва помош, капа, ракавици, компас, карта и слично треба да се пакува на начин да може многу едноставно и брзо да се дојде до нив додека остатокот од опремата треба да биде спакуван на препорачан ергономски начин. Капата, горниот дел на ранецот, не смее да биде претешка и пренатрупана особено кај полу празен ранец бидејќи може да го занесува ранецот, а со тоа и телото.

Сложувањето на опремата во ранецот, освен во некои посебни ситуации не е препорачливо. Движењето низ природа може да не доведе во разни ситуации и секој вишок на опрема кој не е уредно поставен во ранецот претставува потенцијален проблем (може да отпадне, да се оштети, да се скрши, да се заплетка во гранка, да ја ограничи мобилноста или дури да доведе и до повреди). Ако е ограничен просторот тогаш треба да се следат некои правила: опремата треба да се сложува „во висина“.

Стаповите за одење треба да се спакуваат на начин да врвот секогаш биде свртен према „долу“, а целата опрема која има остри врвови мора да биде изолирана. 
Кај движењето важно е со помош на затегнувачи и појаси на ранецот да се распореди тежината на колковите, а ранецот секогаш да се одржува исправен. Гравитацискиот центар на ранецот секогаш мора да биде што поблиску до средината на лопатките на грбот.

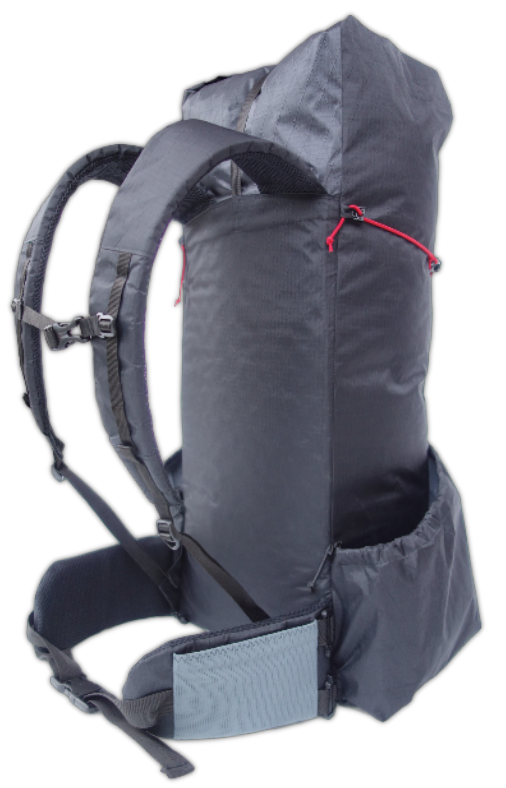

Слика 4.1 Ранец без рамка

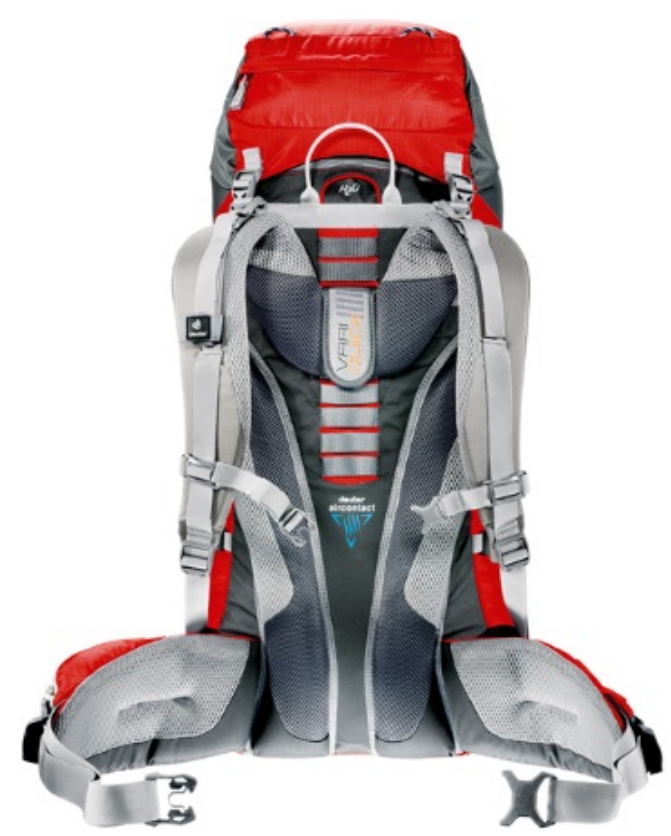

Слика 4.3 Ранец со внатрешна рамка

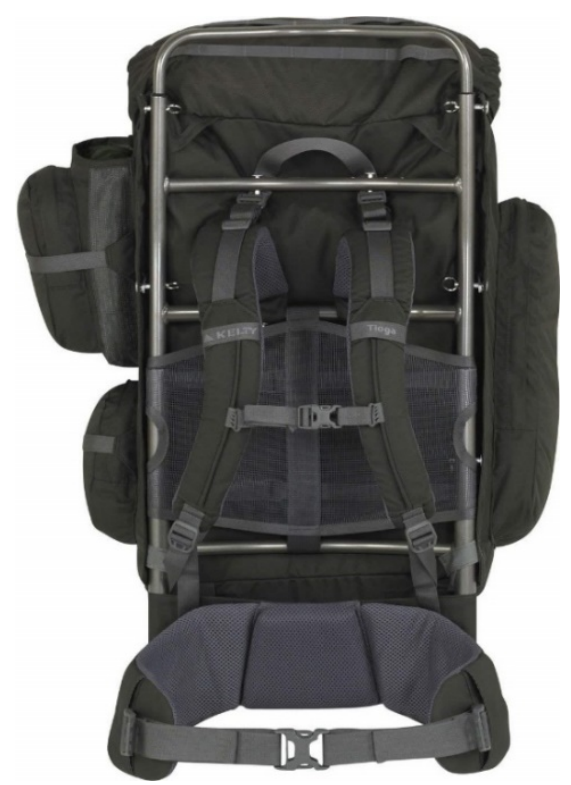

Слика 4.2 Ранец со надворешна рамка

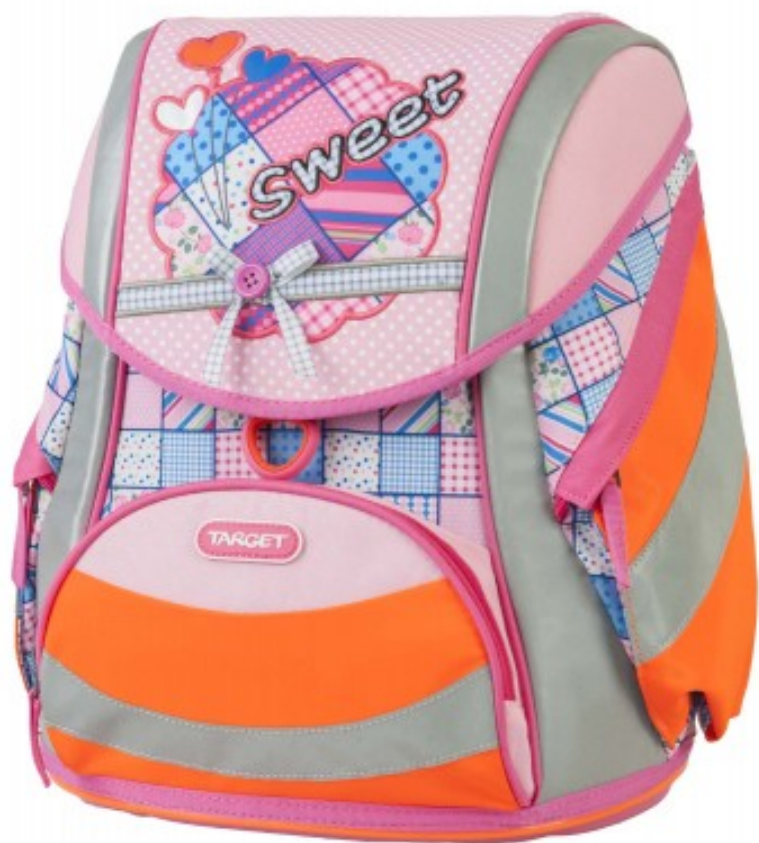

Слика 4.4 Ранец за секојдневна употреба (Школски ранец) 


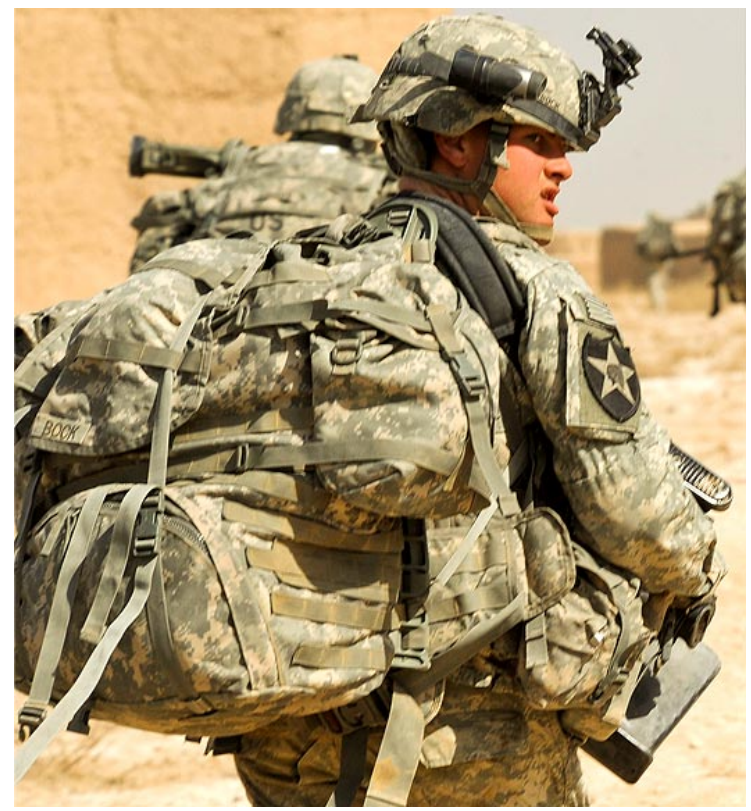

Слика 4.6 Ранец за професионална употреба (Војнички ранец)

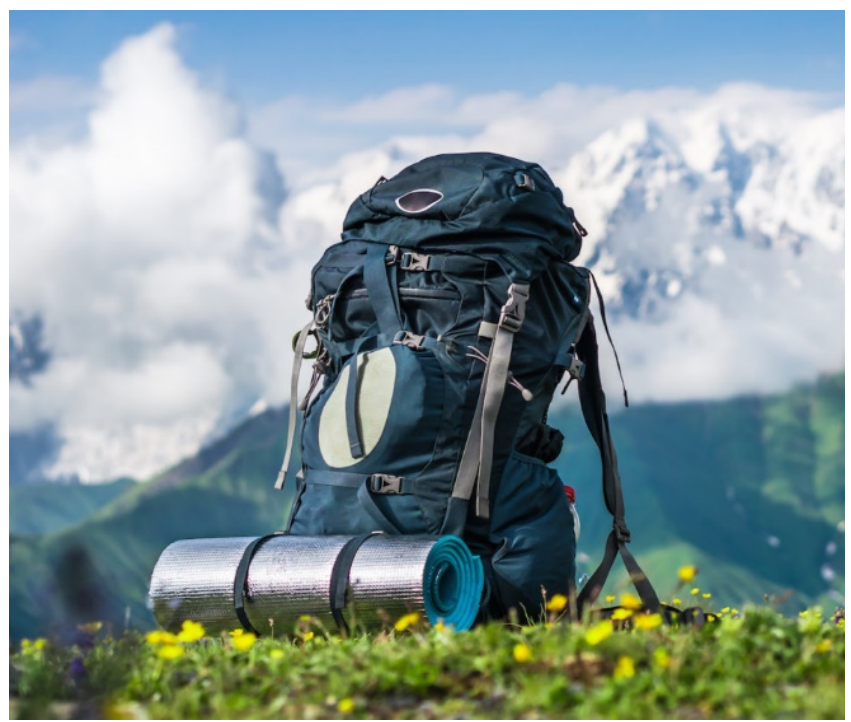

Слика 4.8 Планинарски ранец

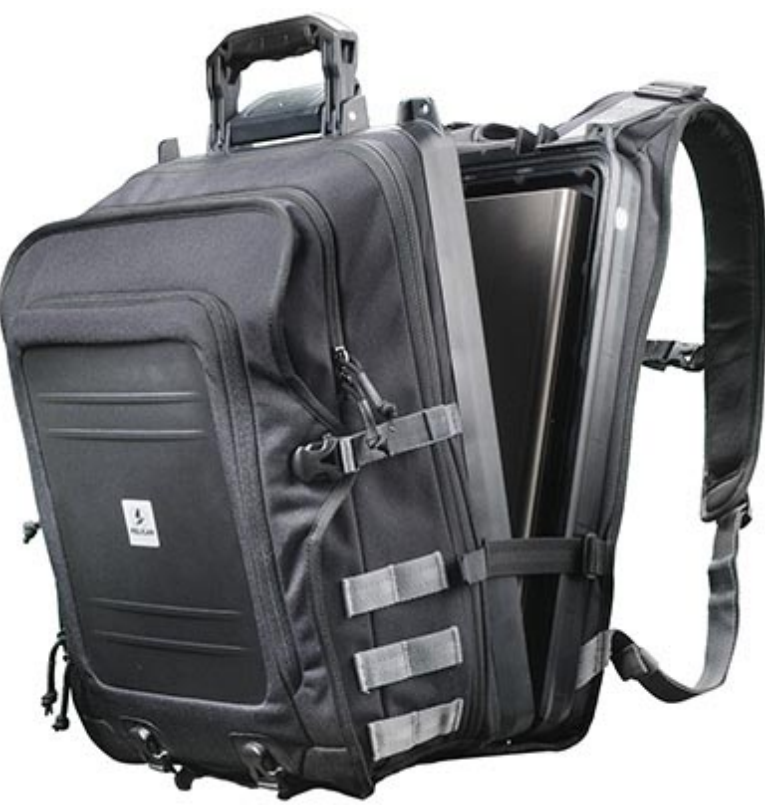

Слика 4.7 Ранец за специјална намена (Ранец на лаптоп)

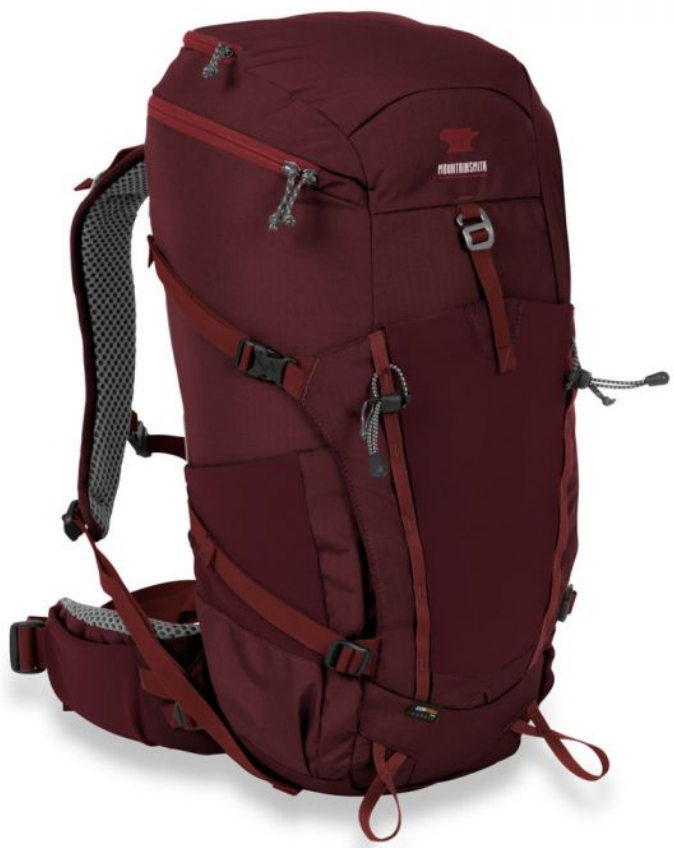

Слика 4.9 Планинарски ранец 


\section{5. ЕРГОНОМИЈА НА НОСЕЊЕ РАНЦИ}

Во процесот на дизајн на ранец ергономијата е многу неопходна, првенствено поради тоа што се работи за производ кој директно се користи врз телото на човекот и мора да биде најдобро прилагоден. При дизајнирање на ранецот ергономијата[24] е тесно поврзана со антропометријата на човекот.

\section{1 Ергономски научни истражувања поврзани со носење ранци}

Постојат голем број на истражувања за ергономијата на ранците, повеќето од нив се ранци за деца на училиште [25] - [28]. Многу истражувачи ги проучувале опширно за фризиолошките, биомеханички и психолошки ефекти на различни видови ранци [29] - [32]. Некои претходни истражувања, исто така, прават споредба на некои различни видови на ранци [33] и [34]. Сепак, сѐ уште постои недостаток од студија во оценувањето планинарски ранци во однос на ергономијата и споредба на некои типови од овие ранци.

Една студија на Ретнари и сор. [35] е спроведена за анализа на употребата на планинарски ранец од страна на планинари. Предмет на истражувањето биле три вида планинарски ранци кои најчесто се користат во Паданг, Западен Суматера Индонезија во однос на ергономијата. Дваесет љубители на природата од Универзитетот во Андалас, Паданг, Западен Суматера, Индонезија (10 машки и 10 женски) учествувале во студијата. Субјектите биле здрави и немале акутни жалби за грбот или вратот што негативно би влијаеле врз нивните перформанси. Нивните просечни карактеристики биле: возраст $21,60(1,82)$ години, раст 1,64 $(0,08)$ м, телесна тежина 55,65 $(9,39)$ кг.

Оваа студијае спроведена со цел да се анализира влијанието на употребата на ранецот врз мускулите на телото и тензијата на срцевите мускули на корисникот. Испитувањето е извршено на три типа на планинарски ранци кои често се користат: Ранец X, Y и Z.

Во оваа студија се користени современи постапки: површинска електромиографија (ЕМГ) за анализа на мускулната активност, електрокардиографија (ЕКГ) за анализа на електричната активност на срцевиот мускул и Nordic Body Map парашалник (NBM) за испитување на корисничките перцепции на мускулно-скелетната непријатност. Во студијата се вклучени дваесет љубители на природата.

ЕМГ и ЕКГ податоците за пребарување, како и пополнување на прашалникот на NBM, се направени пред и по симулирано патување од еден час во лабораторија со користење на лента за трчање на 20 испитаници. 
Откриено е дека корисниците често чувствуваат болка во некои делови од телото по користење на ранци.Најголем проблем корисниците чувстуваат на десното рамо (90\%), на левото рамо (83,33\%), и на половината (60\%).

Студијата, како заклучок, понудила некои критериуми при изборот на ергономски ранец врз основа на анализа на мускулите и електрични активности на срцето на субјектите. Врз основа на активностите на телото и срцевиот мускулкако субјективна мерна анализа, усвоенисе некои карактеристики за удобни или ергономски ранцикои се користат за љубители на природата и планински активности. Некои од нив се изведени како препоракиво дизајнот на ранци:

а. Ранецот треба да има прилагодување за главата, кога телото се наведнува напред

b. Ранецот треба да има систем за прилагодување на грбот

с. Ранецот треба да има добро поставени нараменици кои одговараат на кривата на рамото

d. Ранецот треба да има градус на градната коска кој служи за рамнотежа помеѓу нараменците.

е. Ранецот треба да има добро поставена лента за половината

f. Ранецот треба да има дизајн со надворешна рамка

g. Ранецот треба да има систем за дишење назад

h. Ранецот треба да има рамка од силен илесен материјал.

і. Ранецот треба да има цврста ткаенина и лесна.

j. Торбата треба да се шие уредно и цврсто за да не продира вода кога се користи

к. Ранецот треба да има големина и форма која одговара на големината на телото на корисниците. Се препорачува да се користат ранци со волумен помал од <60 литри за корисници со екстремно ниско или мали ранци со волумен поголем од > 60 литри за корисници со екстремно високо тело.

Авантуристичките активности, особено качувањето или планинарење, стануваат сѐ попопуларни насекаде во светот, особено за младите љубители на природата. Покрај тоа што треба да се има силно и здраво тело (физички и ментално), планинарите исто така треба да бидат опремени со удобна и сигурносна опрема, една од нив е ранецот. Ова влијае на развојот на дизајн на планинарски ранци. 
Дизајнот на сегашните ранци со високи перформанси е многу софистициран со различни карактеристики, големини и цена. Сепак, резултатите од прелиминарните студии покажуваат дека сѐ уште има многу поплаки од корисниците по употребата на овој тип ранци.

\section{2. Ергономски правила во врска со носење ранци}

Планинарските ранци се наменети за сите полови, нации, возрасти и раси, не се произведуваат во различни големини. Ранецот се дизајнира стандардно да може да се користи кај $70 \%$ од луѓето.

Кај ранецот важни се неколку моменти од аспект на ергономијата и удобноста:

- Избор на соодветна големина

- Начин на пакување и распоредување на товарот

- Дизајн на задниот дел од ранецот

\subsection{1 Избор на соодветна големина на ранец}

При изборот на големина на ранец најважна е намената и типот на патување. Има ранци за еднодневна прошетка, викенд ранец, повеќедневен ранец (мах. 5 ноќевања) или експедиционен ранец. Од овој аспект ранците варираат со нивниот волумен од 30 100литри.

Кога се одредува големина на ранец многу е важно да се почитува:

- Висината на телото

- Тип на тело

- Големина на торзо

- Ширина на рамената

Некои производители [36] произведуваат ранци за планинарење кај кои може да се прават подесувања на: висината и должината на нарамениците, ширина на нарамениците, подесувања на појасот и стегачот за градите со цел да одговараат на секаков тип на тело.

На слика 5.1 се прикажани инструкции за избор на соодветен ранец. Подесувањето на нарамениците UP\&DOWN system (слика 5.2) е клучно при избор на соодветен ранец поради тоа што горниот дел на ранецот мора секогаш да биде на рамената, а појасникот треба да има можност за подесување како би ја рапоредил тежината на ранецот точно на нискиот дел од р'бетот кај клучната коска. 


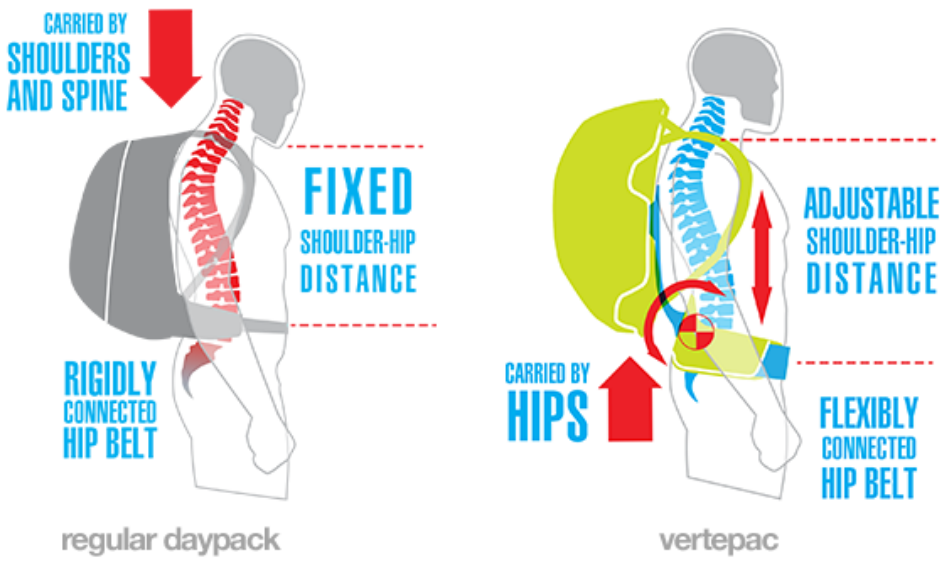

Слика 5.1 Инструкции за избор на соодветен ранец

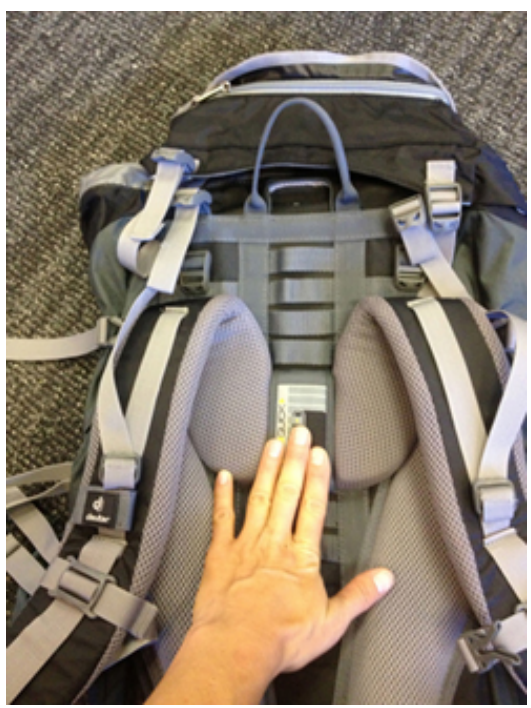

Слика 5.2 UP\&DOWN систем на ергономски грб

\subsection{2 Начин на пакување и распоредување на товарот}

Правилно пакување на ранецот многу придонесува за полесно, безболно, удобно и подолго континуирано користење на истиот. Најважен чекор при пакувањето е да се остават сите излишни работи дома [37] .

Општо правило е дека лице не смее да носи тежина поголема од 20-25\% од својата телесна тежина.

Центарот на гравитација на ранецот треба да биде блиску до телото (слика 5.3), а идеално е во висина на рамената. На овој начин се поставува над тежиштето на телото и ранецот нема да го влече телото према назад.

Постојат многу упатства за правилно пакување на ранец, но ова се некои основни правила:

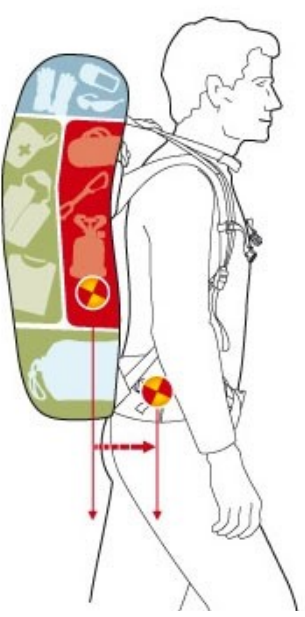

Слика 5.3 Правилно пакување на ранец

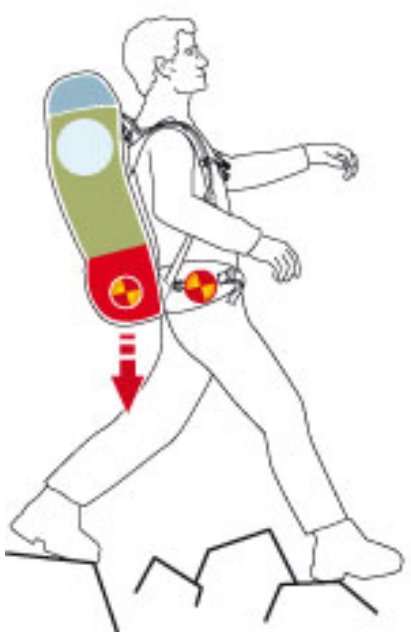

Слика 5.4 Неправилно пакување на ранец 
- Лесни предмети, вреќа за спиење секогаш се ставаат најдолу во ранецот

- Средно тешки предмети и облека се ставаат према врвот кон надворешноста на ранецот

- Тешка опрема како шатор, храна, јакни се ставаат над висината на рамената блиску до грбот

- Мали и најчесто користени предмети се ставаат во џебот на капакот или во страничните џепови каде што може лесно да се дофатат.

Спротивно на тоа, доколку тешките предмети ги ставиме на дното од ранецот, а лесните на врвот (слика 5.4) ќе се случи тоа да центарот за гравитација би се наоѓал на дното од ранецот блиску до клучната коска и целиот товар ќе оди во правец надолу со што ќе се оптеретат директно рамената.

Ранецот различно се пакува за различни терени: на рамни терени точката на гравитација се поставува високо кај рамената, а за тешки и нерамни терени се поставува во средината.

\subsection{3 Дизајн на заден дел на ранец}

Задниот дел е најважниот дел од ранецот бидејќи доаѓа во контакт со грбот и рамената и целата негова тежина постојано се потпира на човековото тело. На овој дел од телото постојано се случува триење, а со тоа доаѓа до топлина и потење на телото. Поради ова најважен е дизајнот и материјалот од кои се изработува задниот дел на ранецот за да се распореди правилно паѓање на тежината на деловите од телото и циркулација на воздух за ладење.

Нарамениците се составен дел од задниот дел на ранецот, тие ја пренесуваат целата тежина на ранецот врз рамената [38] . Материјалите од кои се изработува задниот дел на ранецот треба да ги имаат следните карактеристики: способност за апсорбирање на удар, удобност, да бидат лесни, квалитетни и да дишат [39] .

Најчесто користени материјали од кои се изработуваат нарамениците се:

- $\mathrm{PE}$ (полиетилен) пена со затворена структура која е одличен апсорбер на удари и е многу лесна,

- $\mathrm{PU}$ пената (сунѓер) дава удобност, ЗД мрежа со која се обложуваат пените, која има дополнителна мека структура и овозможува дишење и ладење. 
Иновација во дизајнот на задниот дел на ранецот [40] е креирање на платформа посебен заден дел за ранец, на која може да се прикачуваат повеќе видови на ранци. Ја нарекуваат и паралелен р'бет, ергономскидизајнирана, ја имитира механиката на телото за да се постигнат врвни перформанси.

Оваа технологија го намалува товарот од рамената и го пренесува на колковите (95\%). Оваа иновација нуди повеќе предности во однос на класичниот ранец: нуди целосна слобода на движење, едноставна за користење, носење без напор, нема потење и директен контакт на ранецот со телото, го намалува товарот врз рамената.
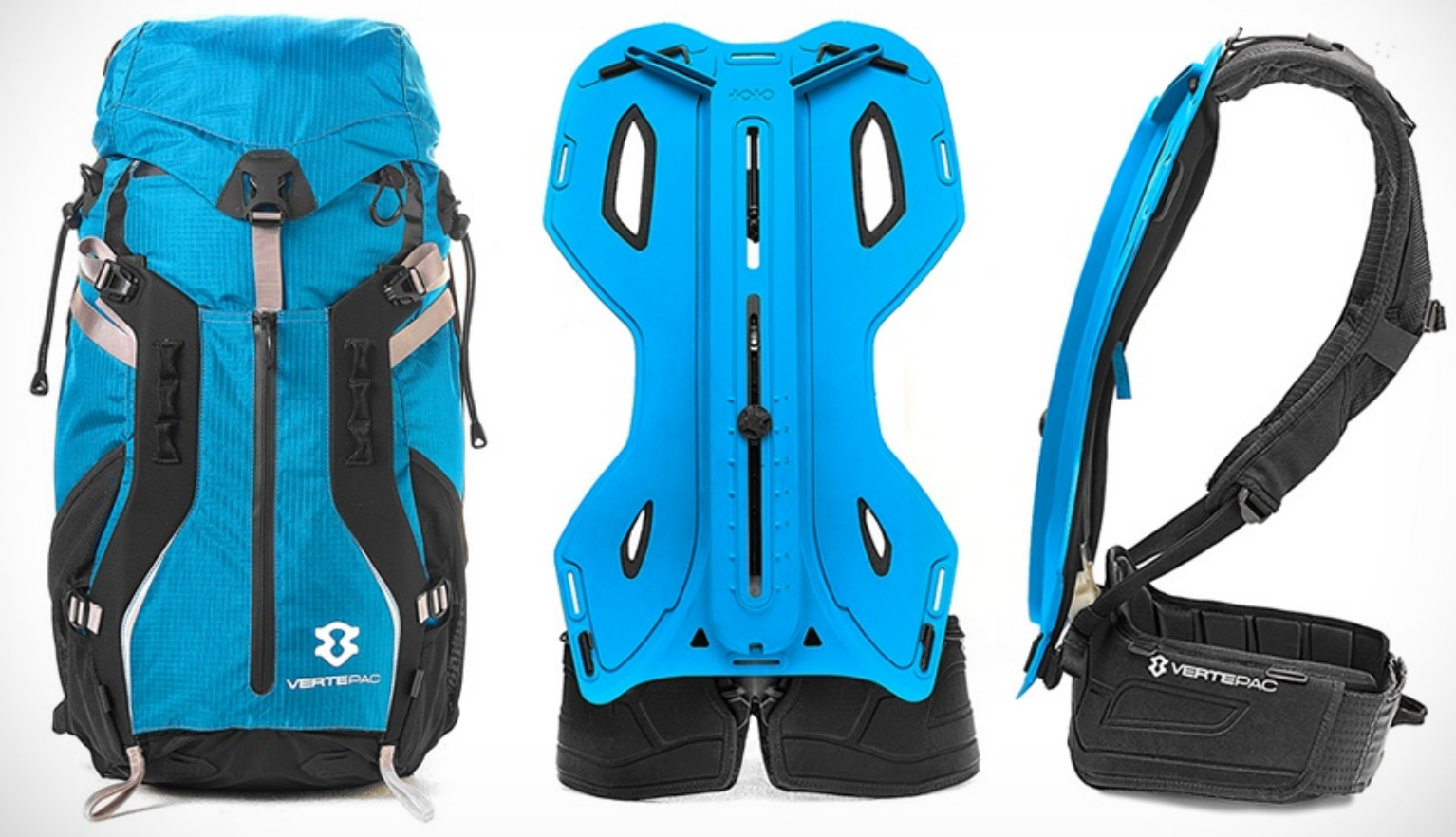

Слика 5.5 VERTEPAC вештачки рбет 


\section{6. МАТЕРИЈАЛИ ЗА ИЗРАБОТКА НА РАНЦИ}

Кога се работи за некој производ, за да може да се дефинираат материјалите треба да се знае кои карактеристики треба да ги исполнува материјалот. Ранците спаѓаат во група на производи каде не се експериментира премногу со изборот на материјалите и не постои голема разлика во основниот материјал од минатото до денес.

Секој ранец е поделен на неколку делови (склопови) кои понатаму се составуваат да се добие една целина:

- $\quad$ Преден дел (FRONT)

- Основен дел (BASIC PART)

- Грб (BACK)

- Рамка (FRAME)

- Дно (ВОТТОМ)

Материјалите за изработка не еден ранец се поделени на:

- Основен градбен материјал

- Структурен материјал

- Помошни материјали

Основен градбен материјал е материјалот кој ја фрормира надворешноста на ранецот и без кој неможе да се призведе ранецот. Кај ранецот тој материјал е платното. Треба да исполнува повеќе барања: водоотпорност, цврстина, отпорност на абење, да биде лесен, да може да се обработува, да биде константен при температурни промени, висок квалитет.

Структурен материјал е материјалот кој ја фрормира структурата на ранецот и му ја дава фрормата, може да се наоѓа во внатрешноста (сокриен) или надворешен, да биде видлив. Треба да биде лесен, да има цврстина и да може да се обработува.

Помошни материјали се сите материјали кои ја прават целината на ранецот и овозможуваат негова функционалност. Како помошни материјали се користат: Постава, мрежа, пластични/ метални додатоци, патент, конец, траки, разни типови на пена, гумени додатоци, метални/ карбонски додатоци 


\section{1 Полиетилен}

Полиетилен или политен (кратенка РЕ) е најчесто употребуваната пластика. Нејзината примарна употреба е во пакувањето (пластични кеси, пластични фрилмови, геомембрани, контејнери вклучувајќ шишиња итн.). Многу видови на полиетилен се познати, а повеќето имаат хемиска формула $\left(\mathrm{C}_{2} \mathrm{H}_{4}\right) \mathrm{n}$. Својствата на полиетиленот може да се поделат на механички, хемиски, електрични, оптички и термички својства.

$>$ Механички својства

Полиетиленот е со ниска цврстина и отпорност, но има висока еластичност и сила, како и ниско триење. Покажува голема цврстина под дество на континуирана сила, што може да се намали со додавање на кратки фибер влакна.

\section{> Термички својства}

Примената на полиетиленот е ограничена со точката на нејзино топење од $80^{\circ} \mathrm{C}\left(176^{\circ}\right.$ F) (HDPE, типови на ниски кристален омекнува порано). За полиетилен со средна и висока густина, точката на топење обично е во опсегот од 120 до $180^{\circ} \mathrm{C}\left(248\right.$ до $356^{\circ} \mathrm{F}$ ). Точката на топење на средниот, комерцијален, полиетилен со ниска густина е типично $105-115^{\circ} \mathrm{C}$ (221 до $239^{\circ} \mathrm{F}$ ). Овие температури варираат со типот на полиетилен.

$>$ Хемиски својства

Полиетиленот се состои од неполарни, заситени, високо молекуларни јаглеводороди. Затоа, неговото хемиско однесување е слично на парафин. Поединечните макромолекули не се ковалентно поврзани. Поради нивната симетрична молекуларна структура, тие имаат тенденција да кристализираат; целокупниот полиетилен е делумно кристален. Повисоката кристалиност ја зголемува густината и механичката и хемиска стабилност.

Полиетиленот речиси не апсорбира вода. Пропустливоста на гасот и водата (само поларните гасови) е пониска отколку кај повеќето пластики; кислород, јаглероден диоксид и ароми, од друга страна може лесно да го помине.

Полиетиленот полека гори со син пламен со жолто врвче и дава мирис на парафин (сличен на пламенчето на свеќата). Материјалот продолжува да гори при отстранување на изворот на пламенот и капе.

> Електрични својства

Полиетиленот е добар електричен изолатор. 


\section{Оптички својства}

Во зависност од термичката историја и дебелината на филмот, РЕ може да варира помеѓу јасно (прозирно), млечно-матно (прозирно) или нетранспарентно. LDPE поседува најголема, LLDPE малку помала и HDPE е најмала транспарентност. Транспарентноста се намалува со кристали, ако се поголеми од брановата должина на видливата светлина.

> Класификација

Полиетиленот е класифициран по својата густина и разгранување. Неговите механички својства значително зависат од варијаблите како што се степенот и видот на разгранетоста, кристалната структура и молекуларната тежина. Постојат повеќе видови на полиетилен.

Во конкретниот дизајн на ранци најинтересна за примена е технологијата на Попречно поврзан полиетилен PEX или XLPE Полиетиленот со вкрстени врски е одличен за различни апликации. Со природната отпорност на мувла, како и отпорноста на вода и дамки, оваа пена е одлична за постигнување атрактивен изглед кога се користи за пакување. Исто така, може да се користи и за уреди за флотација, индустриски уреди и за употреба во градежништвото.

Овој хемиски преоден полиетиленски раствор е со екстремно фина-клеточна опција која го прави идеален за области и проекти за кои е потребна густа, цврста пена.

Овој материјал со затворени ќелиии нуди најдобри карактеристики за ригидност, издржливост и перформанси. Освен тоа што е функционална и со високи перформанси, оваа пена е исто така отпорна на абење, па затоа е практично неуништлива. Исто така е дизајнирана да биде отпорна на повеќето хемикалии за да се избегнат дамки или оштетувања. Најбитно од сѐ, пената не е токсична. Дизајнирана е да биде супер издржлива исто така има мазна, пријатна површина што ја прави привлечна за места каде пената ќе биде видлива. Овој вид полиетилен може да се рециклира, термоформира и е лесен.

\section{2 Платно}

Платното е главен материјал за производство на ранец. Постојат многу видови на платно со различни карактеристики, различни градбени материјали и за различни намени. Кај ранците за планинари кои постојат на пазарот најчесто се применети POLYESTER, CORDURA и POLYAMID (најлон) платно. Платното мора да исполнува низа карактеристики за да може од него да се изработуваат ранци за планинарење. Цврстина 
се добива при самото ткаење на платното која зависи од дебелината на фриламентот од кој се ткае и густината на ткаење.

Постојат различни типови на платно, а најчесто употребувани за ранци ce: 400D, 500D, 600D, 1050D, 1680D бидејќи имаат добра цврстина, издржливост и прифатлива цена.

Густината на ткаењето помага да се објасни дебелината на платното и се изразува во $\mathrm{g} / \mathrm{m} 2$. Тоа покажува колку филамент е потрошен на m2. Дениер (D) е мерка со која се изразува линеарна маса на густина на влакното (fiber) и претставува маса во грами на 9000m должина на влакното.

Кога треба да се направи одлука какво платно да се употреби за производот, најчесто се прави избор на основа на барањата кои треба да ги исполни платното.

Подолу е дадена табела 6.1 на најчесто користени платна и е направен тест на цврстина:

\begin{tabular}{|l|l|}
\hline Description & Strength in Newton (N) \\
\hline 1680D Nylon/PU & 475.8 \\
\hline 1680D Polyester/PU & 338 \\
\hline 1050D Nylon/PU & 291.7 \\
\hline 1050D Cordura/PU & 285.7 \\
\hline 500D Nylon & 186.7 \\
\hline 600D 64T Polyester/PVC & 302.7 \\
\hline 600D 84T Polyester/PU & 127.4 \\
\hline 400D Nylon & 68.8 \\
\hline 16oz Canvas & 72.4 \\
\hline 12oz Canvas & 32.4 \\
\hline
\end{tabular}

Табела 6.1: Цврстина на платно

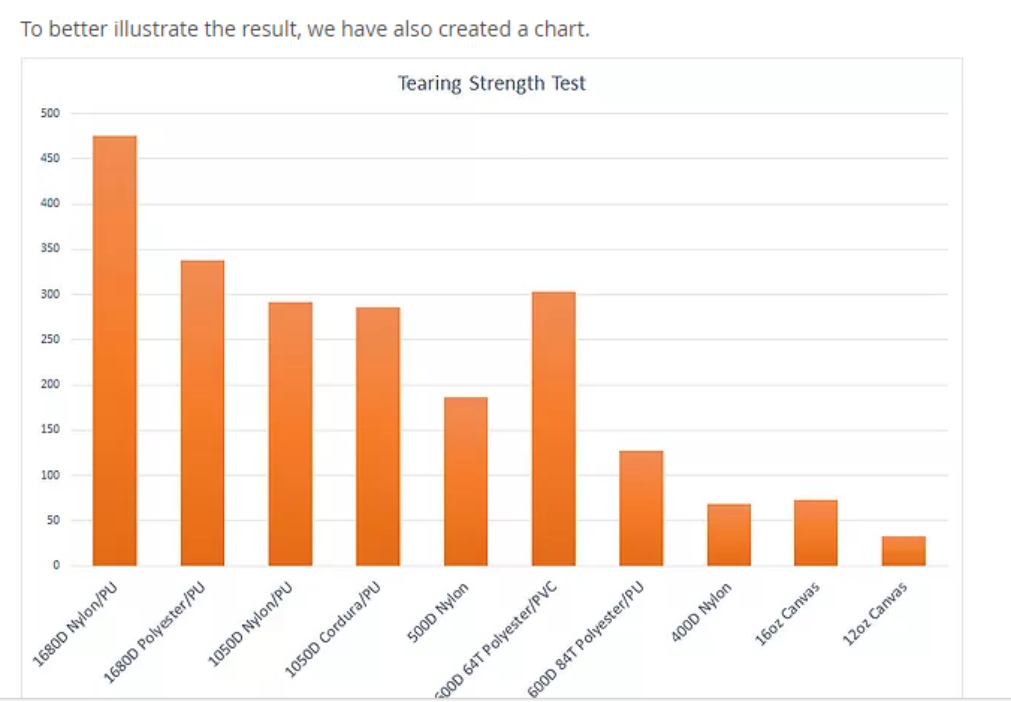

Табела 6.2 : Отпорност на абење на платно 
Од табелата 6.2 погоре се забележува дека најдобра цврстина покажува платното 1680D NAYLON co PU подлога. Повисоките вредности значат поголема цврстина. Од табелата исто така се забележува дека платното изработено од материјал NAYLON e поцврсто од POLYESTER платното. CORDURA платното е синоним за најцврсто платно.

Само на основа на оваа табела не може да се утврди дали најцврстиот материјал е најдобар избор. За да се избере најсоодветен материјал за ранец многу важна е и отпорноста на абење. Отпорноста на абење се тестира преку метод MARTINDALE (SATRA TM-31-2003) со триење од 12kРа на суво платно со 25.600 циклуси.

Резултатот е следен:

600D PES: Умерена абразија

500D NAYLON: Многу мала абразија

1050Д NAYLON: Многу мала абразија

Овој тест покажува дека при нормално користење, овие материјали покажуваат одлични резултати на абење.

Од ова може да заклучиме дека платното изработено од NAYLON е поквалитетно од POLYESTER платното. Од друга страна, платното обложено co PU подлога е подобро отколку PVC.

\subsection{Curv ${ }^{\circledR}$}

Термопластичен композитен материјал од новата генерација. Нов материјал изработен од полипропилен кој е комбинација на 100\% термопластичен материјал со високи перформанси и композит кој е армиран со влакна. Голема тврдост, висока затегнувачка цврстина и извонредна отпорност на удар при мала густина се извонредните својства на овој материјал.Curv® e извонреден материјал кој ја комбинира флексибилноста на 100\% термопластичен материјал со високи перформанси на композит кој е армиран со влакна. Достапен во различни бои Curv® нуди извонредна естетика со тежина половина од тежината на материјалите засилени со стаклени влакна и експоненцијално поголема отпорност на екстремни температури.

Технологијата зад Curv®

Во уникатен и патентиран процес, изработените термопластични ленти се загреваат под притисок за селективно да се стопи надворешноста на лентите, поврзувајќи ги лентите заедно и резултира со композит со силен молекуларен континуитет помеѓу фазите. 
Карактеристики:

- Мала тежина поради извонредната ниска густина од $0,92 \mathrm{~g} / \mathrm{cm}^{3}$.

- Материјал отпорен на удари, без потреба од дополнително засилување.

- Отпорност на екстремни температури (Curv® останува нодуларен на температури многу под стаклената транзициона температура на полипропилен $\left(0^{\circ} \mathrm{C}\right)$.)

- Curv® e 100\% полипропилен, материјал кој е широко признаен како нетоксичен и високо отпорен на корозија. Полипропиленот е исто така отпорен на масла и органски растворувачи.

\section{Естетика}

- Curv® има природен, високо-технолошки изглед. Совршен за модерни дизајни, но безвременски, стандардната површина на ткаенината има изглед на композитен карбон-фибер. Curv® доаѓа во голем број бои и завршни површини.

- Термоформирање, е најчест метод за обработка на овој материјал

- Рециклирање, Curv® e 100\% полипропилен и 100\% може да се рециклира. Ова е значајна еколошка предност во однос на алтернативни, материјали засилени со влакна.

\section{4 Процес на обработка (Термоформирање)}

Термоформирање е производен процес во кој плочи од пластичен материјал се загреваат, а потоа се обликуваат во посакуван облик со примена на различни техники: пресување, вакумирање и дување. За секоја од овие техники потребни се дрвени, пластични или метални алати.

Термоформирање се користи за пластични материјали кои доаѓаат во форма на плочи. Оваа техника се користи за добивање на отворени форми кои понатаму се доработуваат. Оваа технологија е многу малку застапена во производството на ранци и производи кои се изработуваат од платно. 


\section{7. НОВИ ТЕХНОЛОГИИ КОИ МОЖАТ ДА ДАДАТ ПРИДОНЕС ВО РЕШАВАЊЕ НА ЗАДАДЕНИТЕ ДИЗАЈНЕРСКИ ЦЕЛИ}

Современите технологи во областа на обновливи извор на енергија, мехатронички иновации, паметни материјали итн. можат да бидат инспирација за иновативни дизајнерски решенија кај сите видови производи, вклучувајќи ги и ранците. Во продолжение се дадени неколку актуелнииновации кои можат да бидат применети во решавање на конкретниот дизајнерски проблем.

\section{1 Ранец со суспендирани оптоварувања}

Ранец кој генерира сопствена електрична енергија[41] наскоро може да им овозможи на спасувачите, истражувачите и војниците полнење со електрична енергија на нивната опрема додека се во движење.

Пронајдокот, познат како ранец со суспендирани оптоварувања, овозможува полнење на батериите на рачни компјутери, мобилни телефони и десетици други уреди. Лоренс Рим, [42] биолог на Универзитетот во Пенсилванија во Филаделфија, е пронаоѓачот кој го развил уредот за полнење на батерии. Овој пронајдок е базиран на принципот на кој функционираат мускулите во текот на одењето и трчањето.

Уредот обезбедува најмалку 7Wкои се доволни за напојување на неколку електронски уреди во исто време, вклучувајќи мобилен телефон, MP3 плеер, рачен компјутер, очила за ноќно гледање и прочистувач на вода.

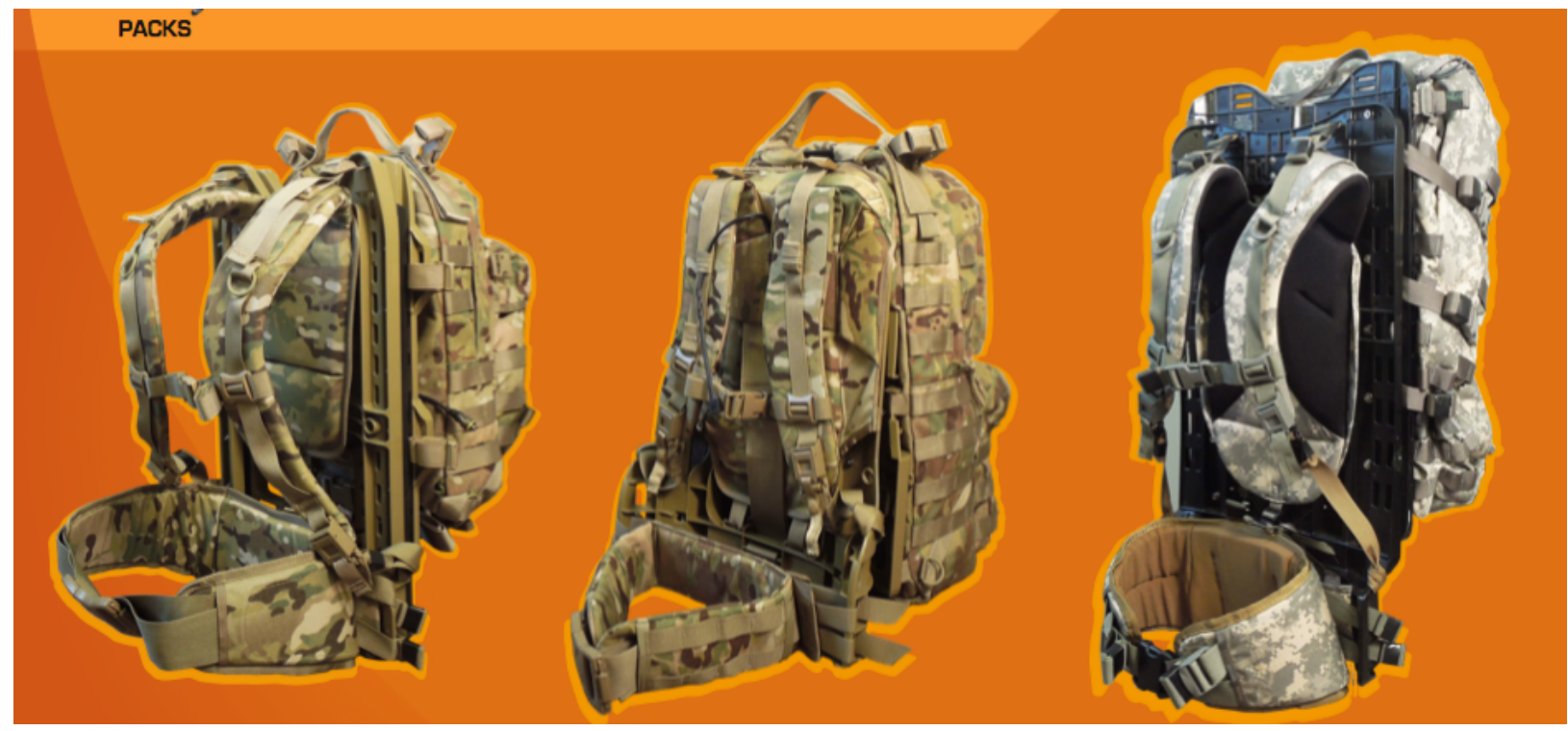

Слика 7.1: Ранец со суспендирани оптоварувања 


\section{2 Ранец кој генерира енергија}

Ранец кој генерира електрична енергија (слика 7.2) обезбедува обновување на енергијата која може да се употребува за тешко пристапни терени и изолирани локации.

Предизвикува поместување на товарот во насока горе-долу од 5-8цм (слика 7.3) со секој направен чекор движењето се конвертира во енергија

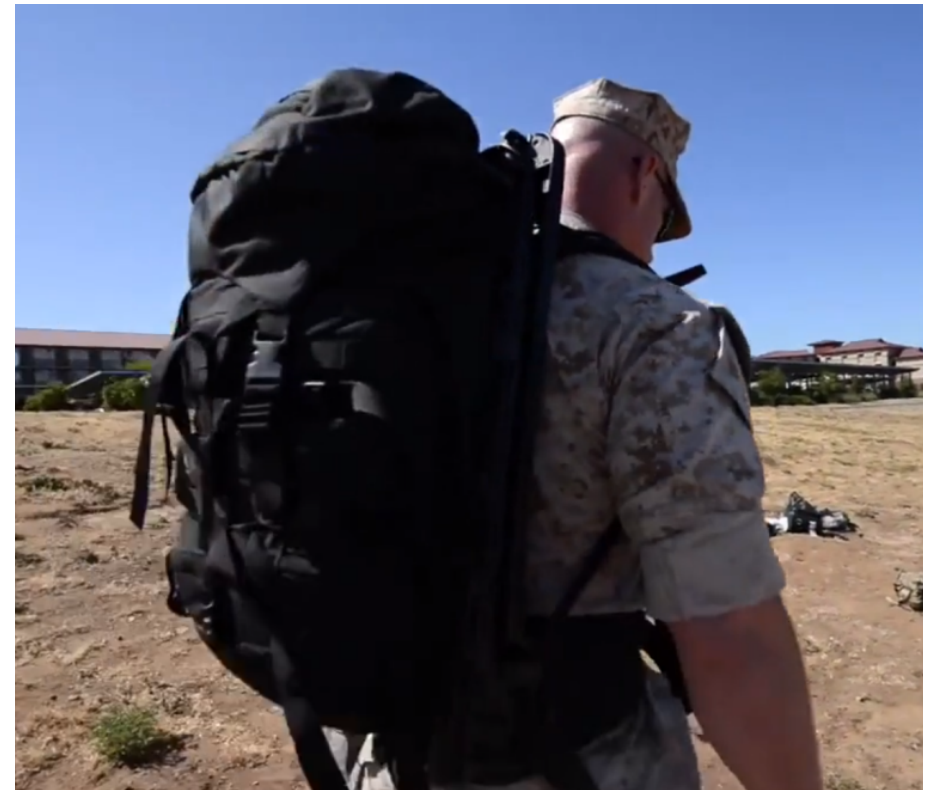

Слика 7.2 Ранец кој генерира енергија

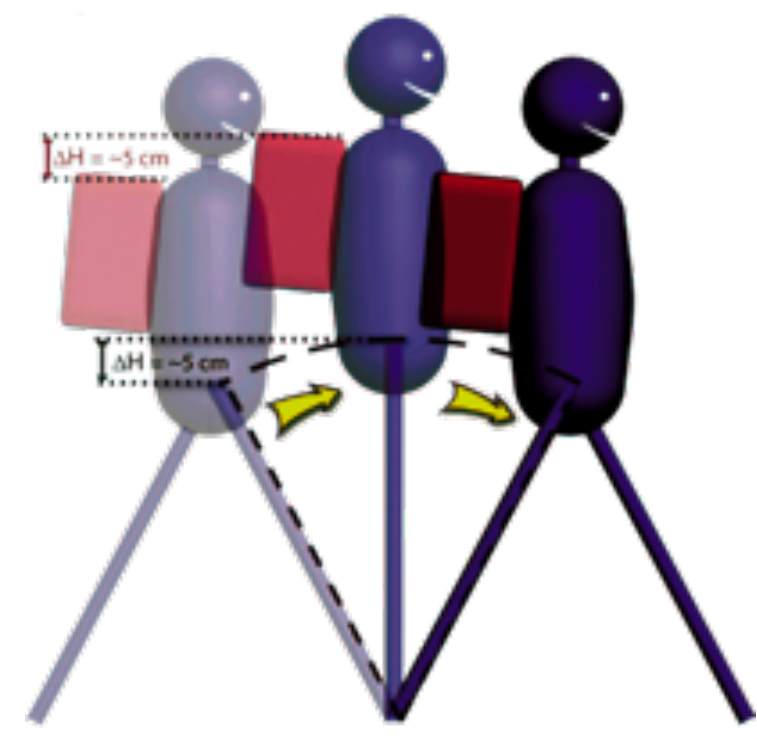

Слика 7.3 Поместување на ранецот при движење

За 23кг на товар

\begin{tabular}{|l|l|}
\hline Активност & Просечна електрична моќ \\
\hline Релаксирано одење & $12-15 \mathrm{~W}$ \\
\hline Брзо одење & $20-35 \mathrm{~W}$ \\
\hline Трчање & $33-40 \mathrm{~W}$ \\
\hline Рачно пумпање & $30-50 \mathrm{~W}$ \\
\hline
\end{tabular}

Табела 7.1: Производство на електрична струја при различни начини на активност 


\section{3 Егзоскелет}

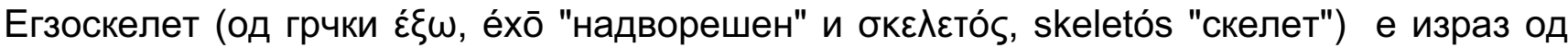
биологијата кој се однесува на надворешниот скелет што го поддржува и заштитува телото, за разлика од внатрешниот скелет (ендоскелет). Некои од поголемите приемри на егзоскелети се познати како "школки".

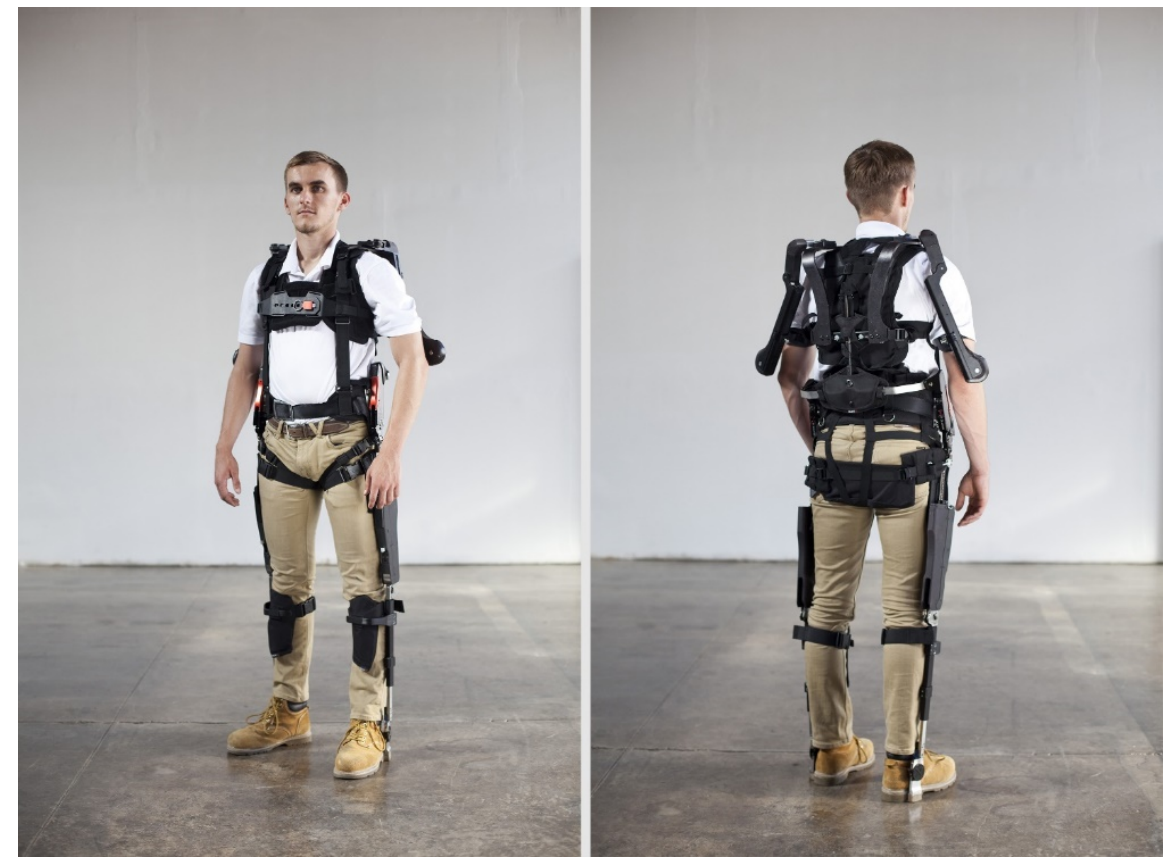

Слика 7.4 Егзоскелет за подршка на човеково тело

Примери за животни со егзоскелети вклучуваат инсекти како што се скакулци, лебарки, ракови и јастози. Некои животни, како што е желката, имаат и ендоскелет и егзоскелет. Дефиниција на егзоскелет е круто надворешно покривање на телото кај некои без'рбетници, особено членконоги, кое обезбедува поддршка и заштита.

На сликата 7.4, е прикажан егзоскелет кој е наменет за поддршка на човековото тело. Во овој случај, едноставно се зголемуваат човечките ффизички способности со примена на технологија, машинерија. Употребата на егзоскелет може да биде корисна во:

- Воена индустрија

- Цивилна индустрија

- $\quad$ Здравството (здравственаиндустрија)

\section{EXO HIKER}

Постојат огромен број на скици и планови за концепт решенија и истражувања за ранци за планинарење. Главниот фокус на сите модели е во комбинирање на технолошки додатоци со една цел - да може да се пренесе што поголема тежина без поголеми напори и замор. 
Една таква истражувачка дејност работи BERKELEY ROBOTICS AND HUMAN ENGINEERING LABORATORY каде се прават огромен број на истражувачки активности кои се фокусирани на дизајн и контрола на роботички ситеми што ги носат луѓето за да ја зголемат механичката сила. Нивни најпознати проекти од оваа област се: BLEEX, EXOHIKER, EXOCLIMBER, HULC и AUSTIN.

Ранецот EXO HIKER (слика 7.5 и слика 7.6) кој е дизајниран со надворешна рамка и е поврзан со егзоскелет има една цел - носење на голем товар за долги пешачења. Има вградено електромотори, компјутер и генератор.

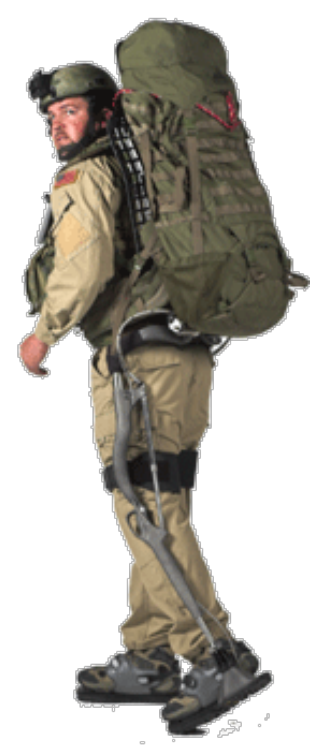

Слика 7.5 EXO HIKER ранец

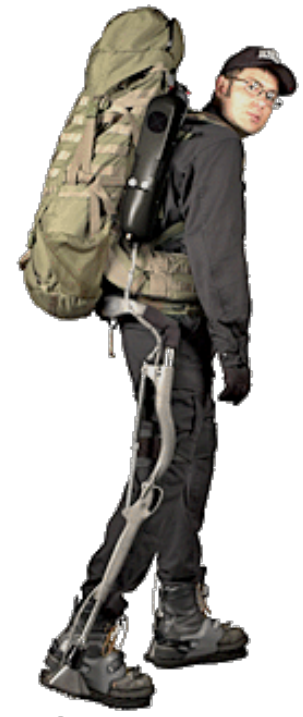

Слика 7.6 EXO HIKER ранец

\section{Карактеристики на моделот EXO HIKER}

Тежина: 14кг., вклучувајќи и батерии, генератор за струја и компјутер

Носивост: 68кг. без чувствување на оптоварување

Времетраење: Без монтиран сончев панел може да се користи 68км без престан, со соларен панел за полнење на батериите времето може да биде неограничено.

Пример: Поради технологијата за испорака на енергија, батерија со 8W/h која тежи 1,2кг. е доволна да го напојува овој егзоскелет за носење на 68кг. оптоварување за 21 час, без носителот да чувствува оптоварување на рамото.

Интерфејс: Мал рачен LCD екран.

Посебни карактеристики: лесен за пакување, брзо излегување од ранецот и егзоскелетот во случај на опасност. 


\section{4 Ергономски ранци}

Овој ергономски ранец (слика 7.5) користи јажиња со кои се регулира оптоварувањето на рамената. Јажињата го суспендираат оптоварувањето од ранецот, така што останува на иста висина од тлото, додека корисникот се движи и со тоа ги намалува ризиците од мускулни проблеми. Дизајниран е за носењето на тешки товари. Негова цел е товарот да стане полесен. Дизајнерите од компанијата LIGHTNING PACKS LLC велат дека на корисниците ќе им овозможи да носат дополнителни бкг додека трошат исто количество енергија како да носат нормален ранец. Новиот ранец го намалува вертикалното поместување на товарот (Слика 7.7).

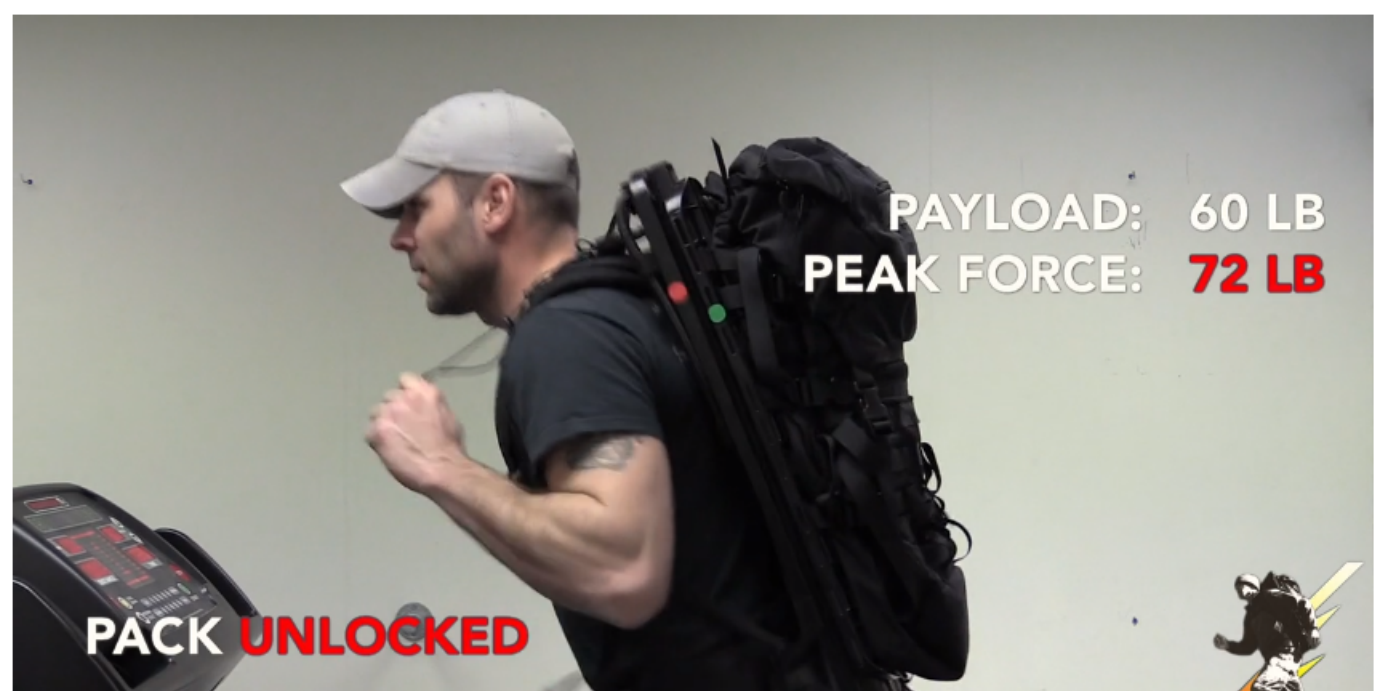

Слика 7.7 Ранец со механизам за редуцирање на тежината

\section{5 Соларни ќелии}

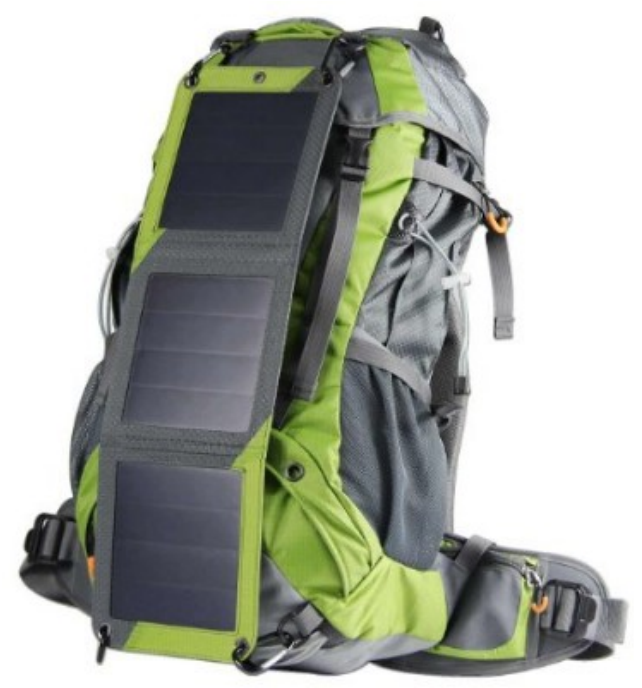

Сончевата енергија е идеален извор на енергија, достапна насекаде на планетата и неисцрплива. Нејзиното искористување е можно преку соларни ќелии.Соларните ќелии се полупроводнички структури кои го конвертираат сончевото зрачење во високо-бранова фрекфенција, електрична енергија. Соларните панели се изградени од повеќе слоеви. Првиот слој е заштитно силициум стакло, кое ја штити ќелијата од надворешни влјанија.

Слика 7.8 Ранец со соларни ќелии 
Под него се наоѓa антирефлектирачка површина која ја смалува рефрлексијата на светлината и обезбедува што поголемо количество енергија да влезе во полупроводникот. Потоа доаѓа систем на транспарентни електроди и на крајот од долната страна се наоѓа метализација или долен контакт.

Максималниот излезен напон на една индивидуална соларна ќелија изнесува $600-700 \mathrm{mV}$, па затоа ќелиите се поврзуваат сериски како би се добил посакуваниот напон.

Компанијата SOLBIAN од Италија има произведено панели кои се преносливи, фрлексибилни и компактни. Тиеимаат вградена комплетна електроника и батерија (ALL IN ONE), поради што постои можност да се вградуваат во разни производи и се многу лесни за користење.Зафаќа малку место, има мала тежина, а нуди полнење на енергија секаде каде што има доволно сончева енергија. Енергијата може да се користи за полнење на мали електронски уреди како: мобилни телефони, таблети,ГПС уреди и сл.

При константна сончева светлина, 12W панел обезбедува 2A струја, што е доволно за целосно полнење на мобилен телефонза еден час и полнење на повеќе моќни уреди. 


\section{8. АНАЛИЗА НА ПАЗАРОТ}

\section{1 Анализа на постоечки производи на пазарот}

Денес на пазарот има огромен избор на ранци за планинарење. Според дизајнот и материјалите од кои се изработуваат се гледа дека сеуште е задржан оној конвенционален дизајн на опрема за планинарење. Најголемите вложувања се во изборот на материјали и ергономскиот развој на задниот дел на ранецот (грбот).

Ранците кои се достапни на пазарот се премногу комплицирани за изработка, имаат голем број на прегради, механизми за отворање и слично. Околу $90 \%$ од изработката на овие ранци е рачна работа, за која се потребни огромен број на работници.

Мултифункционалноста кај постоечките ранци се базира на обичен ранец со вграден сончев панел за полнење на батерија, ранец со мобилни прегради за организација на просторот, различни додатоци кои се импортирани како додаток за вода, компас, термо прегради и слично. Постојат и друг вид на ранци кои сеуште се во фраза на развој и се користат исклучиво за професионални цели, произведуваат самостојно електрична енергија од кинетичката енергија при движење, ранци кои се состојат од повеќе компоненти и имаат додаток за р'бет, со вградени чадори, со вградени аларми против кражба, со вграден ГПС, со заштитни механизми за отворање и друго.

Постојат голем број на ранци за планинарење на пазарот кои се разликуваат по многу карактериситки, како материјалот од кој се изработени, волумен и тежина. Последните години се посветува огромно внимание и се прават истражувања за материјалите од кои ќe ce изработуваат ранците и квалитетот на изработка. Оваа опрема се купува за специјална намена и мора да биде изработена од врвни материјали. Најголемо внимание се посветува на тежината на ранецот и сите најголеми фирми од оваа област се натпреваруваат кој ќе направи полесен ранец, а со одличен квалитет. Производството на ранци на сите најголеми компании за ранци е сместено во Кина и Виетнам.

Подолу се прикажани најдобрите 3 ранци за планинарење за 2018г. според најпосетуваниот сајт за планианрење CLEVERHIKER.

\subsubsection{HMG 2400 \& 3400 Southwest}

Компанијата Hyperlite Mountain Gear создаваат извонредна рамнотежа помеѓу тежината, отпорноста на временски непогоди и издржливоста. Овие раскошни ултралесни ранци имаат минималистички дизајн, а нивните нараменици се многу ефикасни и се чувствуваат поцврсти од повеќето лесни пакувања. Уникатната DCF ткаенина и скриените рабови го прават овој ранец многу издржлив и целосно водоотпорен. 
Најголем недостаток е нејзината повисока цена поради DCF ткаенината, но овој ранец ќe трае многу години и илјадници милји патеки ако се чува и одржува со внимание.

Ранец број 1 според CLEVER HIKER за 2018г.

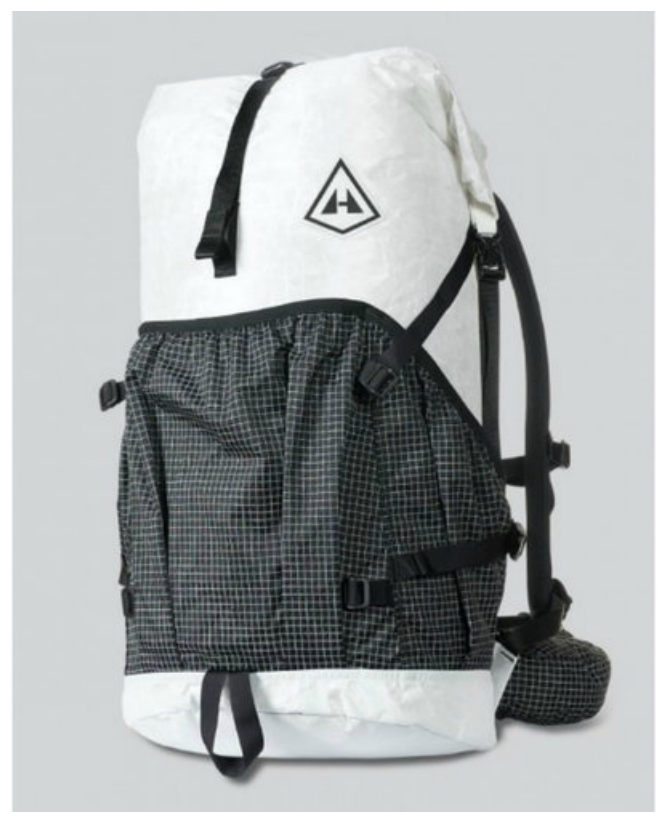

Тежина: 500грама

Волуемен: 40L / 55L

Носивост: 18кг.

Слика 8.1 Ранец HMG 2400

\subsubsection{Gossamer Gear Gorilla 40}

Тоа е добро дизајниран, издржлив и удобен ранец со сите детали кои се вградени внатре. Има униформиран ергономски облик на хип ремен, кој е удобен за мажи и жени и добро се носи со тежината на патеката. Овој ранец има едноставна алуминиумска рамка, добро поставени ленти за на рамо и отстранлив хип ремен. Горниот џеб од Gorilla е исто така ефикасен за складирање на мали предмети.

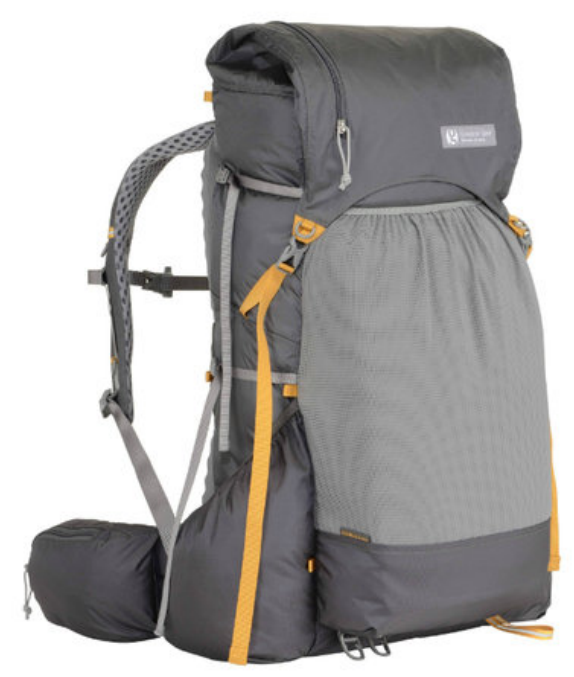

Тежина: 500грама

Волуемен: 40L / 55L

Носивост: 15кг.

Слика 8.2 Ранец GGG 40 


\subsubsection{ZPacks Arc Blast}

Перфектен ранец кој е извонредно погоден за пешаци и туристи кои носат тежина од околу 10 до 15 килограми. Единствената рамка за поставување на овој пакет има заден дел кој овозможува одлична вентилација кога не е преполн. Arc Blast, исто така, има ремени за регулирање според торзото. Пакетот е направен со DCF ткаенина, што го прави многу отпорен на вода, но исто така ја зголемува цената.

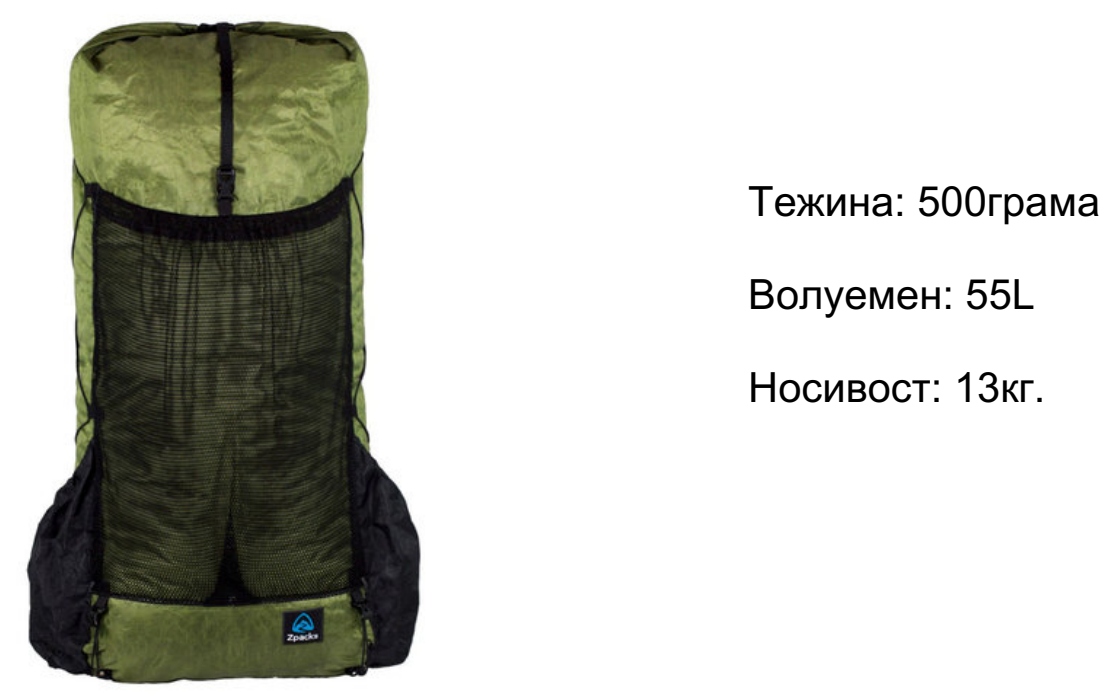

Слика 8.3 Ранец ZPACK

\subsubsection{DEUTER}

Компанијата DEUTER е една од најпознатите и најстари компании за ранци. Развиваат и продаваат високофункционални производи со врвен квалитет. Имаат одлична репутација кај клиентите. Имаат огормен асортиман на производи и посветуваат големо внимание на ергономијата и удобноста на ранците. На нивниот сајт нудат премногу совети за соодветен избор на ранци, големина и совети за правилно пакување. 

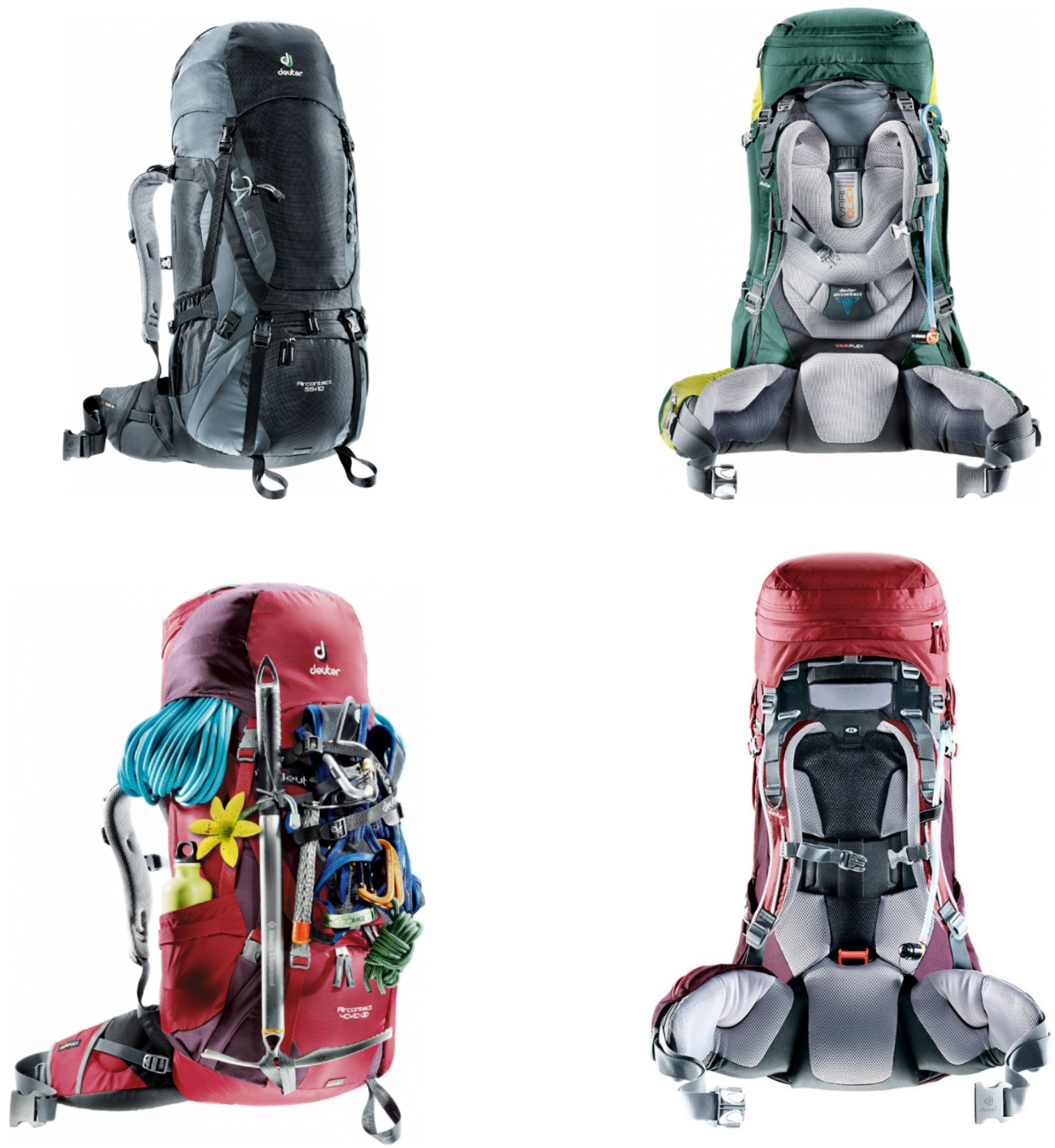

Слика 8.4 Ранец DEUTER AIRCONTACT PRO

\section{AIRCONTACT PRO $70+15$}

Овој модел на DEUTER е најголем во нивниот асортиман.

Тежина: 3,5кг.

\section{Волумен: 85литри}

Во него има простор апсолутно за се. Наменет за тешки и долги патувања. Има голем број на прегради и доволно простор за целата опрема и алатки. Со неговиот дизајн на грбот овозможува подесување на висината на нарамениците за лесно и удобно патување. Истиот има можност за прилагодување за жени. 


\section{2 Анализа на барањата на купувачите}

Според CLEVERHIKER, подолу се дадени основните барања на купувачите на ранец за планинарење.

ЦЕНА - солиден лесен ранец не треба да има превисока цена.

ТЕЖИНА - Ранецот ќе биде еден од четирите најтешки делови што се носат на патувања (ранец, шатор, вреќа за спиење, плоча за спиење), па затоа е важен дел од опремата за намалување на вкупната тежина.

РАМКА - Колку е помала вкупната тежина, толку помала рамка е потребна. Повеќето од ранците имаат едноставни рамки кои се удобни за пренесување на товари до околу 35 килограми.

ВОЛУМЕН - Волуменот на ранецот ограничува колку ќе може да се носи во него. Најискусните планинари може лесно да ја спакуваат нивната опрема во ранец од 40-50 литри, дури и за возење. Исто така, за користење на ранецот за зимски поход, треба зголемување на големината за да се приспособи на тешка и гломазна опрема.

ДИЗАЈН - Ранецот не мора да биде комплексен за да биде исклучителен. Често компаниите кои ги задржуваат елементите на дизајнот едноставни и рационализирани ги прават најдобрите ранци.

МАТЕРИЈАЛ - Повеќето лесни ранци се направени од еден од двата материјали: Ripstop Nylon или Dyneema Composite Fabric. Генерално, DCF е полесен и повеќе отпорен на вода, но исто така е поскап. Двата материјали се издржливи и високо функционални за ранци.

УДОБНОСТ - Удобноста е еден од најважните фрактори за ранец, но исто така е една од најтешките карактеристики што треба да се наведат. Пред да се купи ранец треба да се измери должината на торзото и големината на колкот.

\section{3 Анализа на корисничките потреби за градбата на ранецот}

ОСНОВНА ПРЕГАРАДА - Повеќето лесни ранци имаат еден преграден простор за складирање на поголемиот дел од опремата. Дополнителните прегради и патентите ја зголемуваат непотребно тежината и сложеноста.

ПРЕДЕН ЏЕБ СО МРЕЖА - Повеќето лесни ранци имаат голем џеб од мрежа на предниот дел (страната каде одат луѓе зад вас). Оваа функција е многу корисна.

Одлична за брзо ставање на предмети кои се лесно достапни, како јадење или прочистувач на вода. Исто така е добро за проветрување на влажна опрема. 
ПОЈАСНИК - добар ремен е клучна карактеристика на секој ранец. Појасникот ќе го задржи поголемиот дел од тежината на ранецот на колковите, што ги задржува рамената одморени.

НАРАМЕНИЦИ - Нарамениците имаат значителен придонес за распоредување на тежината. Треба да имаат удобност и да бидат добро распоредени за да се избегнат болки и притисоци.

ЏЕБОВИ НА ПОЈАСНИК - Со лесен ранец нема потреба од толку честоодмарање, така што треба да се има пристап до одредени предмети, како што се закуски, креми за сончање, мелем за усни, камера и др. Повеќето од ранците имаат вградени џебови во појасникот.

ПРЕГРАДА ЗА ШИШИЊА ЗА ВОДА - Хидратацијата е клучна во планинарењето, така што шишињата со вода секогаш треба да бидат лесни за дофат.

ВОДООТПОРНОСТ - Во принцип, не е добра идеја целосно да веруваме во водоотпорност кај било кој ранец. Дури и кај запечатени ранци направени од водоотпорни материјали ќе дојде до мали протекувања со текот на времето, така што секогаш треба да се заштитат важни предмети (вреќа за спиење, облека, електроника итн.) во водонепропустливи вреќи или пластични кеси во ранецот.

ВГРАДЕНИ ДИЗСПЕНЗЕРИ - Пиењето вода од вграденИ диспензери со излезно црево се препорачуваат за секој ранец, бидејќи зафаќаат помалку место

СТЕГАЧИ ЗА ГРАДЕН КОШ - Стернум ременИ (стегачИ за граден кош) се вградуваат во повеќето ранци. Тие даваат опција да се поврзат нарамениците кај градите за посигурно чувство. Попријатно е кога стегачите имаат еластичен дел.

ТРАКИ ЗА ПОДЕСУВАЊЕ НА ТОВАРОТ - Каиши за подигање на товар може да се искористат за повлекување на врвовите на рамената кон ранецот. Ова ќе помести дел од притисокот надолу од нарамениците и ќе се пренесе на предниот дел од рамената и градите. 


\section{9. ГЕНЕРИРАЊЕ НА КОНЦЕПТИ}

Врз основа на претходните истражувања, поставените хипотези и десринираните барања креирани се три различни концепти.

Главна цел: развој на мултифункционален, модуларен ранец за планинарење со максимално искористување на просторот, со цел да собере што повеќе опрема за планинарење, да се пренесува што поголема тежина без да се почувствуваат големи оптоварувања на телото на корисникот.

Целна група: луѓе кои одат на планинарење, но не се доволно физички подготвени да поминат голем пат или пак имаат намалена физичка способност. Тука спаѓаат луѓе кои се љубители на природата и сакаат да истражуваат и да имаат можност да ја следат нивната група која е фризички посилна.

\section{1 Концепт 1}

Концептот 1 е замислен да биде ранец за планинарење кој ќе има две надворешни рамки кои ќе можат да се движат по принципот на суспензија. Вертикалното поместување при одење ќе бидеискористено за произведство на електрична енергија која ќе се складира во батерии кои ќе бидат вградени во ранецот.

Материјалот предвиден за овој концепт е платно од полиамид со цел ранецот да биде што полесен. На врвот на рамката предвиден е дополнителен механизам со чија активација ќe се добие чадор кој е независен и ќе служи за заштита на планинарот во случај на дожд.

Капацитетот на ранецот е планирано да биде 80 литри, поради тоа што голем дел од волуменот ќе заземат батериите.

Дизајнот на ранецот ќе биде конвенционален изработен преку процесот на шиење, грбот мора да биде ергономски и ќе има можности за подесувања за да може да се прилагодува на секој корисник.

Најголем недостаток на овој ранец е неговата маса која ќе биде многу голема поради батериите за складирање на енергија.

Овој концепт ги има следните карактеристики:

- 2 надворешни рамки

- Генерирање на електрична енергија со самото движење

- Материјал најлон платно

- Вграден механизам за покривање при дожд

- Капацитет 80л 
- Ергономски грб

- Голем број на прегради

- Батерии со голем капацитет

- Голема тежина поради батериите кои складираат енергија

- Ергономски појасник

- Конвенционален дизајн

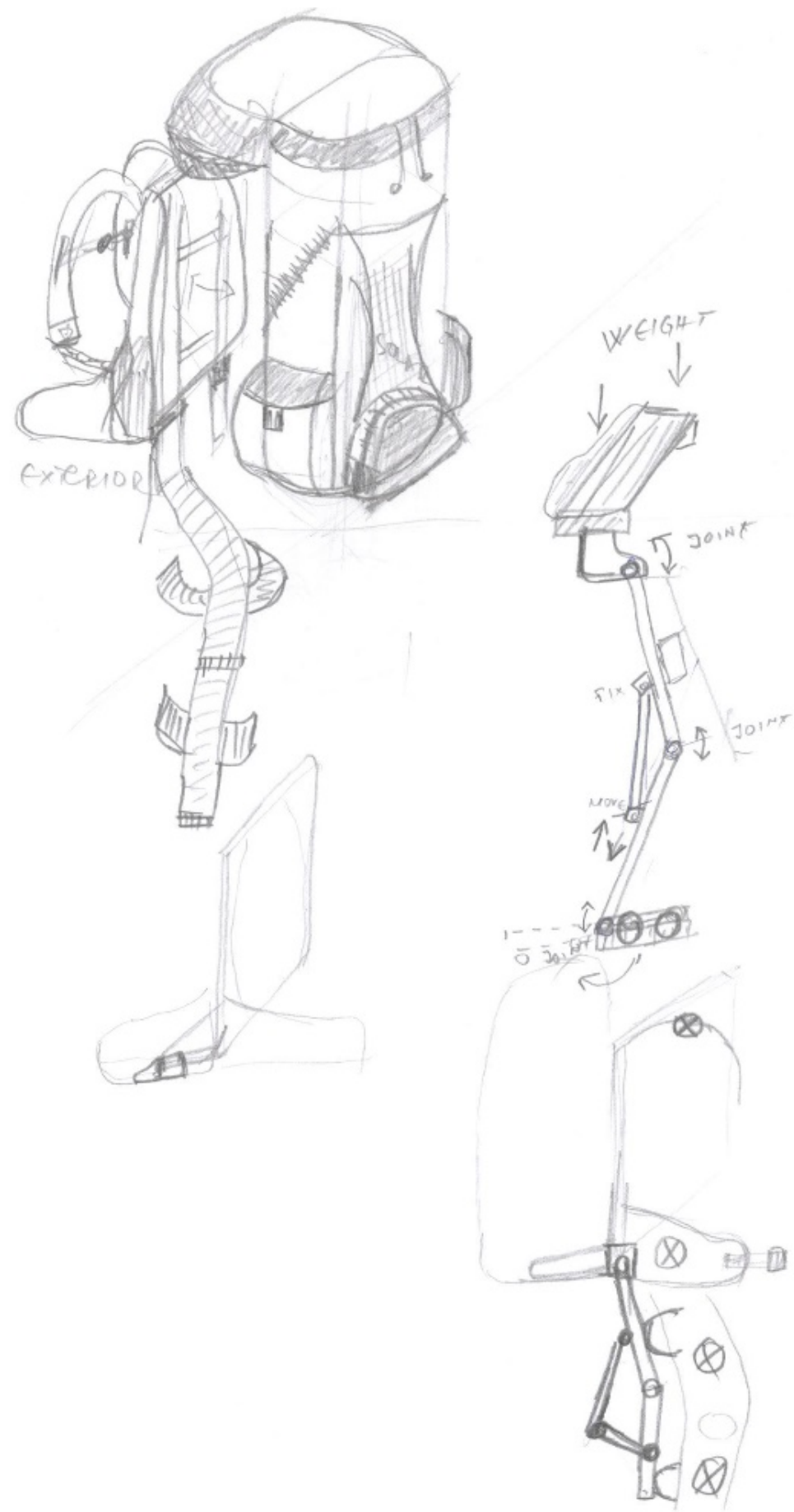

Слика 9.1 Концепт 1 


\section{2 Концепт 2}

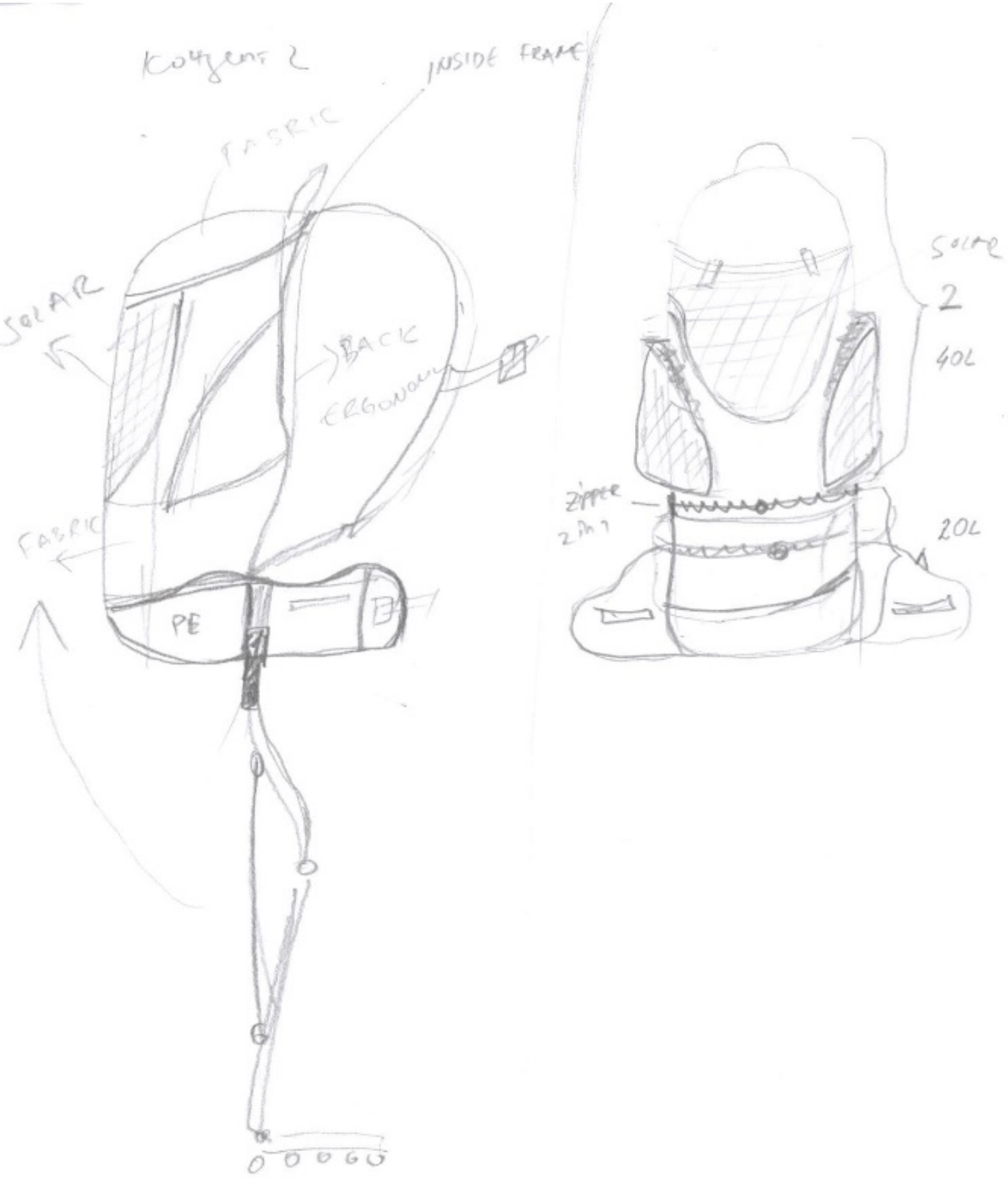

Слика 9.2 Концепт 2

Концептот 2 е замислен како ранец за планинарење кој ќе има внатрешна рамка. Ранците со внатрешна рамка секогаш имаат поатрактивен дизајн поради тоа што рамката е сокриена во внатрешноста и не се гледа. Овој модел е замисленода има на предниот дел голема површина со флексибилни соларни ќелии од системот all - in - one. 
Дизајнот е конвенционален и начинот на изработка е преку процесот на шиење. Грбот секако е предвиден да биде ергономски и со сите можности за подесување за да може да одговара на што поголем број на луѓе. Поради внатрешниот грб капацитетот ќе биде помал околу 65 литри.

Замислено е како додаток да има егзоскелет кој би помагал при носење на поголеми тежини, но единствен проблем тука е тоа што егзоскелетот може да биде само фиксен со електромотори поради внатрешната рамка.Овој конепт ги има следните карактеристики:

- Внатрешна рамка

- Голема површина со соларни панели

- Ергономски грб

- Капацитет 65л

- Материјал најлон платно

- Конвенционален дизајн

- Егзоскелет со електро мотори

- Ергономски појасник

- Мал број на прегради поради сончевите панели

- Мала тежина

- Отворање со патенти

\section{3 Концепт 3}

Концептот 3 е замислен да има две надворешни рамки кои ќе можат да комуницираат една со друга преку вертикална суспензија, каде по желба може да се вклучи механизмот за суспензија на тежината. Преку овој механизам се овозможува значително намалување на тежината од рамената на појасот.

Грбот на ранецот е ергономски и е интегриран на надворешната рамка која е индивидуална и има можност да комуницира со различни типови на ранци. Ергономијата е застапена во сите делови на ранецот, со механизми за подеувања како би одговарала на што поголем број корисници. Во надворешната рамка внатре во каналите предвидено е да има вградено телескопски профрили кои се изработени од материјал CURV и служат за монтирање на конструкција за шатор. 


\section{$\operatorname{SIDE}$}

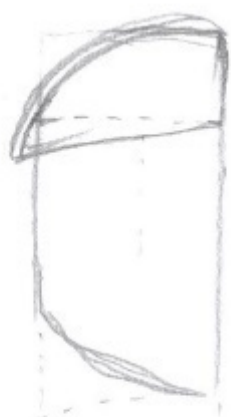

$\Lambda$
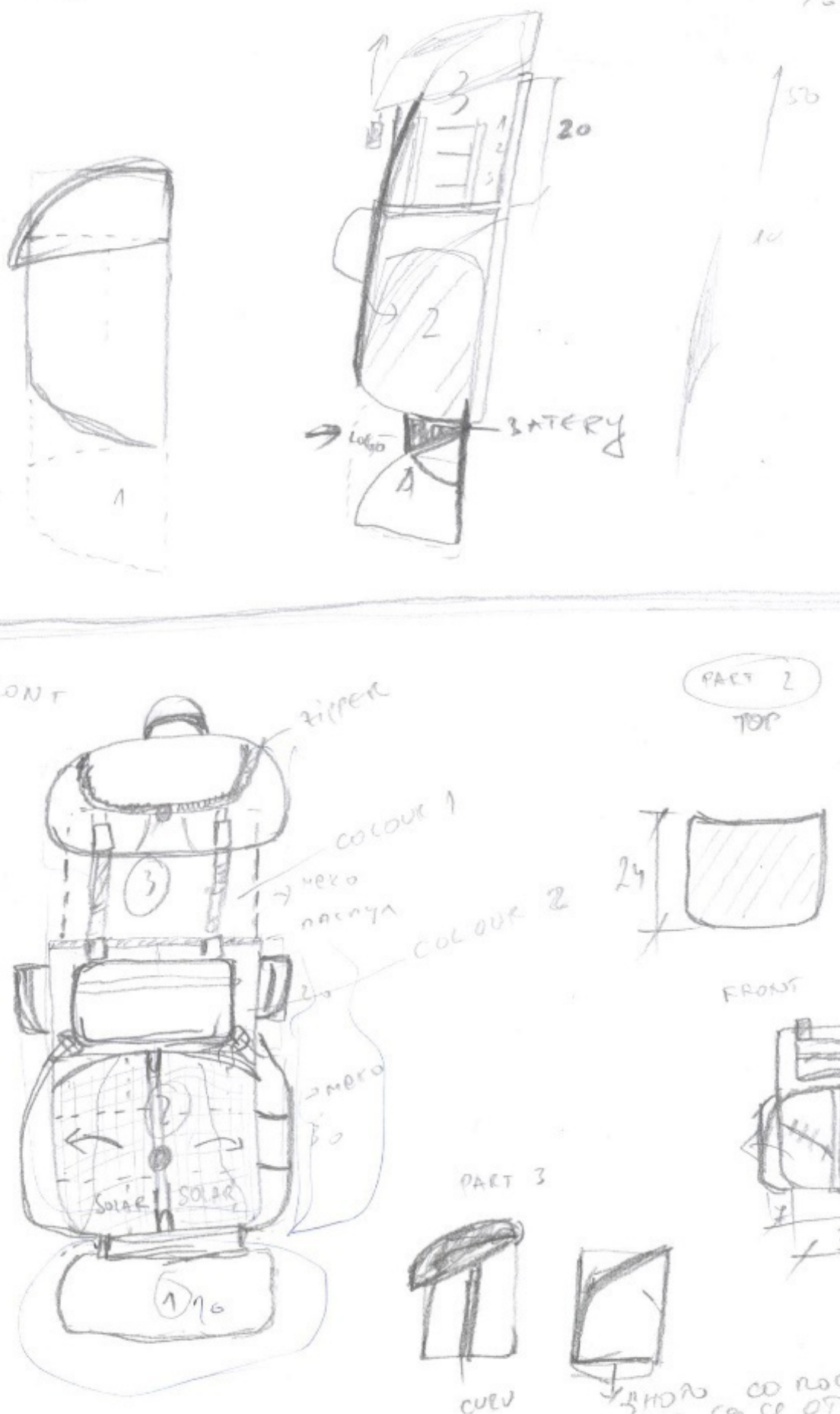

FRowi
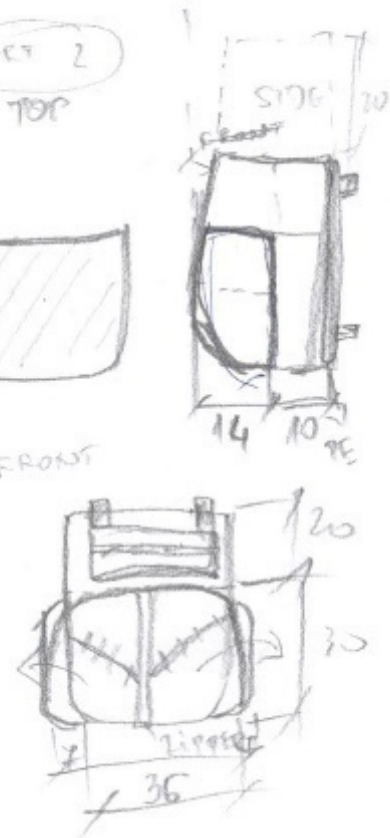

co noen BA 9

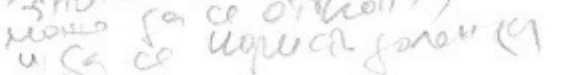

Слика 9.3 Концепт 3 дизајн на модуларен ранец и дефинирање на предниот дел на ранецот 


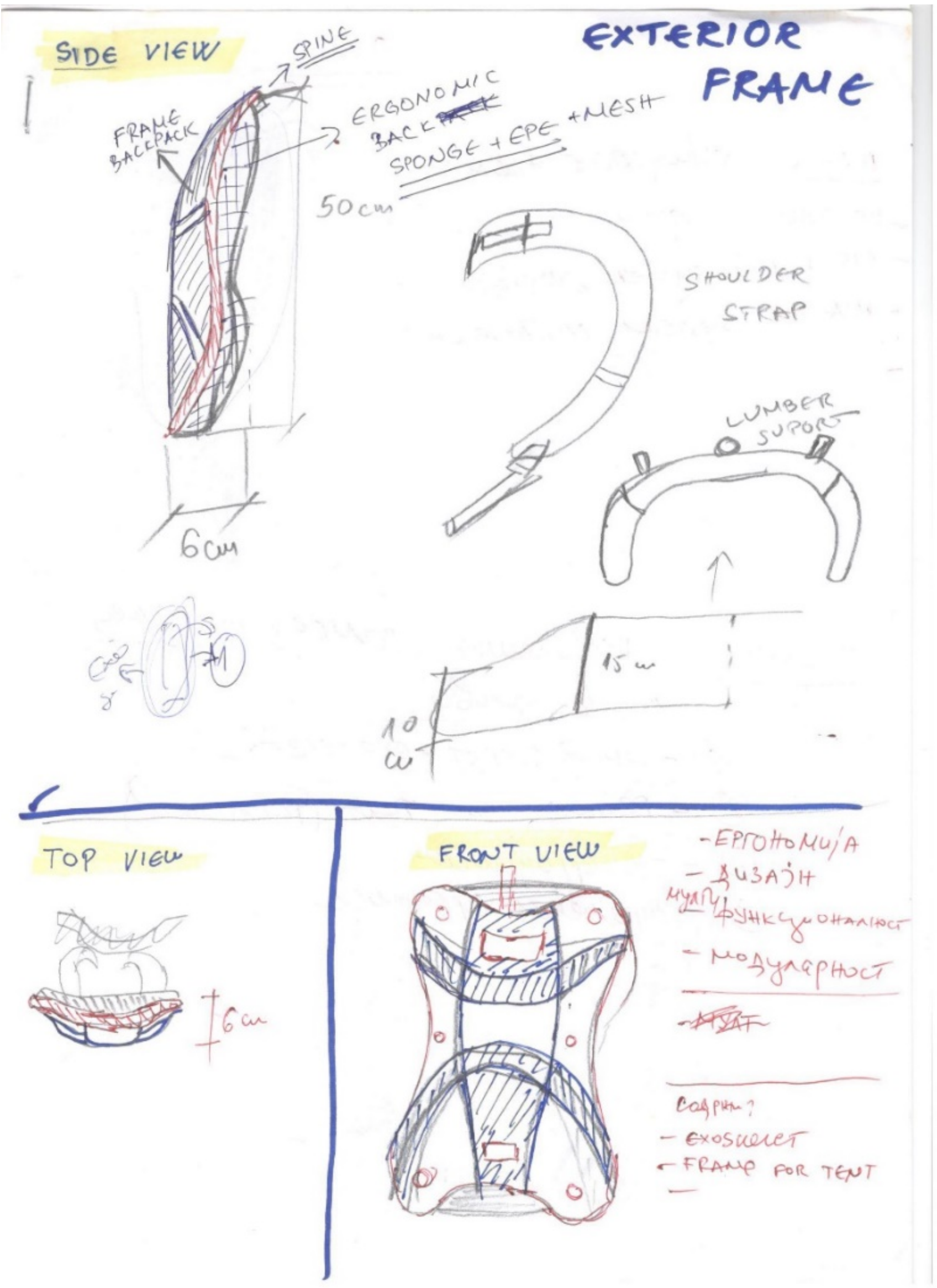

Слика 9.4 Концепт 3 дизајн на нараменици и надворешна рамка 


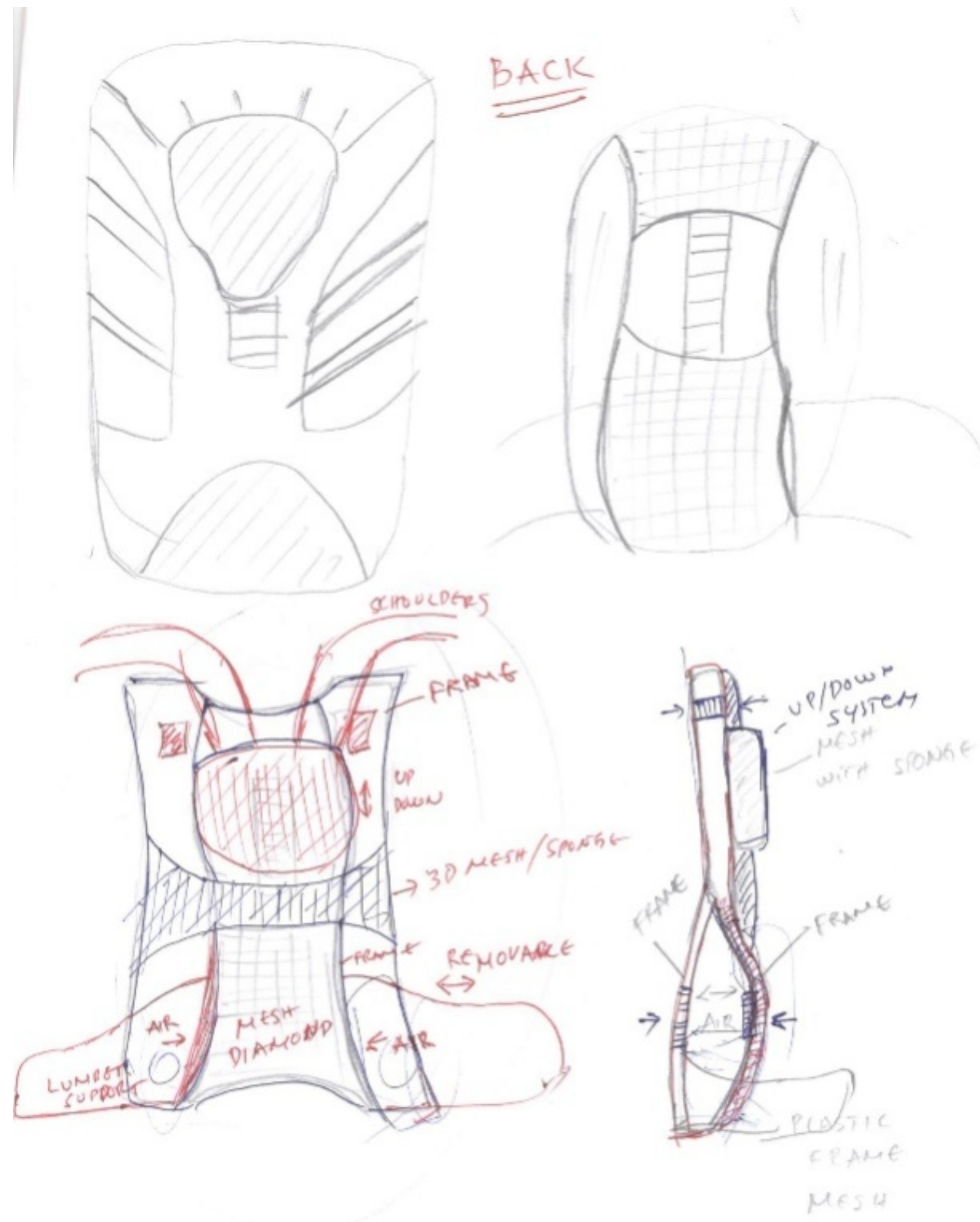

Слика 9.5 Концепт 3 дизајн на задниот дел на рамката (ергономски грб) 


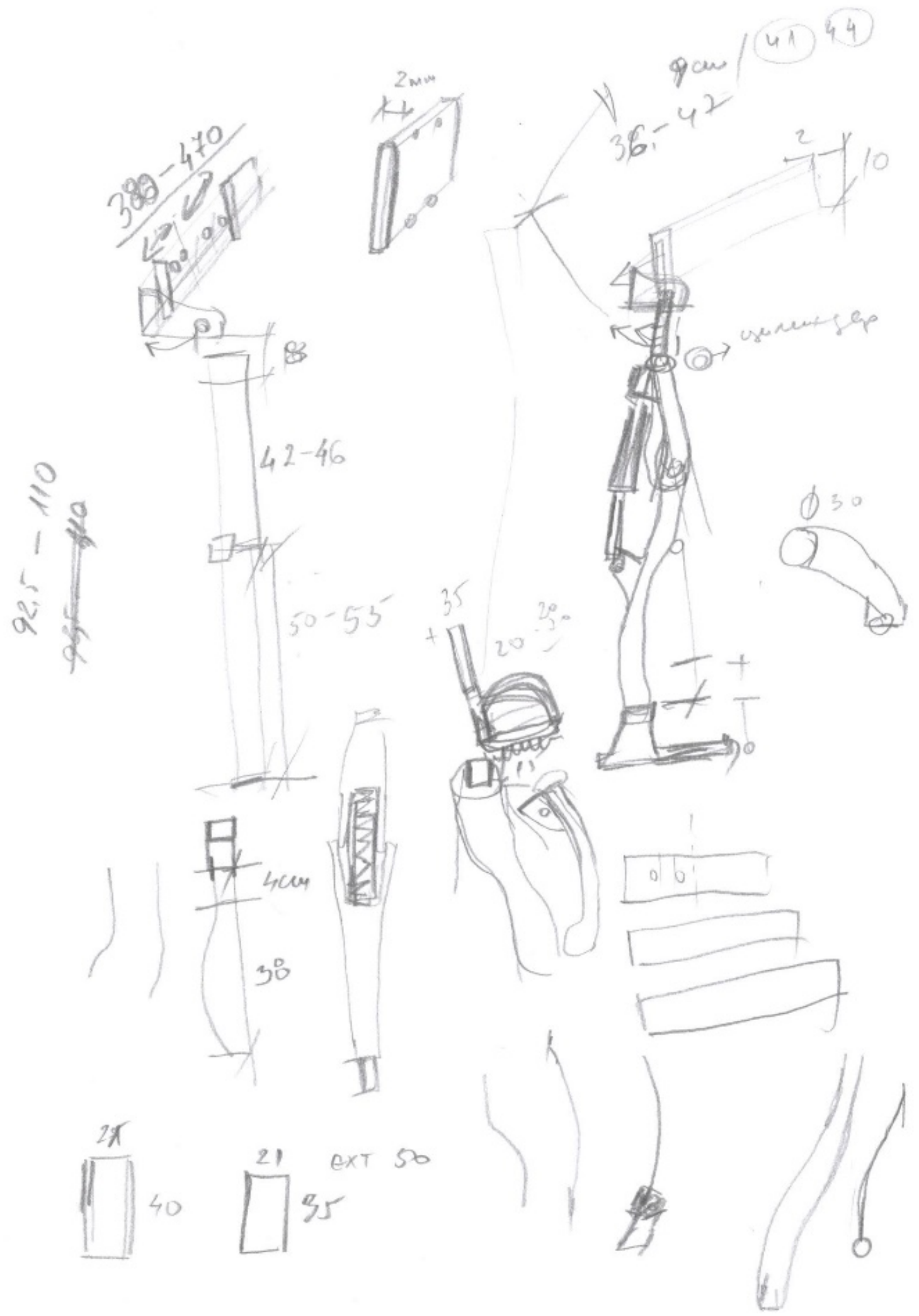

Слика 9.6 Концепт 3 дизајн на егзоскелет компоненти 

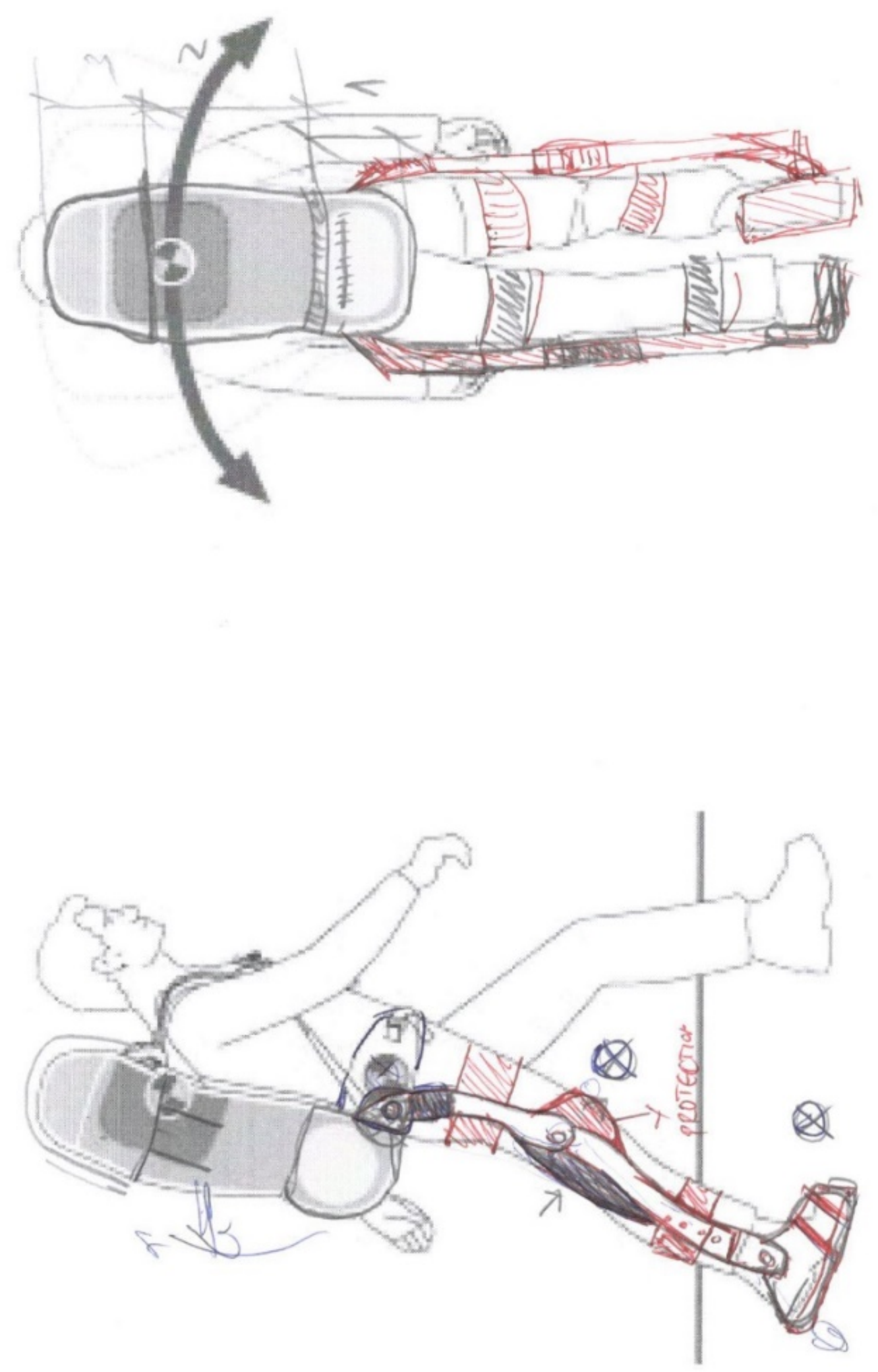

Слика 9.7 Концепт 3 дизајн на егзоскелет (поглед од страна и назад 

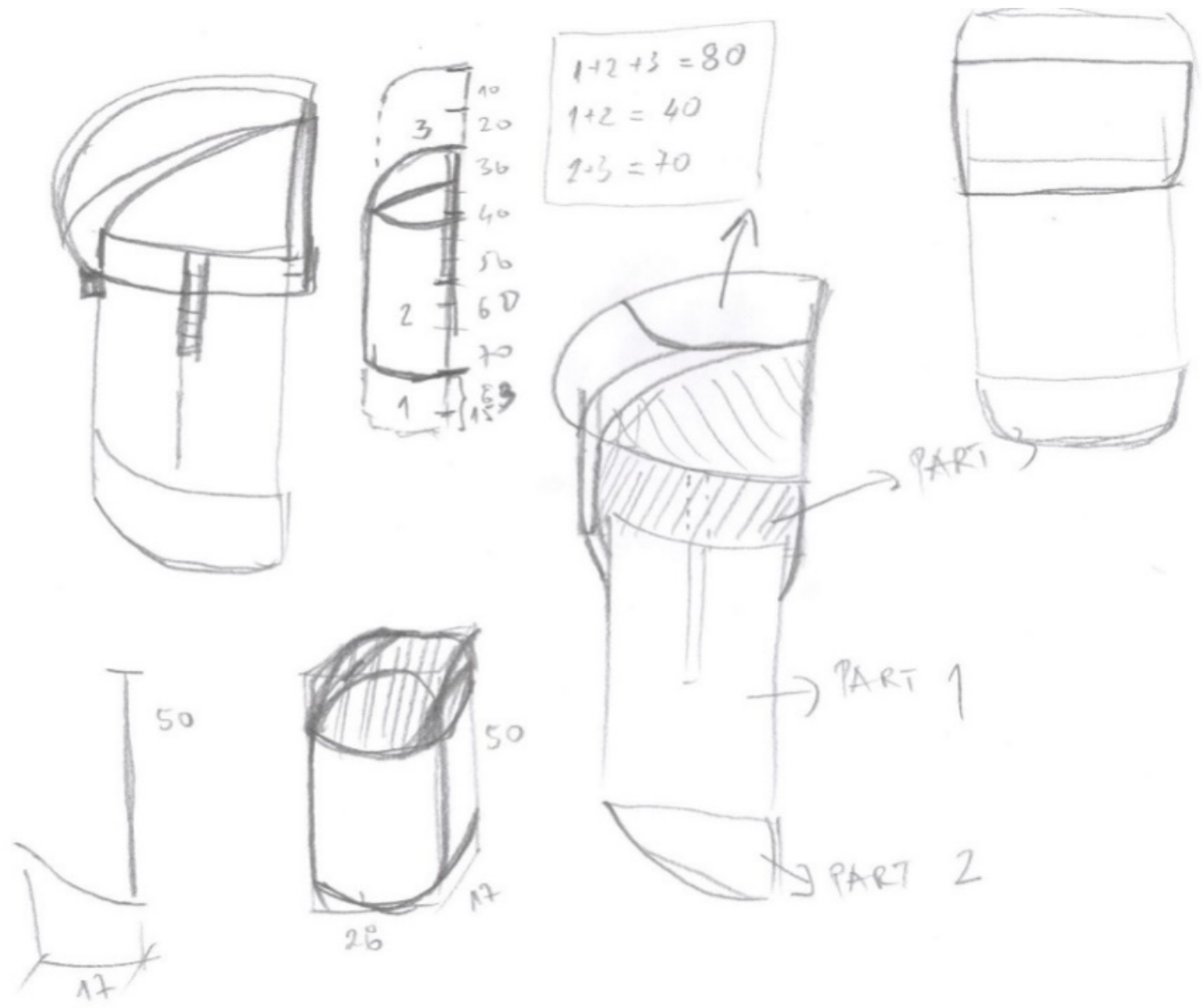

Слика 9.8 Концепт 3 модуларен дизајн на ранец

Од друга страна предвидено е ранецот да биде модуларен, со што би можело да се подесува капацитетот на ранецот според потребите на планинарот. Ранецот може да има 3 големини 40 литри, 55 литри и 75 литри.

На предниот дел на ранецот е планирано да има вградени фрлексибилни сончеви ќелии од типот all-in-one, преку што корсниците би добивале напојување за електронски уреди.

Основниот градбен материјал за ранецот е планирано да бидат полиетеленски плочи кои се обложени со полиамидно платно. Преку процесот на термоформирање се избегнува конвенционалниот дизајн на ранец и се добива минималистички дизајн со геометриски форми. Преку овој начин на изработка се намалува времето за производство на ранецот, се намалува цената.

Мултифункционалноста кај овој ранец се постигнува со опционалното вградување на егзоскелет, преку што се овозможува поголема носивост, поголема подршка и помалку болки и замор при користење. Егзоскелетот има можност за трансформирање преку што се добива конструкција за поставување на шатор. 
Овој концепт ги има следните карактеристики:

1. Ранец со 2 надворешни рамка

2. Надворешната рамка 1 е дел од ергономскиот грб

3. Надворешната рамка 2 е дел од ранецот

4. Ергономскиот грб е компатибилен со други видови на ранци

5. Ергономски подесувања на грбот

6. Мултифункционален ранец

7. Можни капацитети на ранецот: 40л, 55л и 75л

8. Вграден телескопски додаток за шатор во надворешната рамка 2 на ранецот

9. Отстранлив додаток (појасник) за прицврстување на ранецот

10. Можност за прикачување на егзоскелет на надворешната рамка

11. Ергономски подесувања на егзоскелетот

12. Вградени соларни панели на предниот дел од ранецот

13. AIRFLOW систем на грбот

14. Ергономски нараменици

15. Системза намалување на тежината на нарамениците FLOATING

16. Голем број на прегради

17. Минималистички дизајн

18. Уникатен дизајн

19. Материјали од најновата генерација

20. Едноставна изработка

\section{4 Избор на концепт за понатамошна разработка}

Со примена на методот на пајажина слика (46) се гледа зошто е избран концептот 3 за доработка.

Според критериумите кои се клучни при избор на ранец и оценките кои ги добиваат концептите се формира модел на пајажина на кој илустративно е прикажано кој концепт има најдобри оценки. Критериумите кои се клучни за планинарските ранци се: Удобност, ергономија, компактност, мултифункционалност, модуларност, капацитет, материјали и дизајн. 


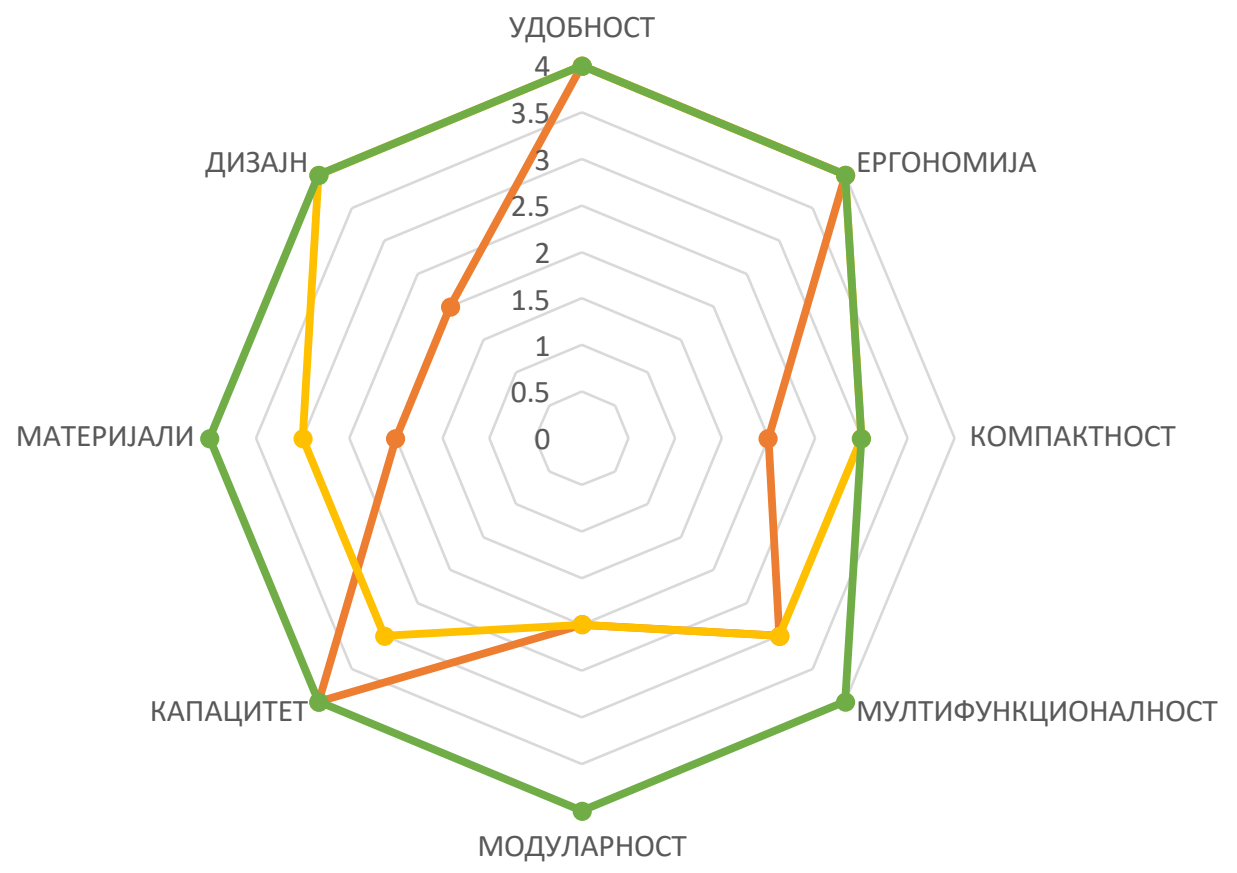

Слика 9.9 Избор на концепт за доработка според методот на пајажина

Избраниот концепт на мултифункционален ранец ги задоволува сите зададени критериуми, но и многу други барања кои се задолжителни при дизајнирање на ваков производ. 


\section{0. ДЕТАЛНА РАЗРАБОТКА НА ИЗБРАНИОТ КОНЦЕПТ}

Избраниот концепт е детално разработен како 3D модел со примена на софртверот SOLIDWORKS.

\section{1 Опис на градбата на ранецот}

Ранецот е дизајниран како склоп од неколку компоненти (модули) презентирани на слика 10.1 и слика 10.2 :

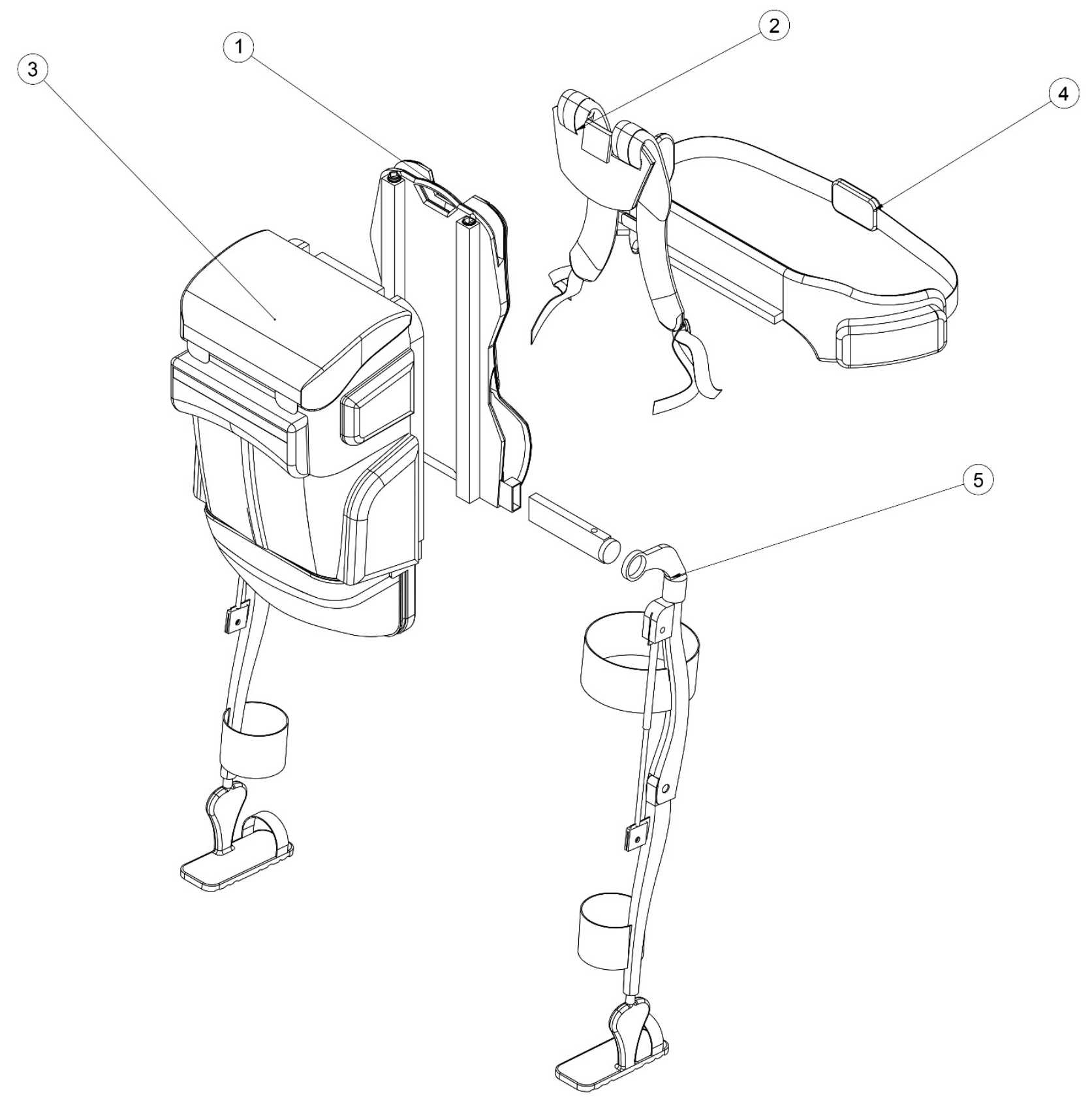

Слика 10.1 Основни делови (модули) на ранецот за планинарење 


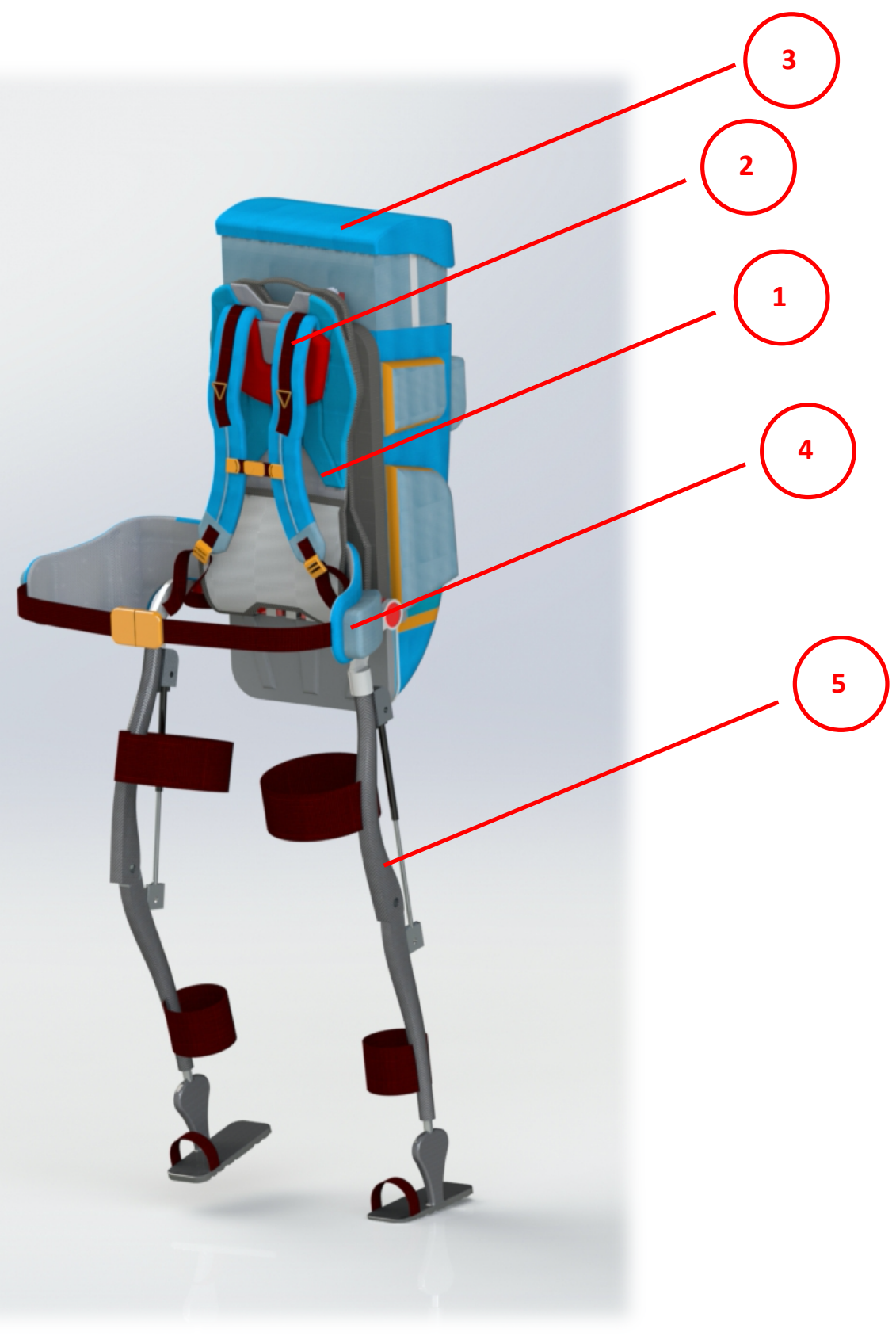

Слика 10.2 Градба на ранецот

- МОДУЛ 1 - Надворешна рамка со ергономски грб

- МОДУЛ 2 - Нараменици

- МОДУЛ 3 - Ранец со надворешна рамка со променлив капацитет

- МОДУЛ 4 - Појасник за поголема удобност и сигурност (LUMBER SUPPORT)

- МОДУЛ 5 - Егзоскелет конструкција која се монтира на ранецот и може да се трансформира како конструкција за шатор 
Според Улрих [13] како што беше погоре споменато, овој концепт има модуларна дизајн архитектура, бидејќи е составен од модули кои се независни едни од други и немаат споени интерфејси. Модулите се индивидуални со посебни инетерфејси и преку нивно поврзување се добива конечната функција на производот.

\section{* Надворешна рамка со ергономски грб}

Надворешната рамка е наменета за цврсто одбивање и оддалечување на ранецот од точката на контакт со човековото тело. На оваа рамка се поставени водилки на кои понатаму може да се прикачуваат различни дизајни на ранци со надворешна рамка.

Надворешната рамка има ергономски дизајн кој ја следи линијата на р'бетот. Обложена е co 3DAIRMESH и дополнителни сунѓери кои ја зголемуваат удобноста. Самиот дизајн на рамката и мрежата која е поставена на долниот дел служат за обезбедување циркулација на воздух и имаат за цел спречување на потење на телото. Овој систем е познат како AIRFLOW и AIRCONTACT систем. На контактниот дел од рамката се поставени ткаени траки на кои се прикачуваат нарамениците и имаат за цел ергономско подесување по висина на нарамениците UP/DOWN SYSTEM.

Во каналите на надворешната рамка се вградени телескопски шипки со должина од $50 \mathrm{~cm}$, кои може да се издолжат до 2м должина со цел правење на конструкција за шатор за едно лице.

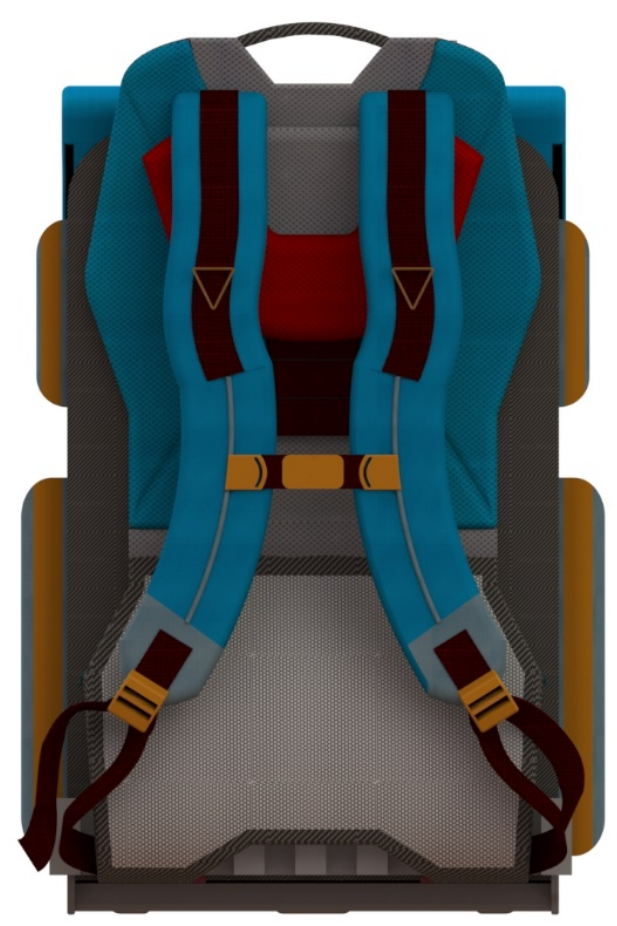

Слика 10.3 Надворешна рамка со ергономски грб

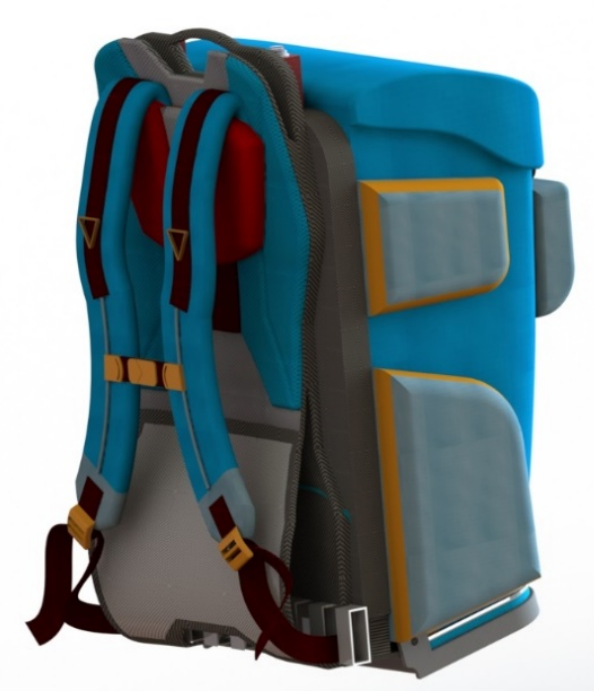

Слика 10.4 Заден дел на ранецот 


\section{* Нараменици}

Нарамениците се посебна компонента од ранецот и се прикачуваат на надворешната рамка на грбот. Со помош на ткаени и чичак траки се прикачуваат на грбот од рамката на соодветната висина според корисникот. Има 5 нивоа на подесување. Формата на нарамениците е ергономска и го следи телото на корисникот. Во внатрешноста се ставаат материјали кои имаат голема моќ на апсорпција и дополнителна удобност. На самите нараменици се наоѓa механизам за прикачување и поврзување на двата нараменика околу торзото на корисникот со што се зголемува удобноста и сигурноста. Овој механизам е прикачен на пластични додатоци SLIDERS кои имаат можност за вертикално подесување по желба на корисникот.

\section{* LUMBER SUPPORT појасник}

Овој појасник спаѓа во дополнителни компоненти, се користи само кога ранецот има голем капацитет и голема тежина. Се монтира на надворешната рамка и служи за дополнително прицврстување на ранецот околу корисникот, со што му нуди поголема удобност и намалување на гравитациските придвижувања на ранецот. Со овој додаток се менува тежиштето на ранецот, а со тоа и оптоварувањата на телото. Пресметано е дека со овој додаток на големина на ранец со над 80 см тежината се намалува за 15\%.

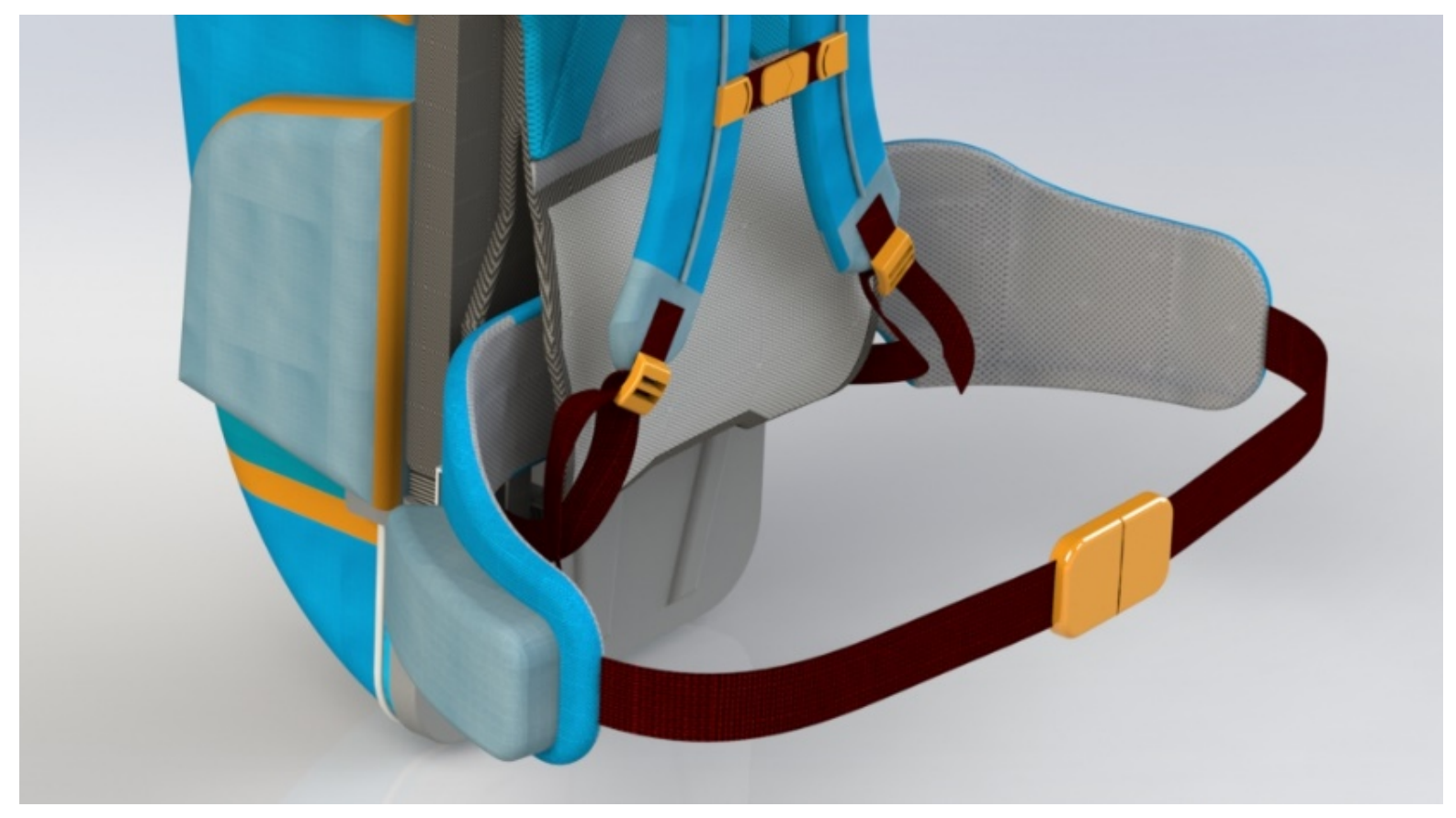

Слика 10.5 Lumber support (појасник) 


\section{* Ранец - пакет}

Ранецот е дизајниран како посебен дел, бидејќи на него се наоѓа надворешната рамка 2 преку која ранецот се поврзува со надворешната рамка 1, а со тоа и со човековото тело. Надворешната рамка 2 (Слика 54) има дизајн со кој се овозможува ранецот да лизга 56см вертикално по рамката2 при нормално движење, со што се редуцираат силите и тежината во нарамениците за $60 \%$. На тој начин се овозможува носење на големи тежини во ранецот, а на човековото тело се чувствува мало оптоварување.

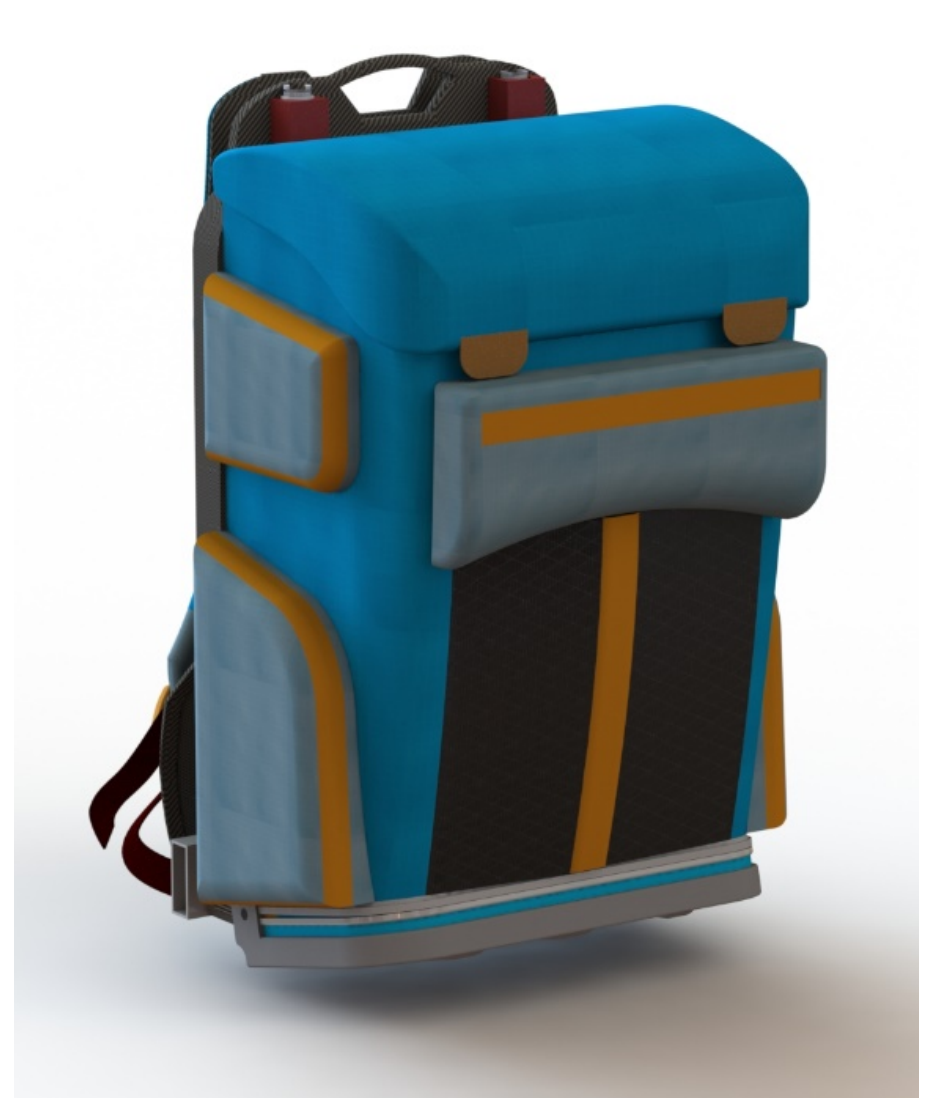

Слика 10.6 Ранец 40 литри

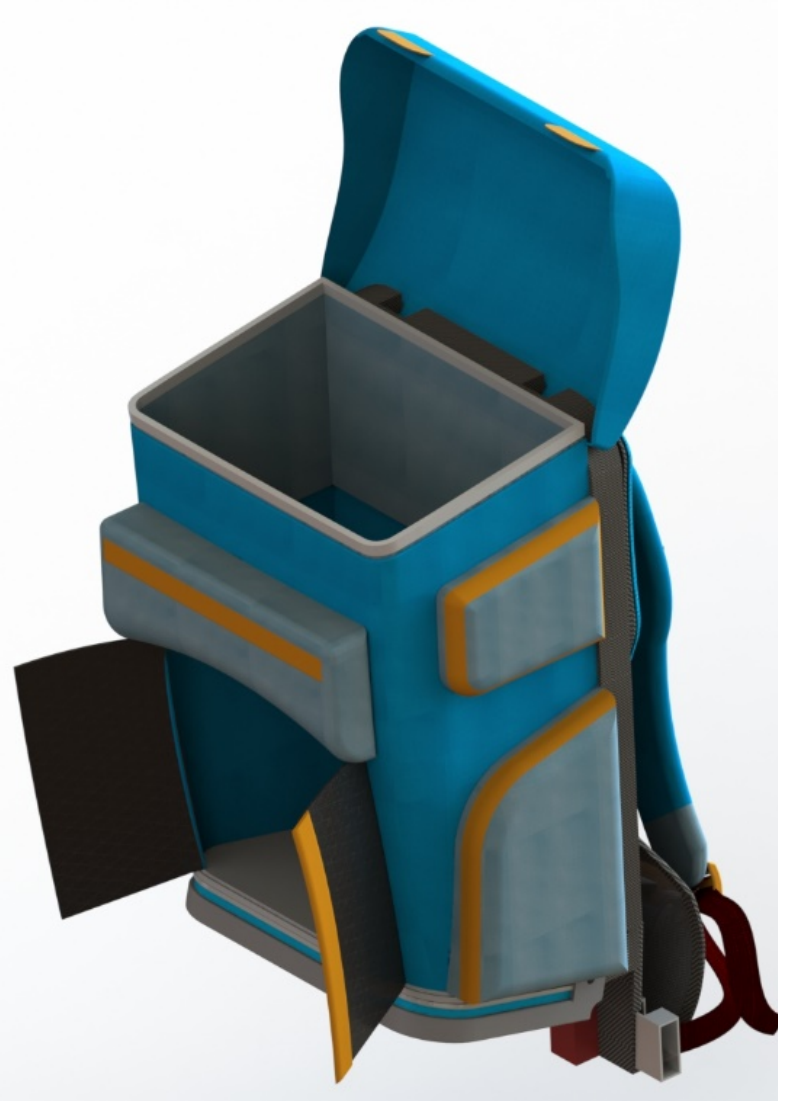

Слика 10.7 Простор за пакување ранец од 40 литри 


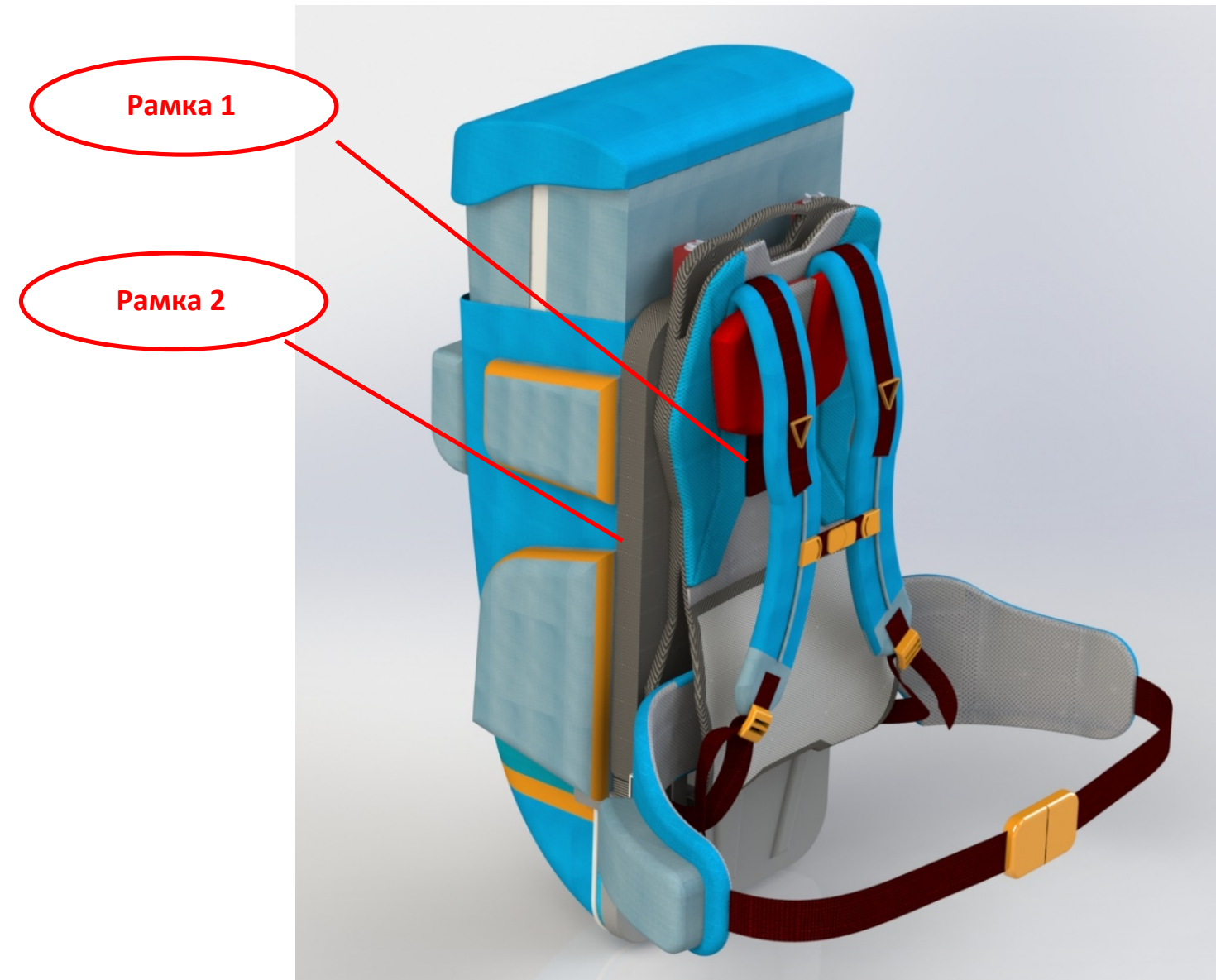

Слика 10.8 Ранец од 75 литри со издолжување на внатрешен дел и отворање на дното
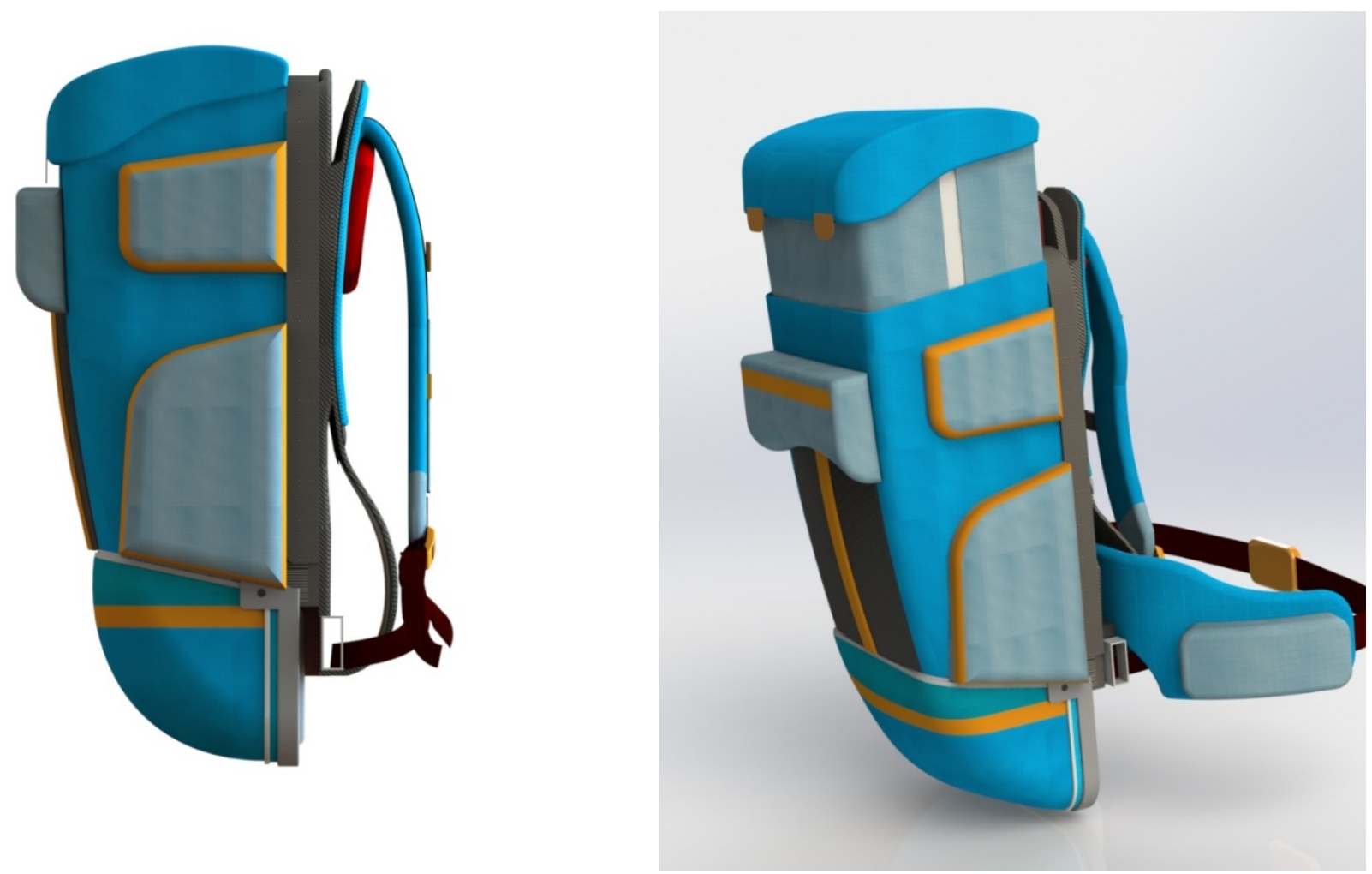

Слика 10.10 Ранец од 75 литри 


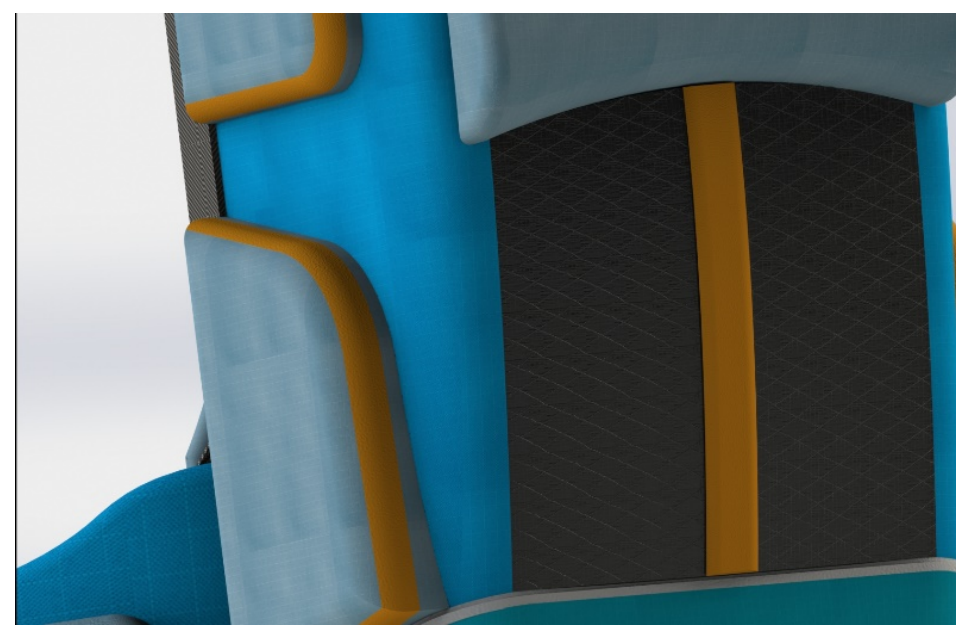

Слики 10.11 Сончеви ќелии

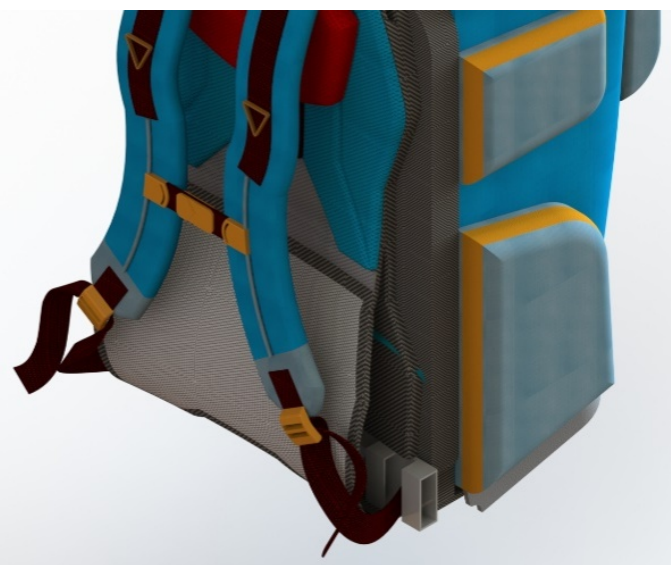

Слика 10.12 Ергономски грб

Ранецот има модуларен дизајн, така што може да се користи за повеќе намени. Сe состои од 3 дела. Првиот дел или основата е главниот дел на ранецот и има капацитет од 40 л (Слика 52). На него се наоѓаат сончевите панели и батериите преку кои се добива енергија за полнење на електронски уреди или ЛЕД осветлување.

Долниот дел на ранецот се продолжува преку специјален патент, со што се отвора и се зголемува капацитетот на ранецот за дополнителни 15л. Дното на ранецот се изработува од CROSS LINKED POLYETHILENE плоча со цел добивање на цврстина и заштита од кршење.

Ранецот на горниот дел има внатрешен дел со механизам за вертикално поместување. Преку овој механизам ранецот се издолжува нагоре и се зголемува капацитетот на ранецот за дополнителни 20л. Со ова вкупниот капацитет на ранецот е 75л.(Слика 10.10)

\section{* ЕГЗОСКЕЛЕТ дополнителна подршка}

Егзоскелетот е веќе познат бионички производ кој скоро е пуштен во комерцијална употреба и служи за помош на луѓе на кои им треба подобрување на фризичките способности, т.е за помош при движење. 


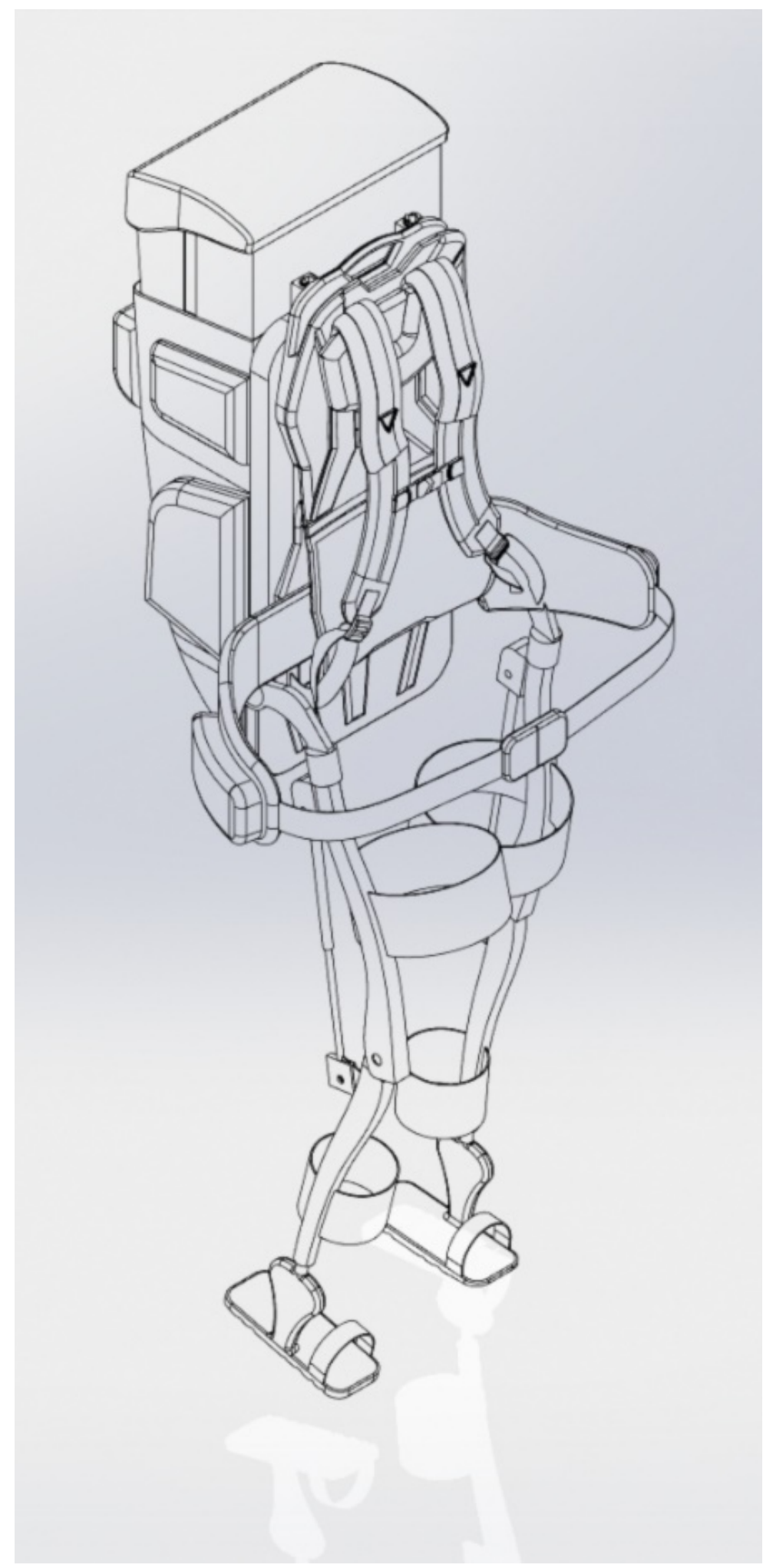

Дизајнот на егзоскелетот кој е составен дел од ранецот е бионички и многу едноставен механизам кој има за цел пренесување на целата тежина на ранецот од рамената во колковите и директно на чевлите. Друга намена е подршка на телото и давање на дополнителна цврстина на телото.

Механизмот има неколку точки на подесување со цел прилагодување на секој корисник. Хоризонтално поместување на горниот дел и 2 вертикални поместувања кај нозете.

Се прицврстува за нозете на 2 позиции и една позиција за прицврстување на чевлите. $\mathrm{Ce}$ монтира од надворешната страна на нозете. Ги следи сите функции на нозете, движење, клекнување, трчање.

Егзоскелетот е едноставен за монтирање и се монтира на надворешната рамка со грбот со навртување на осовината.

Слика 10.13 Конструкција на ранец со егзоскелет 


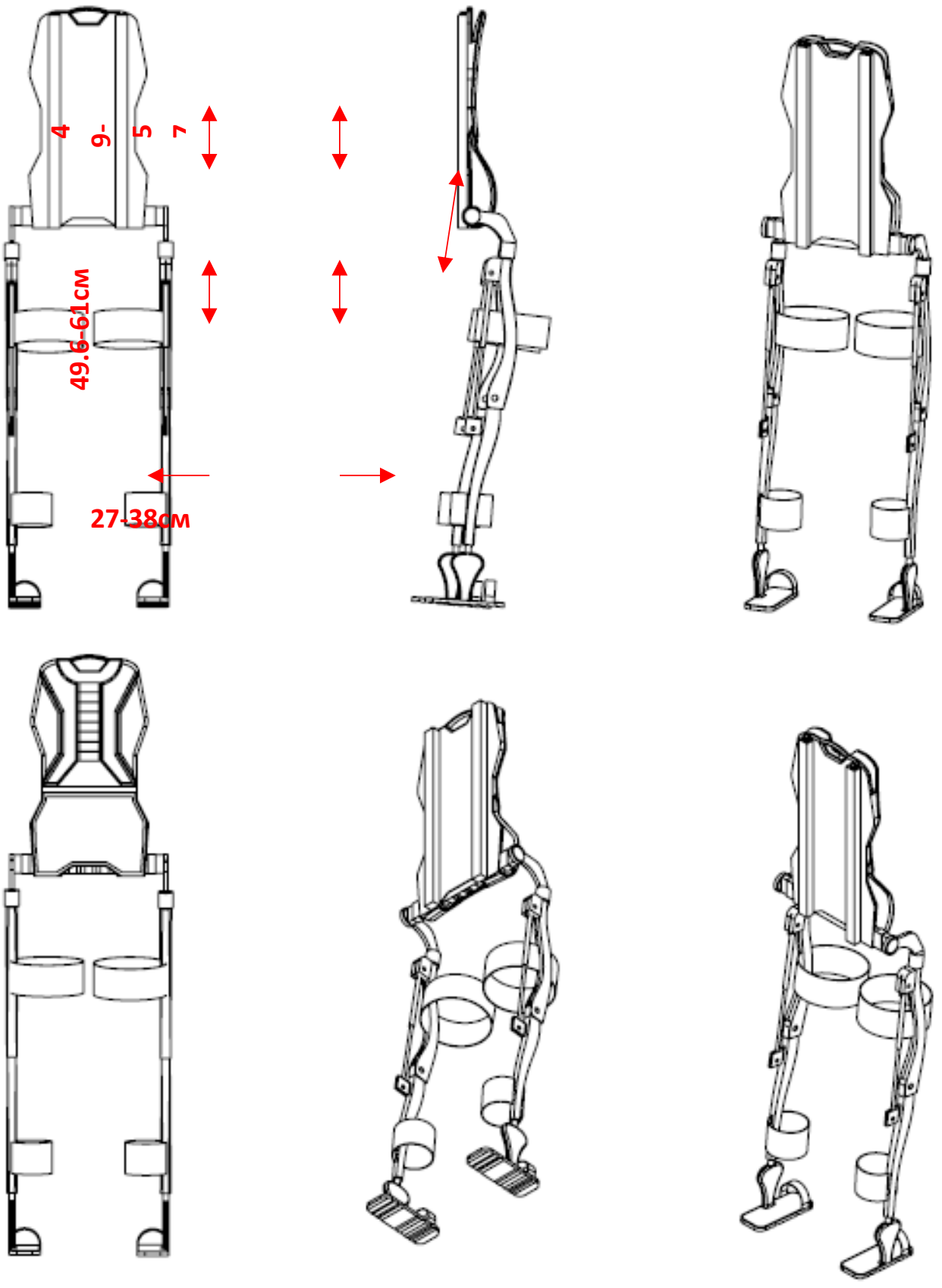

Слика 10.14 Ергономски подесувања на егзоскелет 


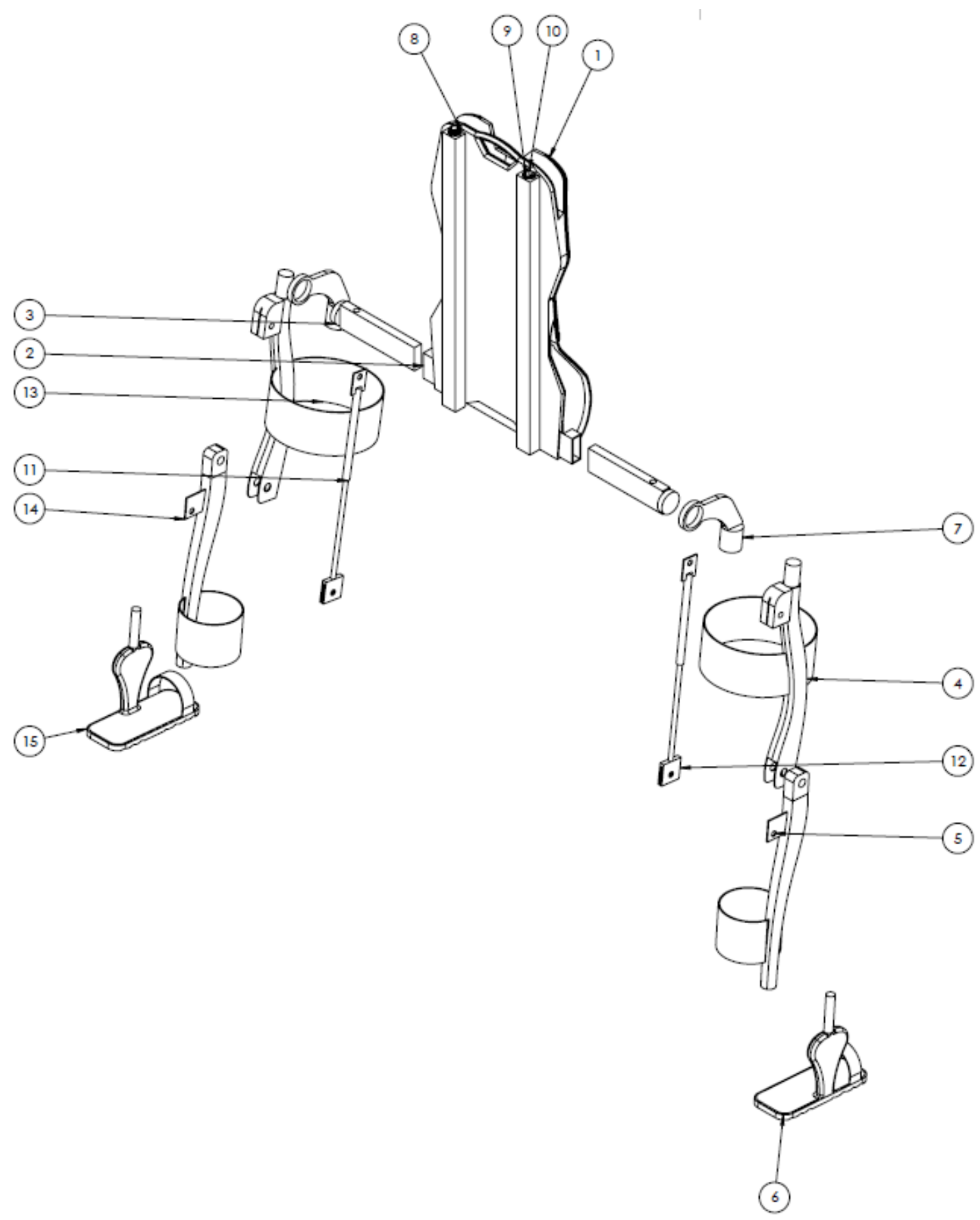

Слика 10.15 Склопен цртеж за егзоскелет

На самите држачи на егзоскелетот со едноставна трансформација се добива можност егзоскелетот да може да се користи како конструкција за шатор. Така егзоскелетот добива дополнителна функција. Кога не се користи, може да се склопи и да се прицврсти на страните од ранецот (Слика 10.16). 


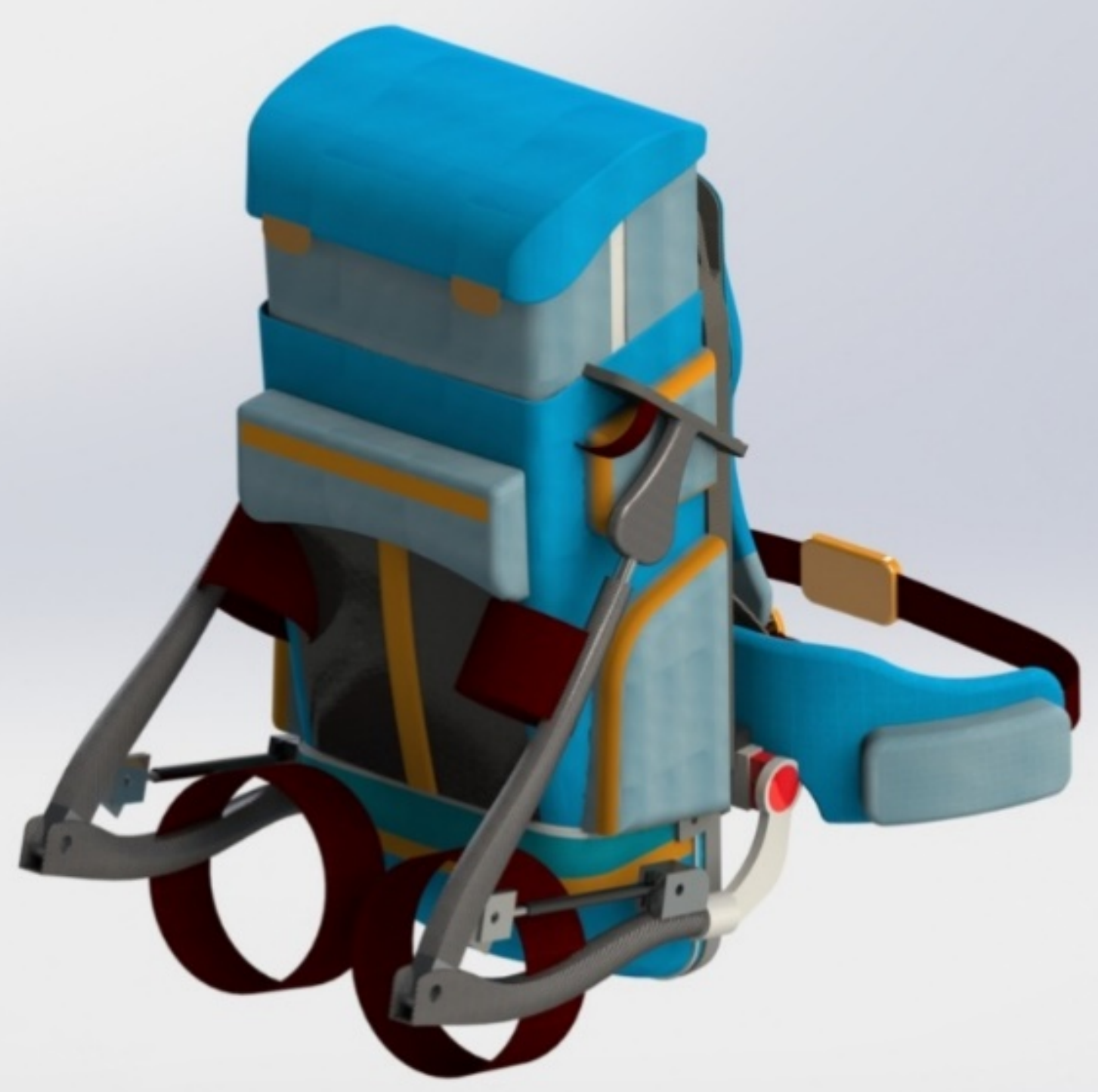

Слика 10.16 Егзоскелет во собрана положба 
* Шатор

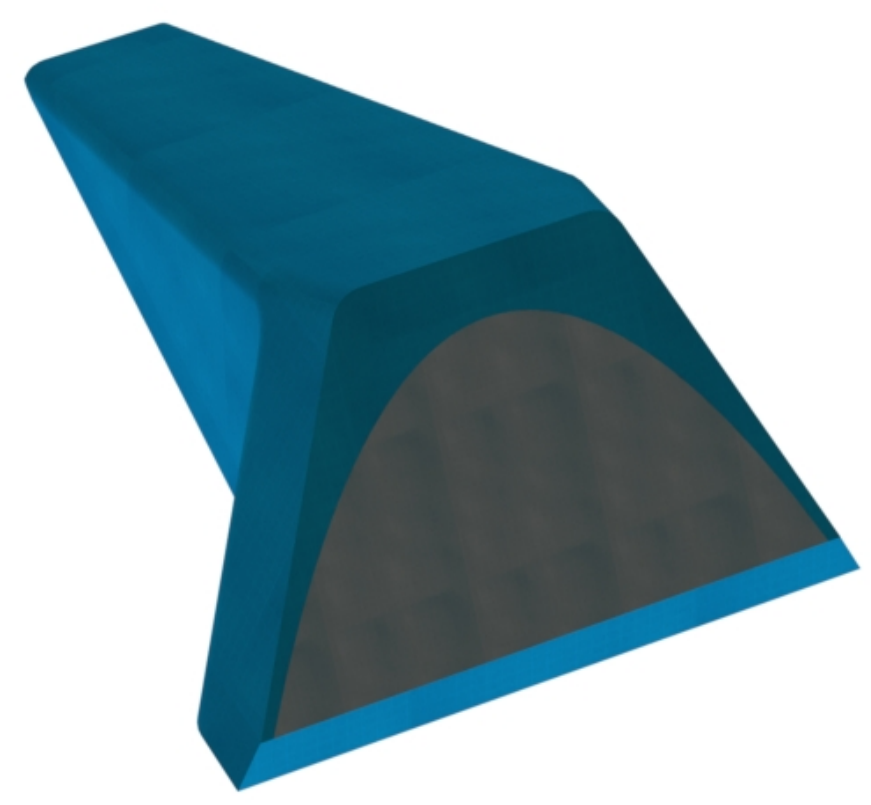

Слика 10.17 Шатор за едно лице

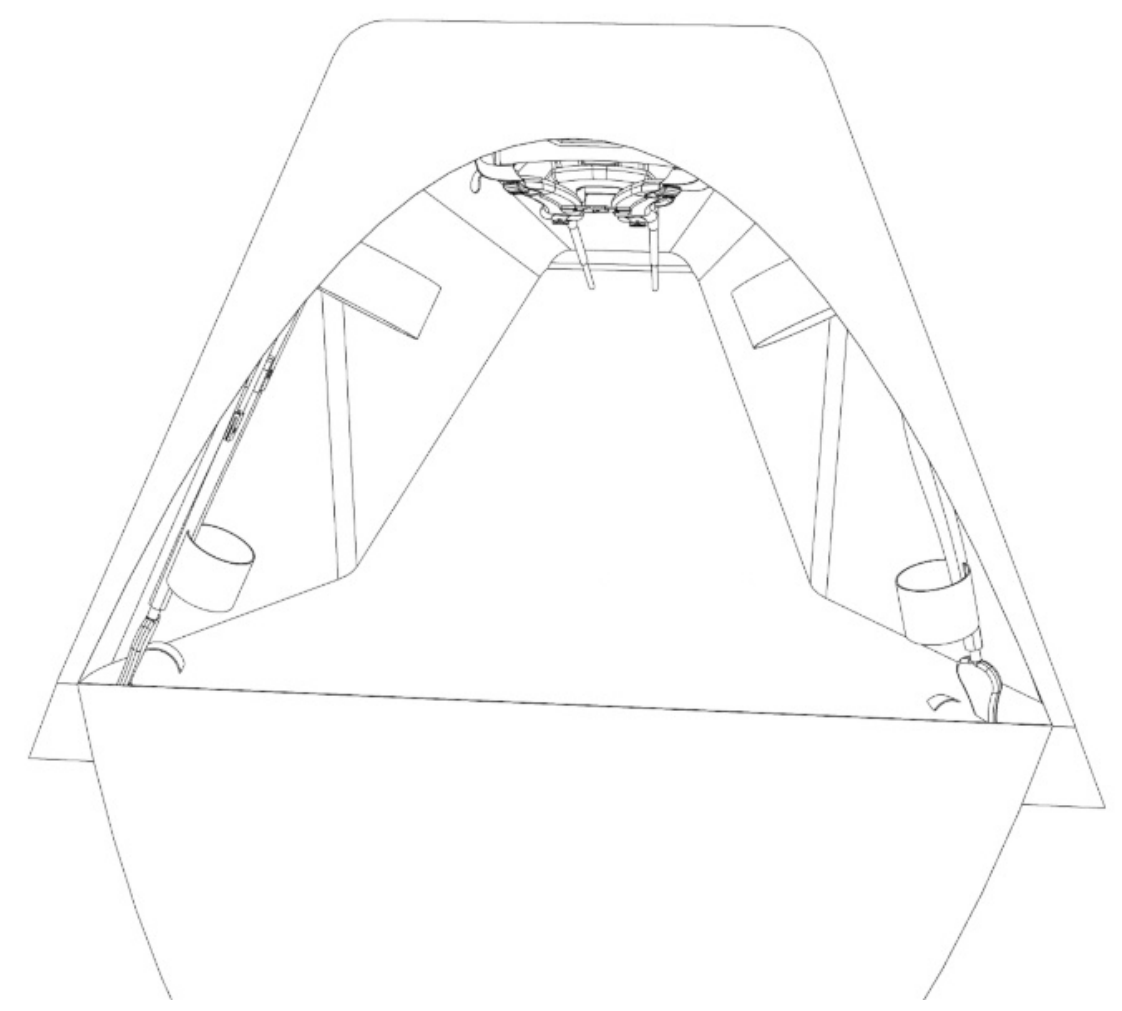

Слика 10.18 Шатор за едно лице 
Шаторот за едно лице е вграден во долниот дел од ранецот, додатокот од 15л. Со трансфрормирање на телескопските профили вградени во надворешната рамка и трансформирањето на егзоскелетот се добива целата конструкција за шаторот. Со вметнување на конструкцијата во шаторското платно се добива шатор за едно лице.

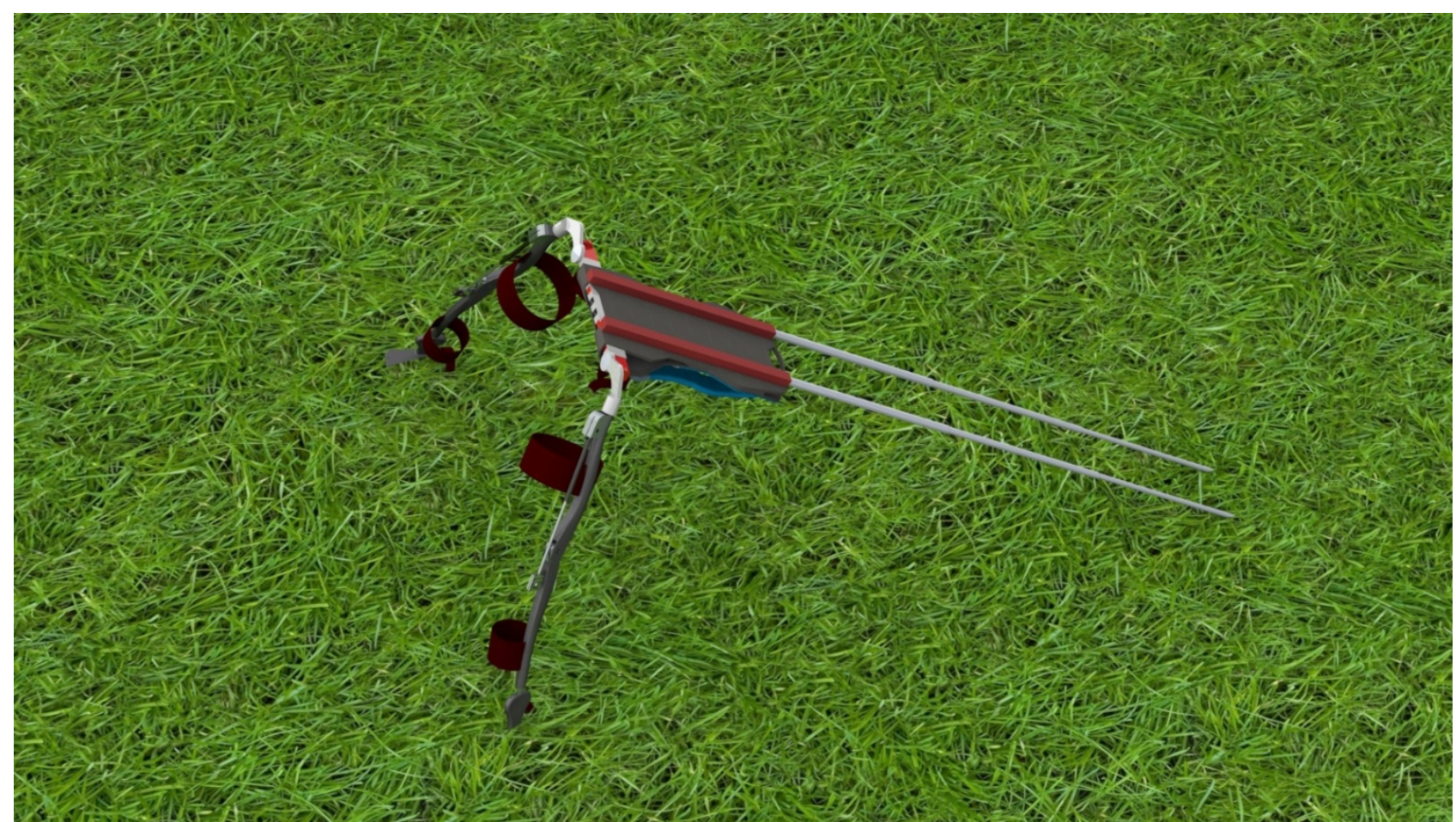

Слика 10.19 Егзоскелет конструкција за шатор

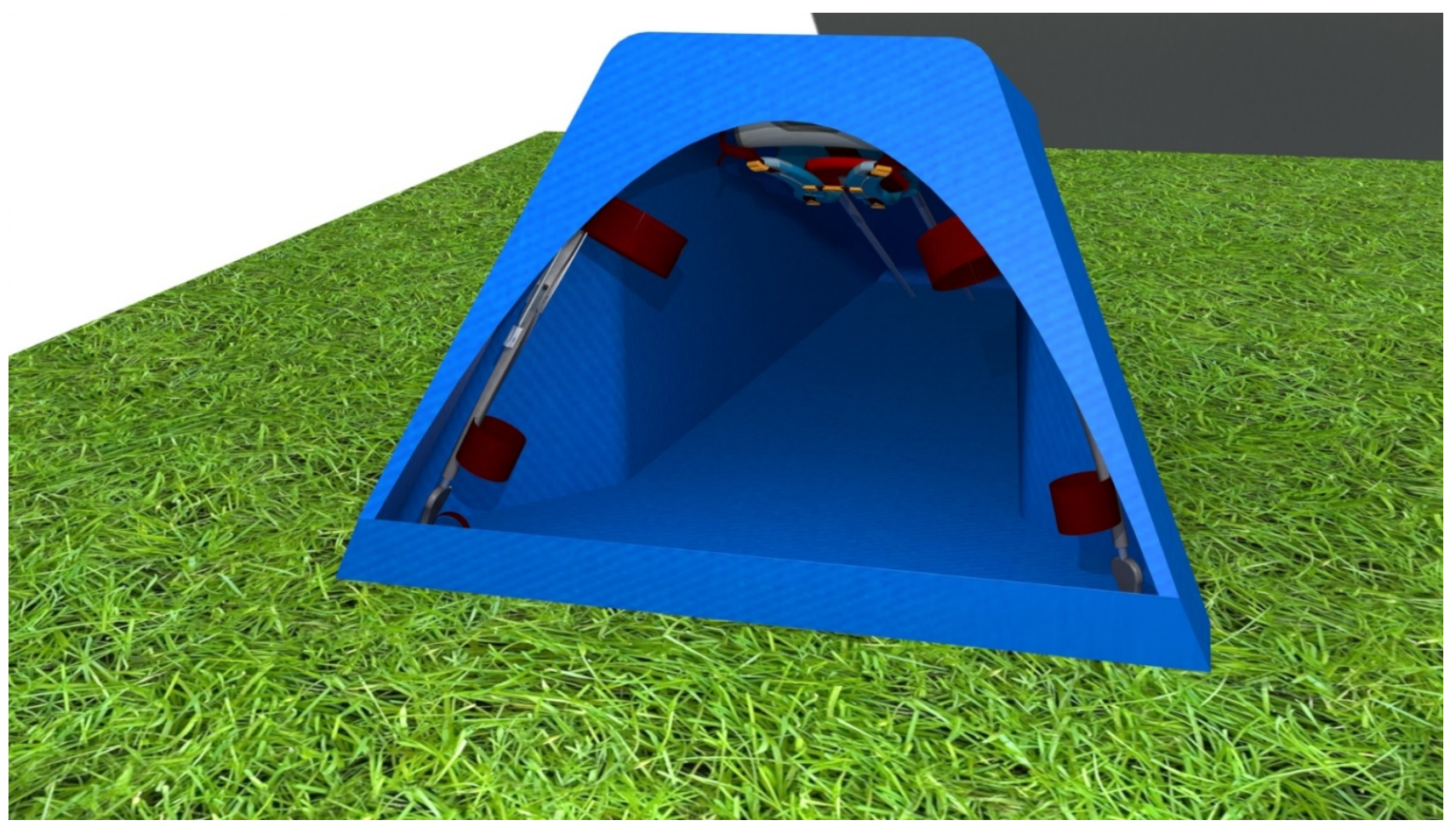

Слика 1-.20 Егзоскелет конструкција за шатор 


\section{2 Антропометриски анализи применети во дизајнот}

Во процесот на дизајнирање беа неопходни потемелни антропометриски анализи со цел да се обезбеди прилагодување за корисници со различни фризички карактеристики. Овој производ не може да се прави во повеќе големини и затоа треба да има можност секој негов дел да се прилагоди според корисникот. Затоа, како што е споменато погоре, се врадени повеќе компоненти со можност за подесувања. Запазени се стандардни димензии на подесување да може да одговараат на 95\% од корисниците.

Главни антропометриски димензии кои се земени се:

- Висината на телото (1)

- Ширината на телото кај рамената (11)

- Ширината на телото кај колковите (5)

- Должината на нозете од колената до стапалата (12)

- Должина на нозете од колковите до колената (8)

- Висина на рамената (3)

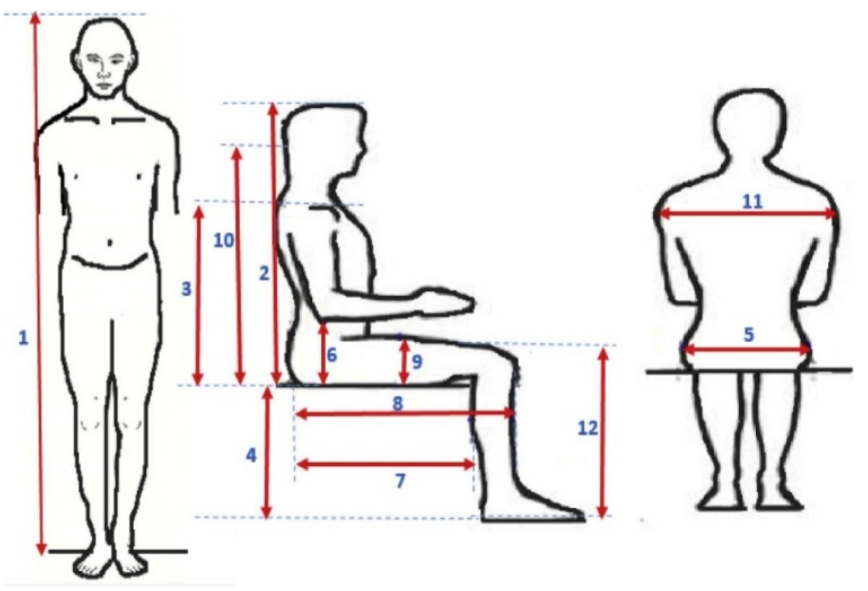

Слика 10.21 Антропометриски мерки

\begin{tabular}{|c|c|c|c|c|}
\hline Број & Опис & $\begin{array}{c}\text { 95-ти Перцентил } \\
\text { на маж }\end{array}$ & $\begin{array}{c}\text { 50-ти перцентил } \\
\text { на маж }\end{array}$ & $\begin{array}{c}\text { 5-ти перцентил на } \\
\text { жена }\end{array}$ \\
\hline 1 & Висина на телото & $181 \mathrm{~cm}$ & $171 \mathrm{~cm}$ & $160 \mathrm{~cm}$ \\
\hline 11 & Ширина на рамената & $46,2 \mathrm{~cm}$ & $42 \mathrm{~cm}$ & $38 \mathrm{~cm}$ \\
\hline 5 & Ширина на колковите & $38 \mathrm{~cm}$ & $32 \mathrm{~cm}$ & $49 \mathrm{~cm}$ \\
\hline 12 & $\begin{array}{c}\text { Должина на нозете од колената } \\
\text { до стапалата }\end{array}$ & $57 \mathrm{~cm}$ & $53 \mathrm{~cm}$ & $49,6 \mathrm{~cm}$ \\
\hline 8 & $\begin{array}{c}\text { Должина на нозете од } \\
\text { колковите до колената }\end{array}$ & $61 \mathrm{~cm}$ & $56 \mathrm{~cm}$ & $52 \mathrm{~cm}$ \\
\hline 3 & Висина на рамената & $62 \mathrm{~cm}$ & $57 \mathrm{~cm}$ & \\
\hline
\end{tabular}

Табела 5 : Антропометриски мерки за 95-ти перцентил, 50-ти перцентил и 5-ти перцентил 


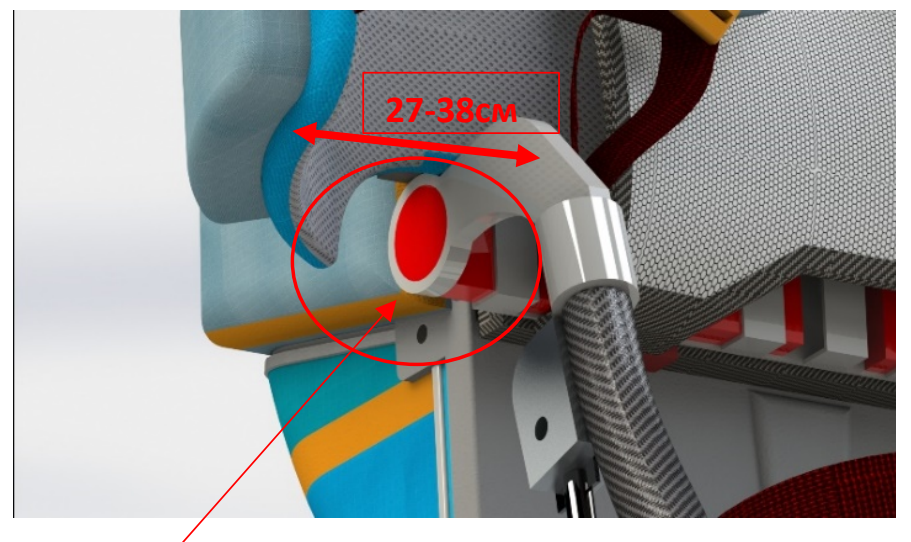

Слика 10.22 Подесување на егзоскелетот по ширина за соодветен перцентил

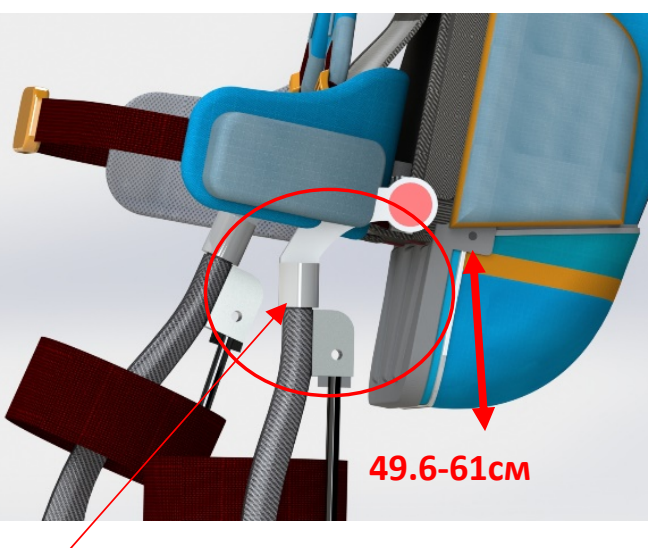

Слика 10.23 Подесување на егзоскелетот по висина за соодветен перцентил

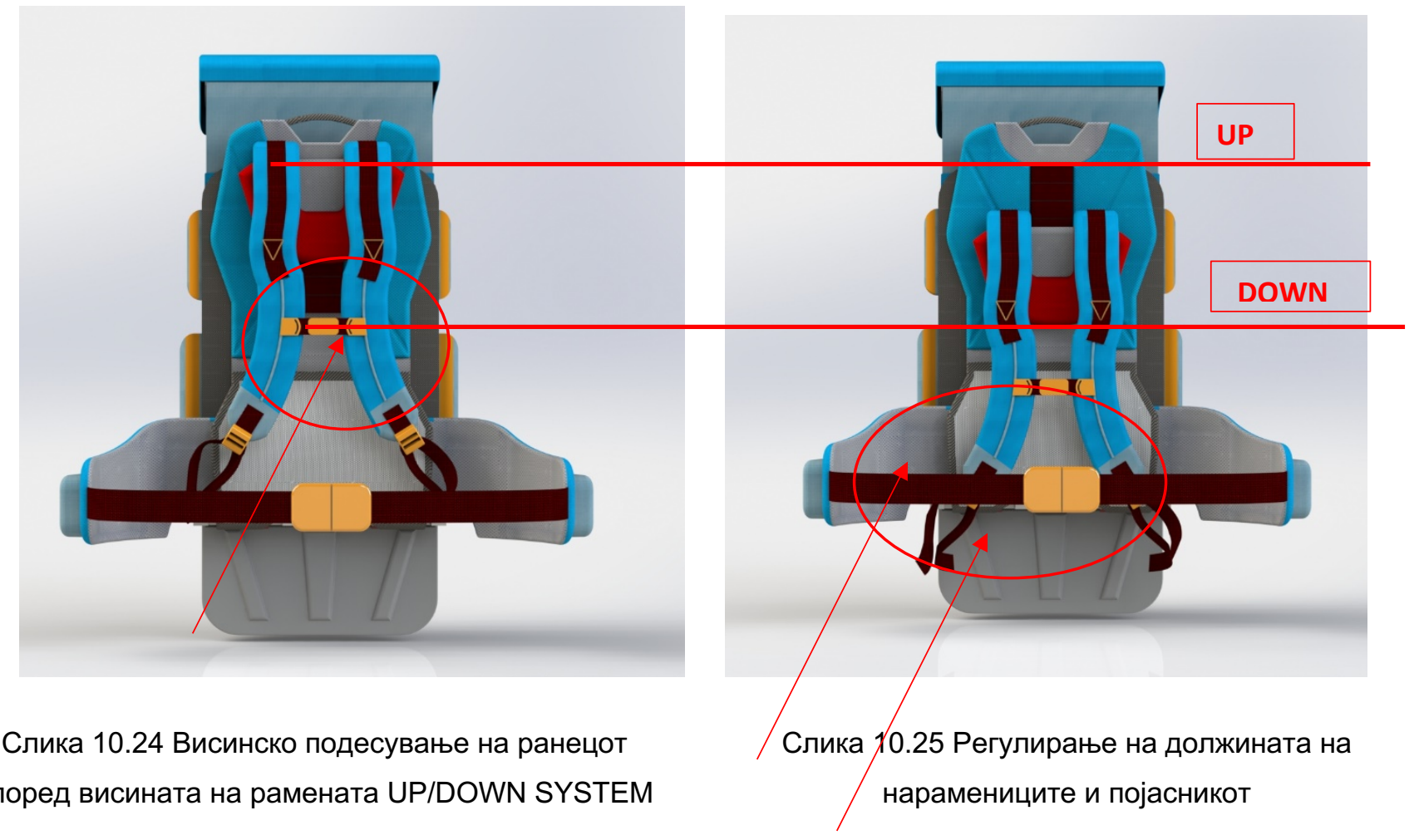

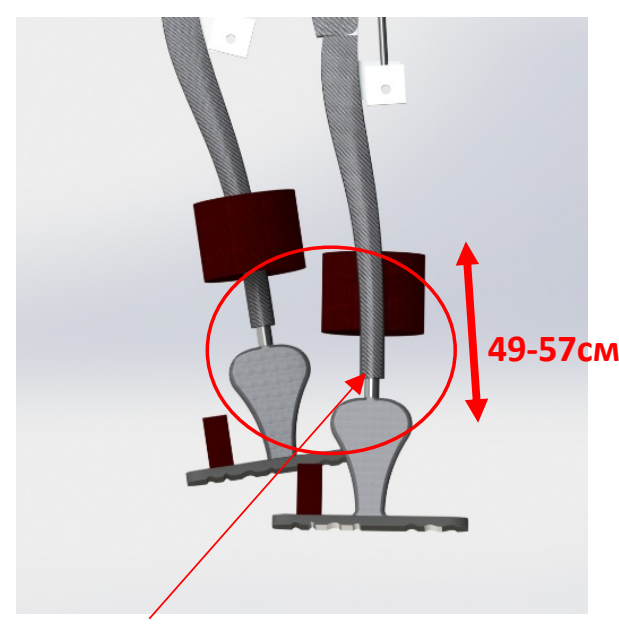

Слика 10.26 Подесување на егзоскелетот за соодветна должина на нозете

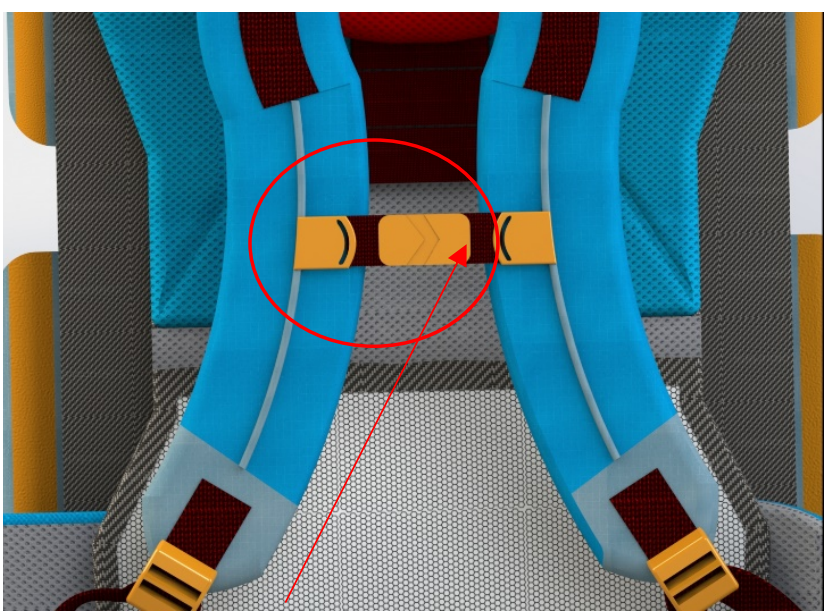

Слика 10.27 Подесување на стегачот на торзото по висина и ширина 


\section{3 Избор на материјали за изработка}

Презентираниот ранец е дизајниран со строги геометриски линии. Се предвидува да биде изработен од полиетиленска плоча со дебелина од 2мм, со што целата конструкција и изведба на ранецот би била крута. Од повеќе аспекти се планира да се искористи токму овој материјал, поради тоа што е многу лесен, водоотпорен, апсорбира удари и е рециклабилен. Со тоа се добива висока заштита на опремата и можност за модуларност.

Постоечките ранци за планинарење сеуште го задржуваат начинот на изработка каде $90 \%$ од изработката е со шиење. Поради тоа, цената на чинење на овие производи е доста висока. Автоматизацијата на процесот на производство на ранци со шиење на ниско ниво. Ранецот како производ има премногу делови и е многу комплициран за изработка. Ова е уште една причина заради која како конструкциски материјал е избрана полиетеленска плоча.

Процесот на производство на ваков тип на дизајн е со примена на термоформирање, поради што се неопходни соодветни калапи за секој дел посебно зарадинивно обликување. Останатиот дел од обработката е шиење. Овде шиењето опфаќа околу 30\% од операциите, што значи вклучување на помалку луѓе во производниот процес, а со тоа и пониска цена на чинење на производот.

Дизајнот за секоја компонента е независен и може да се произведуваат во ралични фабрики и на различни локации. Ова е уште една придобивка со што се намалува цената на чинење и избегнување на класичното производство. 


\section{1. ЗАКЛУЧОК}

Во овој магистерски труд е презентирано истражување посветено на неколку важни аспекти во дизајнот на производи - мултифункционалност и оптимизација на просторот. Голем број причини, особено еколошките, бараат редукција на големината на производите и максимално искористување на просторот за сместување на нивните механички, електронски и други уреди кои ја обезбедуваат нивната функција, или пак за сместување на други предмети за кои се наменети. Мултифункционалноста кај производите оди во прилог на ова барање бидејќи обезбедува искористување на постоечките ресурси за реализација на повеќе функции, со што повторно се остварува заштеда на простор.

Од бионичкото истражување спроведено во рамките на овој магистерски труд беа извлечени неколку важни заклучоци во врска со формите и структурите кои обезбедуваат најоптимално искористување на просторот. Испитувањето на биолошките фрорми и структури во природата покажа дека геометриските форми базирани на правилни многуаголници обезбедуваат подобра оптимизација на просторот отколку органските форми. Од друга страна, примената на модуларниот пристап обезбедува подобра оптимизација на просторот. Структури од модули подредени ортогонално обезбедуваат максимално искористување на просторот, исто како и структурите од модули кои формираат спирали подредени со примена на принципот на златен агол. Еден производ со повеќе функции ќе обезбеди поголем корисен простор и намалување на димензиите на производот.

Заклучоците од извршените истражувања беа применети во креирање концепт дизајн на мултифункционален ранец за планинарење, кој може да се приспособи во повеќе големини наменети за еднодневни, викенд или долги прошетки, а од друга страна во него се вградени механизми за намалување на заморот и оптеретувањето на мускулите.

Заради потемелен пристап во дизајнот во овој труд беа извршени истражувања во повеќе области релевантни на зададениот проблем. Беа проучени најсовремени иновативни решенија во областа на опремата која се користи за планинарење и главните проблеми со кои се соочуваат планинарите. Исто така, беа проучени порелевантни трудови во врска со ергономијата на носење ранци.

Точните барања и дефинирањето на главните потреби за дизајн на ваков производ беа препознаени дополнително и преку анкетирање на потрошувачите и следење на интернет форуми. Врз основа на сите извлечени заклучоци и дефинирани барања беа 
креирани три концепт - решенија. Најсоодветниот концепт кој нуди решение на сите поставени барања беше одбран преку процесот на еволуација. Ранецот за планинарење кој беше избран како конечен концепт треба да помогне во намалувањето на болките во рамената и р'бетот кои се јавуваат како последица од носењето на ранци и товари со големи димензии. Исто така, треба да им помогне на луѓето со ограничена фризичка мобилност да може повторно да се осмелат да тргнат на пешачење низ природата на подолги релации.

Во овој труд, извлечените заклучоци во вид на хипотези во врска со начинот на кој може да се обезбеди мултифункционалноста и оптимизацијата на просторот кај производите беа докажани преку евалуацијата на дизајнираниот ранец за планинарење. Токму поради тоа, сите тие може да бидат пример за останатите дизајнери за примена во дизајнот на други производи кај кои e неопходна мултифункционалноста и оптимизацијата на просторот.

Од друга страна, ова истражување може да биде пример за тоа колку е важно процесот на дизајнирање да започне со темелни истражувања во врска со сите аспекти релевантни на зададениот проблем и примена на сите расположиви технолошки и научни достигнувања, со цел да се обезбеди најдобар резултат. 


\section{Референци:}

[1] Yong Kim1 and Byung Man (2002) INTERNATIONAL JOURNAL FOR NUMERICAL METHODS IN ENGINEERINGInt. J. Numer. Meth. Engng 2002; Design space optimization using a numerical designcontinuation methodll

[2] Schmit LA. (1960) Structural design by systematic synthesis.Proceedings of the 2nd ASCE Conference; Electronic Computation, Pittsburgh; 105-122.

[3] Kicher TP.(1968) Structural synthesis of integrally stiJened cylinders. Journal of Spacecraft Rockets; 5:62- 67.

[4] Gettatly RA, Gallagher RH.(1966) A procedure for automated minimum weight structural design, Part I—theoretical basis, Part II—applications. Aerospace Quarterly Part I; 17:216-230, 332-342.

[5] Francavilla A, Ramakrishnan CV, Zienkiewicz OC. (1975) Optimization of shape to minimize stress concentration. Journal of Strain Analysis ; 10(2):63-70.

[6] Cea J. (1981) Numerical methods in shape optimal design. In Optimization of Distributed Parameter Structures, vol. II. SijthoJ \& Noordhof: Netherlands,; 1049-1087.

[7] Zolesio JP.(1981), The material derivative (or speed) method for shape optimization. In Optimization of Distributed Parameter Structures, vol II. SijthoJ \& Noordhof: Netherlands; 1089_ 1151.

[8] Rousselet B. ,(1981), Implementation of some methods of shape design. In Optimization of Distributed Parameter Structures, vol. II. SijthoJ \& Noordhof: Netherlands, [9] Haug EJ, Choi KK, Komkov V. (1986), Design Sensitivity Analysis of Structural Systems. Academic press: New York.

[10] Maute K, Ramm E.(1995), Adaptive topology optimization. Structural Optimization; 10:100 -112 .

[11] Alan R. Parkinson Richard J. Balling John D. Hedengren,(2013), Optimization Methods for Engineering Design Applications and Theory

[12] Chryssolouris, G., 2006, Manufacturing Systems: Theory and Practice 2nd edition, Springer, New York

[13] Ulrich, K., 1995, The role of product architecture in the manufacturing firm, Research Policy, 24: 419 - 440

[14] Holtta-Otto, K. and de Weck, O., 2007, Degree of Modularity in Engineering Systems and Products with Technical and Business Constraints, Concurrent Engineering, 15(2): 113- 126 [15] Ramani, K., Cunningham, R., Devanathan, S., Subramaniam, J. and H., Patwardhan, 2004, Technology Review of Mass Customization, International Conference on Economic, Technical 
and Organisational aspects of Product Configuration Systems, Copenhagen, Denmark, June 2004

[16] Suh, NP, 2001, Axiomatic Design, Advances andApplications, Oxford University Press, New York

[17] Ericsson, A. and Erixon, G., 1999, Controlling Design Variants, Society of Manufacturing Engineers, Dearborn, Michigan

[18] Holtta, K. and Salonen, M., 2003, Comparing three modularity methods, In Proc of ASME Design Engineering Technical Conferences, Chicago, IL. September 2003

[19]. AUTEX 2009 World Textile Conference 26-28 May, 2009 Izmir, Turkey 862 DESIGNING MULTIFUNCTIONAL TEXTILE FASHION PRODUCTSJ. Cunha, A. C. Broega [20]. Fourt, L., Hollies, N. R. S.,(1970), Clothing: Comfort and Function, Marcel Dekker, New York, ISBN 0-8247-1214-5.

[21] Slater, K.(1986), The Assessment of Comfort, J. Textile Inst., No.77, 157-171.

[22]Coelho, D. A., Versos, C. A. M. (2011) A comparative analysis of six bionic design methods, International Journal of Design Engineering 4 (2), 114-131.

[23] Carlos A. M. Versos and Denis A. Coelho,(2013), A Bi-Directional Method for Bionic Design with Examples

[24]Hilma Raimona Zadry, Prima Fithri, Utari Triyanti and Difana Meilani, (2017), Department of Industrial Engineering, Faculty of Engineering, University of Andalas, Padang, West Sumatera, Indonesia, AN ERGONOMIC EVALUATION OF MOUNTAINEERING BACKPACKS VOL. 12, NO. 18, SEPTEMBER 2017 ISSN 1819-6608ARPN Journal of Engineering and Applied Sciences

[25] K. Rose, A. Davies, M. Pitt, D. Ratnasinghe, and L.D'Argenzio, (2016) "Backpack palsy: A rare complication of backpack use in children and young adults-A new case report," Eur J Paediatr Neurol., Vol. 20(5), pp. 750-753

[26] M. Pau, S. Mandaresu, B. Leban, and M. A. Nussbaum,(2015), "Short-term effects of backpack carriage on plantar pressure and gait in schoolchildren," J Electromyogr Kinesiol., Vol. 25(2), pp. 406-412,

[27] A.J.F. de Paula, J.C.P. Silva, J.C.R.P. Silva,(2015), "The Influence of Load Imposed by the Backpack School in Children and Teens in Brazil," Procedia Manufacturing, Vol. 3, pp. 53505357.

[28] M. Z. Ramadan and A. M. Al-Shayea, (2013) "A modified backpack design for male school children," Int J Ind Ergon, Vol. 43(5), pp. 462-471. 
[29] C. Devroey, I. Jonkers, A. De Becker, G. Lenaerts, and A. Spaepen, (2007), "Evaluation of the effect of backpack load and position during standing and walking using biomechanical, physiological and subjective measures," Ergonomics, Vol. 50(5), pp.728-742.

[30] B. Lobb, (2004) "Load carriage for fun: a survey of New Zealand trampers, their activities and injuries," Appl ergon, Vol. 35(6), pp. 541-547.

[31] G. I. Sheir-Neiss, R. W. Kruse, T. Rahman, L. P. Jacobson, and J. A. Pelli, (2003), "The association of backpack use and back pain in adolescents," Spine, Vol. 28(9), pp. 922-930. [32] Y. T. Wang, D. D. Pascoe, and W. Weimar, (2001), "Evaluation of book backpack load during walking," Ergonomics, Vol. 44(9), pp. 858-869.

[33] K. D. Dahl, H. Wang, J. K. Popp, and D. C. Dickin,(2016), "Load distribution and postural changes in young adults when wearing a traditional backpack versus the BackTpack," Gait \& Posture, Vol. 45, pp.90-96.

[34] H. W., S. J. Legg, J. Beadle, and D. Hedderley, (2003) "Comparison of four different backpacks intended for school use," Appl Ergon, Vol. 34(3), pp. 257-264.

[35] D. Retnari, A. Velahyati, and Hartati, (2011), "Desain Backpack Berdasarkan Analisis Biomekanika dengan Pendekatan QFD dan TRIZ untuk Pendaki Wanita," Hasil Penelitian Fakultas Teknik, Grup Teknik Mesin, universitas Hasanuddin, Vol. 5, pp. 1-12.

[36] U.S. Department of Labor Occupational Safety and Health Administration,(2000), Introduction to Ergonomics - OSHAcademy Course 711 Study Guide [37] https://www.deuter.com/DE/en/advice.html

[38](2006), Carrying Backpacks: Physical Effects Illinois State Board of Education [39] Taylor \& Francis Group, LLC ,(2010), Materials and Manufacturing Processes, 25: 281286 ,

[40]https://www.theverge.com/2018/9/5/17815136/vertepac-backpack-review-xtr-35-18 [40]https://www.theverge.com/2018/9/5/17815136/vertepac-backpack-review-xtr-35-18 [42]https://www.nbcnews.com/mach/innovation/robotic-exoskeletons-are-changing-livessurprising-ways-n722676 
ПРИЛОГ А

\section{AHКЕТА ЗА ИЗБОР НА РАНЕЦ}

Bозраст:
А) Под 18години
Б) $18-29$ години

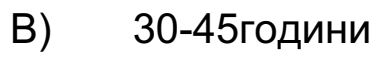
г) Над 45години

Пол: м / ж

Висина: $\mathrm{cm}$

Дали сте член на планинарско друштво: ДА / $\mathrm{HE}$

1. Колку пари би потрошиле за добар ранец за планинарење?
А) Помалку од 3000ден.
Б) Од 3000-6000ден.
В) Од 6000-12000ден
Г) Повеќе од 12000ден.

2. Колку често користите ранец за некакво патување/планинарење?
А) Неделно пат/и
Б) Месечно пат/и
В) Годишно пат/и
Г) Не користам ранец

3. Колку долго трајат патувањата со Вашиот ранец?
А) 1 ден
Б) Викенд
В) 5 дена
г) Повеќе од 5 дена

4. Какви терени преферирате за патување? 

А) Рамни (урбани)
Б) Лесно пристапни терени
В) Тешко пристапни терени
Г) Алпинизам

5. Која големина е Вашиот ранец за патување?
А) Помал од 50литри
Б) $50 Л и т р и$

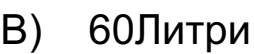
г) Повеќе од 60Литри

6. При купување на нов ранец колку е важно за ВАС:

(Пополнете со вредности од 1-5, со тоа што 5 е многу важно, а 1 е неважно)
ИЗДРЖЛИВОСт :
$\begin{array}{lllll}1 & 2 & 3 & 4 & 5\end{array}$
ГОЛЕМ БРОЈ НА ПРЕГРАДИ И ЏЕПОВИ:
$\begin{array}{lllll}1 & 2 & 3 & 4 & 5\end{array}$
ИЗГЛЕД:
$\begin{array}{lllll}1 & 2 & 3 & 4 & 5\end{array}$
ЕРГОНОМСКИ/ АНАТОМСКИ ЗАДЕН ДЕЛ:
$\begin{array}{lllll}1 & 2 & 3 & 4 & 5\end{array}$
ВИСОКО ТЕХНОЛОШКИ:
$\begin{array}{lllll}1 & 2 & 3 & 4 & 5\end{array}$
водООтПОРНОСт:
$\begin{array}{lllll}1 & 2 & 3 & 4 & 5\end{array}$
НОСИВОст:
$\begin{array}{lllll}1 & 2 & 3 & 4 & 5\end{array}$
ТЕЖИНА:
$\begin{array}{lllll}1 & 2 & 3 & 4 & 5\end{array}$

7. Колку брзо и ефикасно наоѓaте што Ви е потребно во ранецот?
А) Брзо и лесно
Б) Повеќето пати брзо и лесно
В) Повеќе пати тешко и бавно
Г) Секогаш тешко и бавно

8. Колку добро се спакувани (организирани) Вашите работи во ранецот?

А) Секогаш добро и уредно организирани 
Б) Повеќето пати добро организирани

В) Повеќетопати неорганизирани

Г) Секогаш неорганизирани

9. Наведете кои се најчестите проблеми кои ги имат при користење на Вашиот ранец?

10. Каков тип на ранец преферирате?
А) Со Внатрешна рамка
Б) со Надворешна рамка

11.Дали ранецот за планинарење го користите и за други намени?
А) ДА
Б) $\mathrm{HE}$ 